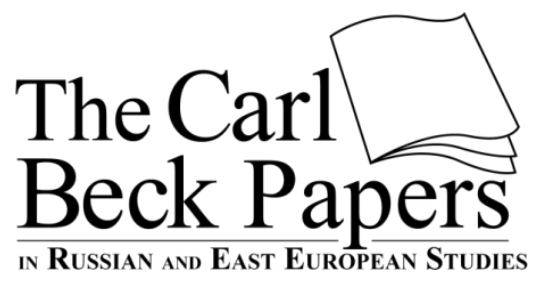

Number 2503
Daniel E. Miller

The Influence of Václav Klaus on Czech Public Opinion Regarding the European Union

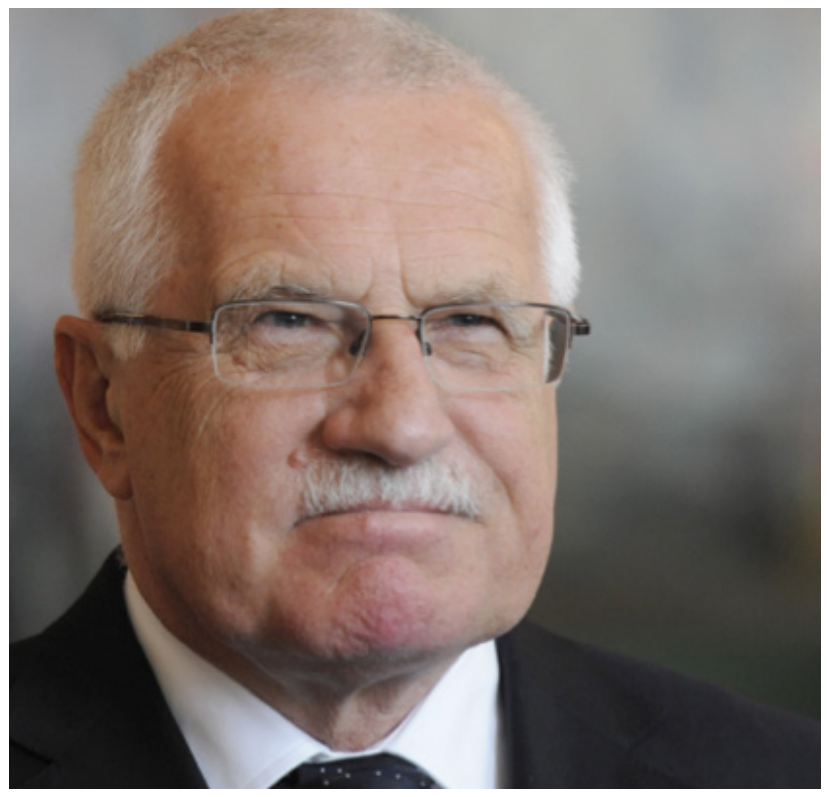




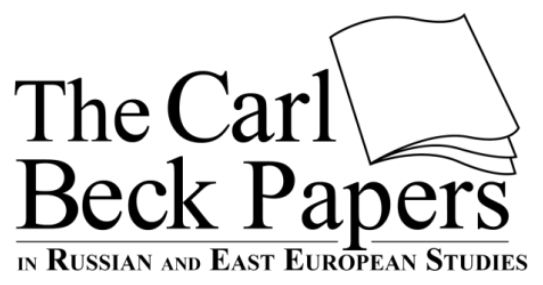

Number 2503

ISSN: 2163-839X (online)

Daniel E. Miller

\section{The Influence of Václav Klaus on Czech Public Opinion Regarding the European Union}

\section{(cc) $\mathrm{BY}-\mathrm{NC}-\mathrm{ND}$}

This work is licensed under a Creative Commons Attribution-Noncommercial-No Derivative Works 3.0 United States License.
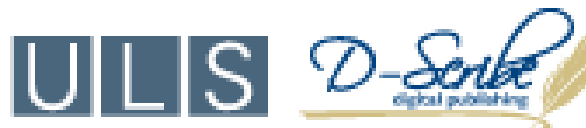

This site is published by the University Library System of the University of Pittsburgh as part of its D-Scribe Digital Publishing Program, and is cosponsored by the University of Pittsburgh Press. 
Daniel E. Miller is a professor of history at the University of West Florida in Pensacola, Florida, USA. He is the author of Forging Political Compromise: Antonin Švehla and the Czechoslovak Republican Party (1918-1933), which also appears in Czech, and is one of the coeditors of $K$ úloze a významu agrárního hnutív českých a československých dějinách. He is the author of 13 articles and chapters, in Czech and English, and the coauthor of one article. Miller currently is coauthoring a book about consociational democracy in Central Europe and is writing a monograph on the creation of new agricultural settlements as part of the Czechoslovak land reform between the world wars. His teaching interests include East-Central Europe and Modern Europe.

Cover Photograph: Václav Klaus, courtesy of Institut Václava Klause.

No. 2503, May 2017

2017 by The Center for Russian and East European Studies, a program of the University Center for International Studies, University of Pittsburgh

ISSN 2163-839X (online)

\section{The Carl Beck Papers}

Publisher: University Library System, University of Pittsburgh

Editors: William Chase, Bob Donnorummo

Managing Editor: Zsuzsánna Magdó

Editor Emeritus: Ronald H. Linden

For 34 years, The Carl Beck Papers in Russian and East European Studies, named after the first director of the University Center for International Studies, published hundreds of monographlength articles presenting innovative research by scholars focused on East Europe, the USSR and the Soviet successor states. At the end of 2015, the Carl Beck Papers ceased accepting new submissions. However, the entire digital collection of The Carl Beck Papers is now available free of charge, thus providing scholars from around the world with access to a large repository of high-quality, peer reviewed research on a broad range of topics related to the region. The fully searchable archive is available at: carlbeckpapers.pitt.edu/ojs/index.php/cbp/issue/archive. 
While president of the Czech Republic between 2003 and 2013, Václav Klaus, an outspoken critic of the European Union, employed speeches, interviews, and writings in his efforts to discredit the EU in the eyes of Czech citizens. Miller used opinion polls from Eurobarometer and the Public Opinion Research Center (CVVM), of the Czech Academy of Sciences, to establish a correlation between Klaus's popularity and Euroskepticism. In the early years of Klaus's presidency, skepticism about the EU among Czechs grew, and between 2006 and 2010, there was a strong correlation between Klaus's popularity and Czech Euroskepticism. As Klaus's popularity waned, during his last years in office, Czech confidence in the EU began to rise. This study not only helps to explain some bases of Czech Euroskepticism, but it also addresses the influence Czech presidents have in shaping public opinion in their country. 


\section{The Influence of Václav Klaus on Czech Public Opinion Regarding the European Union}

\section{The Czech Republic in the Context of EU Public Opinion}

After the fall of communism in 1989, the Czechs were extremely optimistic about their economic future. They expected to have little difficulty joining the European Union and assumed that the Slovaks, with their less robust economy, would face delays. In fact, on May 1, 2004, the two countries entered the EU together, along with eight other states. In the autumn of that year, Czechs and Slovaks participated in their first Standard Eurobarometer (SE) survey, which the European Commission undertakes semiannually. The results showed that the citizens of both states, then with separate countries for a little more than a decade, put great faith in the EU. The number of Czechs (52 percent) and Slovaks (60 percent) who trusted the EU far outstripped those who did not, and the two ethnic groups were more trusting of the EU than Europeans as a whole (the EU average was 50 percent). ${ }^{1}$ When asked about the image they had of the EU, a plurality of Czechs and Slovaks responded positively, although the results were lower than the EU average. ${ }^{2}$

Within a few years, the Czechs became far more skeptical of the EU, not only with respect to the majority of EU inhabitants but also but also in comparison to Slovaks. A 2006 Eurobarometer survey examined the perceptions of how the EU might affect individuals' lives in the decade to follow. The countries that were optimistic included Slovakia, while the Czech Republic was among those countries exhibiting widespread pessimism. ${ }^{3}$ At roughly the same time, another Eurobarometer study showed that the perceptions of Czechs about the economy were generally more optimistic than those of the Slovaks. Compared to five years before, the Czechs were more hopeful than Slovaks about their current and future quality of life, their lives in general, their current financial situation, their country's economy and job market, and their current economic situation; however, expectations for a better economic future were greater among Slovaks (41 percent) than Czechs (34 percent). ${ }^{4}$ Ironically, the Czechs outperformed the Slovaks, in terms of 2006 GDP purchasing power standards (PPS), with an index of 81 as opposed to 62 (the PPS of the 28 EU member states totaled 100). ${ }^{5}$ The Czech GDP was the highest on record since the end of Communist rule, growing 6.9 percent in 2006, after having risen 6.4 percent in 2005, but Slovakia saw its 2006 GDP expand by 8.5 percent, from a 6.4 percent increase the previous year. ${ }^{6}$ Perhaps the Czechs, upon viewing the success of their former Slovak countrymen, felt the pangs of relative deprivation.

In the spring 2013 Eurobarometer poll of EU members, the Czech Republic ranked as the most Euroskeptic of those states not facing economic crises: 56 percent of the respondents were pessimistic about the future of the EU. ${ }^{7}$ The UK ranked second in Euroskepticism, with 54 percent of those polled being pessimistic. In stark contrast to the Czechs, 54 percent of the Slovaks were optimistic about the EU. Trust is another measure of Euroskepticism. Of the states not facing economic crises, the UK had the highest number of respondents-68 percent-who did not trust the EU. Distrust in Germany was at 61 percent; in the Czech Republic, it was at 60 percent, the same as the EU average. Conversely, only 50 percent of the Slovaks tended not to trust the EU. ${ }^{8}$ Finally, when asked, in the spring of 2013, if the EU elicits a positive, neutral, or negative image, those Czechs who viewed it negatively were at 36 percent, once more not far behind 43 percent of the respondents in the UK. On this issue, Slovaks and Czechs again were reversed: 25 percent of the Czechs and 34 percent of the Slovaks saw the EU as positive, while 36 percent of the Czechs and 26 percent of the Slovaks saw the EU as negative. On the whole, 29 percent of those in the EU had a negative opinion of the EU, and 30 percent had a positive opinion. ${ }^{9}$

$-1-$

The Carl Beck Papers in Russian and East European Studies http://carlbeckpapers.pitt.edu | DOI 10.5195/cbp.2017.219| Number 2503 


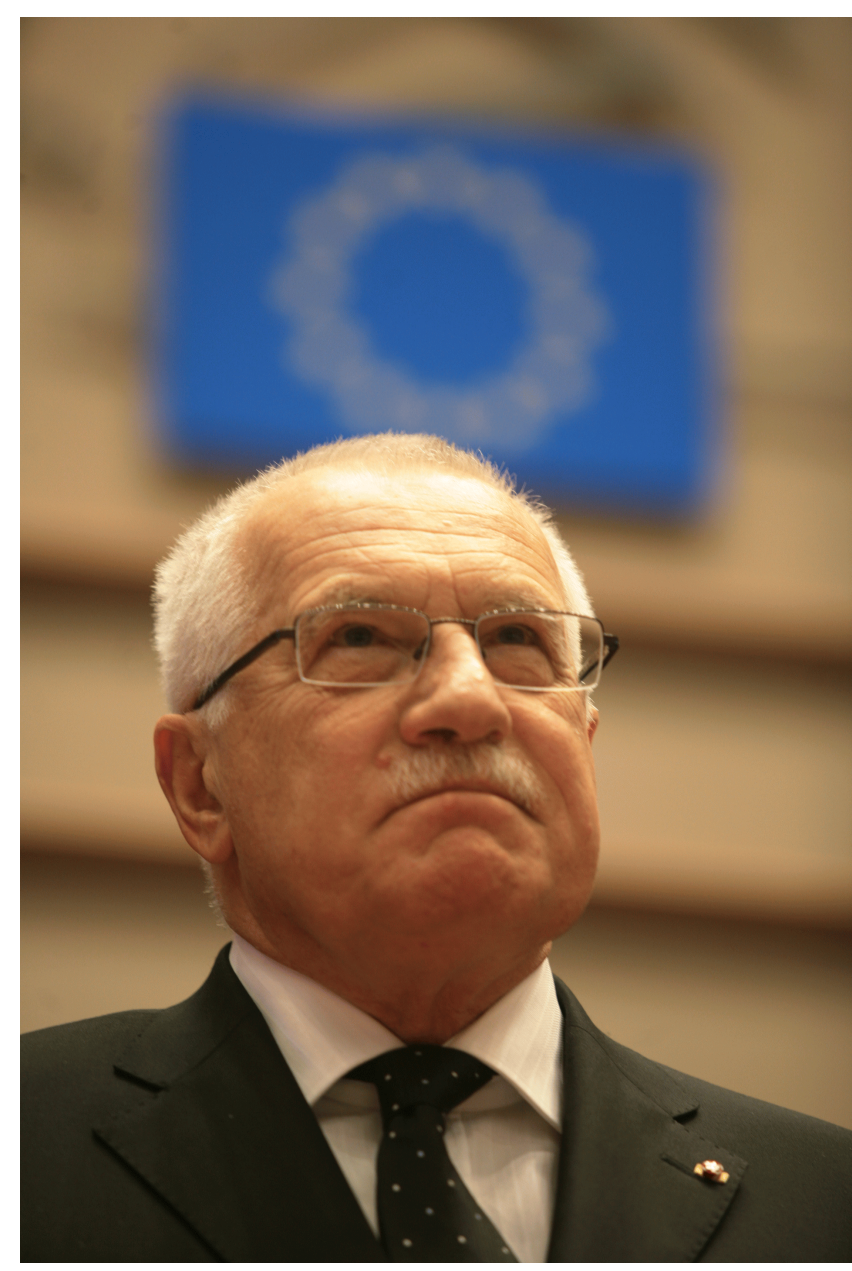

Václav Klaus addressing the European Parliament, 19 February 2009. Photo: Institut Václava Klause.
Denmark long had the popular reputation of being the most Euroskeptic state in the EU, largely because the Danes oppose specific features of the EU, yet 72 percent of the Danish respondents, in the spring 2013 SE, were positive about the EU's future. ${ }^{10}$ Excluding the member states that faced economic crises during the Great Recession, the United Kingdom was another leader in Euroskepticism, and the Czech Republic was right behind. The loss of faith the Czechs had in the EU is puzzling, given not only their optimism in 2004 but also their generally favorable economic performance and the sustained positive attitude toward the EU of the Slovaks, who had shared a common state with the Czechs, between 1918 and 1939 and again from 1945 to 1989 , for a total of 65 years.

\section{The Possibility of Presidential Influence}

Anecdotal evidence provides some plausible explanations for Czech Euroskepticism. EU membership brought benefits for the Czechs, but many decry the added layer of bureaucracy Brussels generates and the multitude of economic regulations that originate with the EU. ${ }^{11}$ Czechs did not expect an economic miracle upon entering the EU, but membership did not result in noticeable gains. In fact, for some time, many complained that the open borders merely allowed the Germans to shop in the Czech Republic, where the prices were cheaper, causing higher prices for Czechs. Later, however, the situation reversed. Another explanation for the Czech hesitancy to embrace the EU with more enthusiasm may be Czech political culture, which because of their experience as part of the Habsburg Monarchy, the Third Reich of Nazi Germany, and the Soviet Bloc, Czechs are highly suspicious of supranational authority. ${ }^{12}$ One also cannot discount the influence Euroskepticism throughout Europe had on the Czechs' incredulous attitude about the EU, as is apparent in the parallel trends in Figures 1, 2, and 3.

While these and other factors may have contributed to the Czechs' lack of enthusiasm for the EU during much of the first and into the second decade of the twenty-first century, another factor may have been the Euroskepticism of Václav Klaus (born 1941). An economist and politician, Klaus had become president of the Czech Republic on March 7, 2003, just 14 months before the country entered the EU. A decade later, on March 7, 2013, after two terms as president, he left office. ${ }^{13}$ Throughout his entire tenure as president, Klaus was highly critical of the EU, in his speeches, interviews, and writings, and he may have shaped Czech thinking about the EU. Even though the Czech Republic does not have a strong presidency, it has a tradition, established with the founding of Czechoslovakia, of presidents with high intellectual and moral standards. This includes the professor-turned-politician Tomáš G. Masaryk (1850-1937), who was president from 1918 until 1935; his onetime student, Edvard Beneš (1884-1948), president in 1935-1939, 1940-1945 (in exile), and 1945-1948; and the former dissident and playwright Václav Havel (1936-2011), who was president of Czechoslovakia from 1989 to1992 and of the Czech Republic from 1993 to 2003. Czech Euroskepticism has many roots, and the Czech Republic, like any state in the EU, is bound to have its share of those who view the EU with consternation. The 
strength of Czech Euroskepticism, however, may have grown as a result of the vehement Euroskepticism of Klaus, who used the bully pulpit of the Czech presidency to sway his fellow citizens' opinions against the EU. ${ }^{14}$ Klaus had a long history of consistent opposition to the EU, but he referred to himself as a Eurorealist, supposedly because he acknowledged some positive results from the development of the EU, but the same can be said of many Euroskeptics. ${ }^{15}$ It is likely that he also preferred the Eurorealist label because it may not have alienated potential supporters who looked favorably on the EU. In reality, his position as a Euroskeptic is firm, and he once stated, "My critical opinions about certain things in the European Union are constants of my life." 16 The only question is the degree of Klaus's Euroskepticism. In simplistic terms, hard Euroskeptics object to the very idea of a united Europe; soft Euroskeptics take exception to specific policies and may change their views. ${ }^{17}$ At first glance, Klaus has been a hard Euroskeptic, although Vít Hloušek and Petr Kaniok argue that he displayed elements of both hard and soft Euroskepticism. ${ }^{18}$ Klaus's suggestions for changing the EU, such as reversing its course of integration and starting a new European organization, along with his contention that the euro was an ill-conceived notion, disguised the depth of his Euroskepticism and were impossible to implement without dismantling much of the EU. Klaus's true sentiments only appeared after he left the presidency, when he called for the Czech Republic to withdraw from the EU. Hloušek and Kaniok were correct to identify both hard and soft trends in Klaus's Euroskepticism, but the soft edges of Klaus's beliefs existed only to disguise his real motives.

Klaus's stance against the EU emerged well before he became president of the republic. He established the Civic Democratic party (Občanská demokratická strana, ODS) in 1991, and he influenced the Euroskeptical stance reflected in the party's programs. ${ }^{19}$ Although Klaus, as prime minister from 1993 to 1998, negotiated the entry of the Czech Republic into the EU, he remained critical of Brussels. ${ }^{20}$ At the 1995 World Economic Forum in Davos, Switzerland, Klaus disparaged the EU subsidy policy, challenging Hans van der Broek (born 1936), the Dutch EU commissioner responsible for the countries seeking EU accession. Klaus and van der Broek had sparred verbally before, and Klaus's remarks this time were so sharp that van der Broek asked, "Is the Czech Republic joining the European Union, or does the European Union want to become part of the Czech Republic?"21 In 2001, while serving as chair of the Chamber of Deputies, Klaus published Evropa pohledem politika, pohledem ekonoma (Europe in the View of a Politician and in the View of an Economist), a compilation of his speeches and writings, delivered or published between June 1993 and April 2001, about the EU, the euro, and the basis for his Euroskepticism. ${ }^{22}$ In December 2001, Klaus visited Brussels with a delegation representing the Czech Republic as a candidate for EU membership. Upon returning, he explained to the Chamber of Deputies the position he had taken in Brussels, a speech that provides further insight into Klaus's Euroskepticism. For example, Klaus believed the principle contained in the Maastricht Treaty that Europe should move "from intergovernmentalism to supranationalism" was a mistake that should be reversed. He thought that the EU should respect the sovereignty of the individual states and their legislatures and that the creeping unification of the continent must cease. ${ }^{23}$ During interviews in 2001 with Petr Hájek (born 1951), who became Klaus's press secretary, Klaus claimed that an EU constitution meant "Orwellian European unification." "I always thought that he who arrives with a European constitution is from the devil," he told Hájek. ${ }^{24}$ Klaus also feared that Prague would become an "intermediate stop" between the country's regions, that is, the Czech members of the EU's Committee of Regions, and the Eurocrats in Brussels. ${ }^{25}$ When the Czech Parliament, voting on its third ballot, narrowly elected him president in February 2003, Klaus continued his barrage against the EU. ${ }^{26}$ In June 2003, three months after he had assumed the presidency, the Czechs conducted a referendum about joining the EU. Klaus took no public stance on the question, perhaps because he recognized that his opposition to the EU was unpopular. As he stated in January 2001, 
unfortunately, membership or nonmembership in [the] EU has become a differentiating factor suggesting who is and who is not a "normal, standard (or standardized), mature, obedient European" country. Despite the fact that it is unfair, for me difficult to swallow, it has been widely accepted. Because of that, we have no other alternative than to make a maximum effort to become members as soon as possible-regardless [of] our views about the currently realized model of European unification and about [the] ideology behind it. ${ }^{27}$

In the referendum, 77 percent of the Czechs voted for accession. Afterward, Klaus openly and persistently criticized the EU, which may have contributed to the deterioration of support for the EU.

The Czechs held both Klaus and his predecessor, Havel, in high regard. Given the Czechs' criticisms of Klaus in their private conversations and their jokes about his controversial stances on global warming, homosexuality, and the EU, one might expect that the results of opinion polls about Klaus's handling of the presidency would be dramatically lower than for Havel, a highly respected humanitarian, former dissident, intellectual, and politician. Nevertheless, in the polling about their performance, under the auspices of the Public Opinion Research Center (Centrum pro výzkum veřejného mínění, CVVM), a branch of the Czech Academy of Sciences, the differences are not so great, aside from one category. Klaus and Havel stood a mere one to three percentage points apart, with Havel always in the lead, regarding their contact with the population and their understanding of its problems (Havel, 23 percent; Klaus, 21 percent), their influence on internal political life (Havel, 40 percent; Klaus, 39 percent), and their ability to ensure the seriousness and dignity of the office of president (Havel, 64 percent; Klaus, 67 percent). There was a small difference, again with Havel in the lead, in their authority with the citizens (Havel, 45 percent; Klaus, 40 percent) and their ability to perform their constitutional duties (Havel, 64 percent; Klaus, 60 percent). Klaus only was vulnerable with respect to his ability to represent the Czech Republic abroad. Havel received an extremely high score in this area-82 percent. Klaus garnered only 54 percent. ${ }^{28}$

Klaus's high esteem among Czechs gave traction to his message of Euroskepticism. According to the opinion polls that CVVM conducted at least twice each year, Klaus's popularity before his election as president was on a par with other politicians, but after March 2003, his prestige soared (see Table 1). Klaus became by far the most popular politician in the Czech Republic until the end of his presidency. His highest rating was 73 percent in March 2007. Otherwise, his rating did not drop below 55 percent until September 2011, when it fell to 51 percent. In 2012, his ratings were 49 percent in March and 51 percent in December, just months before his tenure in office expired. From March 4 to March 11, 2013, when CVVM conducted its spring public opinion survey, Klaus received only 27 percent, but this occurred during the time when he had taken a number of unpopular stances and his term was about to expire. The new president, Miloš Zeman (born 1944), took office on March 8, and his rating was 51 percent. Ironically, since it appeared that Zeman's political career had ended, CVVM did not include him in the ratings of selected politicians in preceding years. ${ }^{29}$

Klaus's decline and Zeman's rise in popularity is further evidence to suggest that the Czech population holds its president, who is to be above day-to-day politics, in high regard, thus increasing the weight of the president's opinions. Nevertheless, since he took office, Zeman's popularity was markedly lower than Klaus had experienced as president. ${ }^{30}$ Perceptions may have changed because Zeman was the first president to attain office through a popular vote, which may make the person who holds the post more vulnerable to public opinion than their pre-2013 predecessors, whom the Chamber of Deputies and Senate had elected. Another possibility is that Zeman's scores may have been lower because he was embarrassingly controversial. For example, he occasionally appeared to be inebriated in public, denied the ill-effects of smoking when giving advice to children, was vulgar during a presidential radio address, and supported Russia's stance with respect to Crimea and southeastern Ukraine. 
Table 1

The Monthly and Semiannual Popularity Ratings of Václav Klaus as President (percent)

\begin{tabular}{|l|c|c|c|c|c|c|c|c|c|c|c|c|}
\hline \multicolumn{1}{|c|}{ Month } & $\mathbf{2 0 0 2}$ & $\mathbf{2 0 0 3}$ & $\mathbf{2 0 0 4}$ & $\mathbf{2 0 0 5}$ & $\mathbf{2 0 0 6}$ & $\mathbf{2 0 0 7}$ & $\mathbf{2 0 0 8}$ & $\mathbf{2 0 0 9}$ & $\mathbf{2 0 1 0}$ & $\mathbf{2 0 1 1}$ & $\mathbf{2 0 1 2}$ & $\mathbf{2 0 1 3}$ \\
\hline January & -- & 35 & 69 & 64 & -- & -- & -- & -- & -- & -- & -- & -- \\
\hline February & -- & -- & -- & -- & 68 & 73 & -- & 63 & -- & -- & -- & -- \\
\hline March & 33 & -- & -- & -- & 64 & -- & -- & -- & -- & 62 & 49 & 27 \\
\hline April & -- & 60 & -- & -- & -- & -- & -- & -- & 68 & -- & -- & -- \\
\hline May & -- & -- & 70 & 63 & 66 & 68 & 58 & -- & -- & -- & -- & -- \\
\hline June & -- & -- & -- & -- & -- & -- & -- & -- & -- & -- & -- & -- \\
\hline July & -- & -- & -- & -- & -- & -- & -- & -- & -- & -- & -- & -- \\
\hline August & -- & -- & -- & -- & -- & -- & -- & -- & -- & -- & -- & -- \\
\hline September & 21 & -- & 68 & -- & -- & 66 & -- & 59 & 68 & 51 & -- & 24 \\
\hline October & -- & 55 & -- & 65 & -- & -- & 60 & -- & -- & -- & -- & -- \\
\hline November & 30 & -- & -- & -- & -- & -- & -- & -- & -- & -- & -- & -- \\
\hline December & -- & -- & -- & -- & -- & 64 & 55 & -- & 65 & -- & 51 & -- \\
\hline First Six Months ${ }^{1}$ & 33.0 & 47.5 & 69.5 & 63.5 & 66.0 & 70.5 & 58.0 & 63.0 & 68.0 & 62.0 & 49.0 & 27.0 \\
\hline Second Six Months ${ }^{2}$ & 26.0 & 55.0 & 69.0 & 65.0 & 69.5 & 65.0 & 57.6 & 59.0 & 66.5 & 51.0 & 51.0 & 24.0 \\
\hline
\end{tabular}

${ }^{1}$ The percentages in this row reflect the arithmetic mean of the percentages for the first six months of each year.

${ }^{2}$ The percentages in this row reflect the arithmetic mean of the percentages for the second six months of each year.

${ }^{3} \mathrm{CVVM}$ did not survey presidential popularity in the second half of 2006, so the percentage here is an average of the May 2006 and the February 2007 percentages.

Source: Centrum pro výzkum veřejného mínění, Sociologický ústav AV ČR, v.v.i., "Důvěra vybraným politikům," June 23, 2004, May 29, 2007, January 7, 2008, March 30, 2011, and October 1, 2013, table 1 in each case, http://cvvm.soc.cas.cz/. Klaus did not appear in "Důvěra vrcholným politikům-záríi 2014," for March, May, and September 2014, http://www.parlamentnilisty.cz/profily-sprava/user-data/06B091AE/file/67714-CVVM_duvera_ vrcholnym \%20politikum.pdf. 
Table 2

The Monthly and Semiannual Confidence Ratings of Václav Klaus as President (percent)

\begin{tabular}{|l|c|c|c|c|c|c|c|c|c|c|c|}
\hline \multicolumn{1}{|c|}{ Month } & $\mathbf{2 0 0 3}$ & $\mathbf{2 0 0 4}$ & $\mathbf{2 0 0 5}$ & $\mathbf{2 0 0 6}$ & $\mathbf{2 0 0 7}$ & $\mathbf{2 0 0 8}$ & $\mathbf{2 0 0 9}$ & $\mathbf{2 0 1 0}$ & $\mathbf{2 0 1 1}$ & $\mathbf{2 0 1 2}$ & $\mathbf{2 0 1 3}$ \\
\hline January & -- & 72 & 71 & 69 & 72 & 58 & 65 & 68 & 69 & 57 & 26 \\
\hline February & -- & 71 & 71 & 74 & 76 & 58 & 67 & 69 & 65 & 56 & -- \\
\hline March & -- & 77 & 69 & 68 & 73 & 64 & 65 & 66 & 67 & 53 & 27 \\
\hline April & 64 & 72 & 67 & 73 & 74 & 63 & 65 & 74 & 68 & 47 & -- \\
\hline May & 69 & 77 & 71 & 71 & 71 & 63 & 61 & 67 & 59 & 49 & -- \\
\hline June & 63 & 74 & 72 & -- & 71 & 62 & 66 & -- & 55 & 51 & -- \\
\hline July & -- & -- & -- & -- & -- & -- & -- & -- & -- & -- & -- \\
\hline August & -- & -- & -- & -- & -- & -- & 54 & -- & -- & -- & -- \\
\hline September & 61 & 75 & 71 & 74 & -- & 67 & $63 / 61^{3}$ & 72 & 54 & 52 & -- \\
\hline October & 64 & 73 & 71 & 74 & 66 & 65 & -- & 64 & 57 & 50 & -- \\
\hline November & 66 & 73 & 69 & 70 & 66 & 63 & 61 & 70 & 57 & 55 & -- \\
\hline December & 66 & 72 & 69 & 73 & 66 & 60 & 68 & 70 & 58 & 53 & -- \\
\hline First Six Months ${ }^{1}$ & 65.3 & 73.8 & 70.2 & 71.0 & 72.8 & 61.3 & 64.8 & 68.8 & 63.8 & 52.2 & 26.5 \\
\hline Second Six Months ${ }^{2}$ & 64.3 & 73.3 & 70.0 & 72.8 & 66.0 & 63.8 & 61.4 & 69.0 & 56.5 & 52.5 & -- \\
\hline
\end{tabular}

${ }^{1}$ The percentages in this row reflect the arithmetic mean of the percentages for the first six months of each year.

${ }^{2}$ The percentages in this row reflect the arithmetic mean of the percentages for the second six months of each year. ${ }^{3}$ CVVM conducted a second survey in September 2009, after the Constitutional Court had cancelled early elections.

Source: Centrum pro výzkum veřejného mínění, Sociologický ústav AV ČR, v.v.i., "Důvěra k ústavním institucím," January 14, 2004; "Důvěra k ústavním institucím a spokojenost s politickou situací," December 17, 2004, December 23, 2005, December 20, 2006, January 7, 2008; "Důvěra ústavním [sic.] institucím a spokojenost s politickou situací," December 22, 2008, September 21, 2009, October 12, 2009, November 23, 2009, December 1, 2010, January 2, 2012; and "Důvěra ústavním [sic.] institucím," January 3, 2013 (mistakenly dated 2012), February 5, 2013 (mistakenly dated 2012), and April 29, 2013, table 1 in each case, http://cvvm.soc.cas.cz/.

$-6-$ 
The CVVM conducted another poll, nine or ten months out of each year, to determine the trust or confidence Czechs had in their official institutions, including the presidency (see Table 2). Although this study will refer to the CVVM poll on the president's popularity, it relies most on the CVVM survey about trust or confidence in the presidency, which was more frequent, therefore yielding more dependable results. Trust in the presidency increased slightly in Klaus's second year in office, and percentages averaged in the low 70s until the autumn of 2007, when they decreased to an average of 66 percent. In 2008 and 2009, they were in the low and middle $60 \mathrm{~s}$; in 2010, they were in the high 60s. They dropped to the low 60s in the spring of 2011, and then were in the middle 50s in the autumn. In 2012, they were in the low 50s, and in the spring of 2013, as Klaus was about to leave office, they reached a low of 26.5 percent.

\section{Quantifying Czech Euroskepticism}

No opinion poll exists that directly targets the influence Klaus had on the perceptions of the Czech public of the EU. As a result, researchers must rely on the CVVM polls that gauge the popularity and confidence of Czech presidents, in combination with SE polls that assess Czech attitudes toward the EU. The SE surveys, which take place in all EU member states in the spring and autumn of each year, provide an objective data base for public opinion on a wide range of issues, and they are useful for long-term research (Table 3). ${ }^{31}$ They do not ask specifically about Euroskepticism, which is too broad of a tendency to ascertain accurately with a direct question. Instead, three SE questions provide a general indication of Euroskepticism by determining whether the respondents trust the EU, whether they have a positive or negative view of the EU, and whether they agree with the direction in which the EU is going (see Table 4).

From the second year of Klaus's presidency (2004) until he left office, Czech willingness to trust the EU was always higher than the EU average, aside from spring 2012 (see Table 5 and Figure 1). Nevertheless, from 2004 through 2010, the average percentage of distrust throughout Europe for the EU was higher than among Czechs, apart from the spring of 2007, when it was the same. From the spring of 2011 until the autumn of 2014, however, Czech distrust was the same or higher than distrust throughout the EU. These same statistics show that the Czechs' tendency to distrust the EU gradually replaced the willingness to trust it. More Czechs trusted than distrusted the EU in 2004, and both percentages rose in the following two to three years, while the number of undecided respondents fell. Trust reached its peak of 62 percent in the spring of 2006, then it exhibited an overall downward trend that lasted eight years. Between 2004 and 2008, distrust generally hovered in the low 30s, although it spiked to 38 percent in the second half of 2005, while it dipped to 20 percent in the spring of 2006. After five years of Czech membership in the EU, perceptions changed. In the spring of 2009, distrust jumped seven points, to 40 percent, while the percentage of undecided respondents descended to a historical low. Distrust dropped in the autumn of 2009, but it rose more or less steadily afterward. In the spring of 2011, for the first time, more people distrusted the EU than trusted it, and in the spring of 2012, distrust peaked at 63 percent. The autumn of 2012 brought another shift in perceptions. In the second half of 2012 and the first half of 2013, trust slowly increased, decreased in the second half of 2013 and the first half of 2014, and soared in the second half of 2014. In the same period, distrust declined slightly (to 60 percent) in the autumn of 2012, then it held steady in the spring of 2013. Distrust crept up by 1 percent in the autumn of 2013 and stayed at 61 percent through the first half of 2014. Then, in the second half of 2014, distrust plunged 13 percentage points.

Table 6 and Figure 2 show trends in the image the Czechs and EU citizens had of the EU. In the spring of 2004, negativity among Czechs was at 39 percent, the highest percentage in the period under consideration. It plummeted to 20 percent by the autumn of 2004 and hovered between 16 and 21 percent until the spring of 2010, when it jumped to 25 percent. In the survey of autumn 2010, it slumped to 23 percent and then climbed, in subsequent surveys, to a high, in spring 2013, of 36 percent. Aside from autumn 2005, when the EU and Czech percentage both stood at 20 percent, Czech negativity toward the EU was higher than the EU average.

$$
-7-
$$

The Carl Beck Papers in Russian and East European Studies http://carlbeckpapers.pitt.edu | DOI 10.5195/cbp.2017.219 | Number 2503 
Table 3

Standard Eurobarometer Surveys

\begin{tabular}{|l|l|l|}
\hline Number & \multicolumn{1}{|c|}{$\begin{array}{c}\text { Date of Fieldwork } \\
\text { in the Czech Republic }\end{array}$} & \multicolumn{1}{c|}{ Date of Publication $^{2}$} \\
\hline $2016 / 85$ & May 21-30, 2016 & July 2016 ("First Results") \\
\hline $2015 / 84$ & November 7-17, 2015 & December 2015 (“Annex") \\
\hline $2015 / 83$ & May 16-27, 2015 & July 2015 (“Annex") \\
\hline $2014 / 82$ & November 8-17, 2014 & December 2014 ("First Results") \\
\hline $2014 / 81$ & May 31-June 9, 2014 & July 2014 ("First Results") \\
\hline $2013 / 80$ & November 2-13, 2013 & December 2013 ("First Results") \\
\hline $2013 / 79$ & May 11-24, 2013 & July 2013 ("First Results") \\
\hline $2012 / 78$ & November 3-14, 2012 & December 2012 ("First Results") \\
\hline $2012 / 77$ & May 12-24, 2012 & July 2012 \\
\hline $2011 / 76$ & November 15-20, 2011 & March 2012 (“Aggregate Report") \\
\hline $2011 / 75$ & May 7-20, 2011 & August 2011 \\
\hline $2010 / 74$ & November 11-25, 2010 & February 2011 \\
\hline $2010 / 73$ & May 7-22, 2010 & November 2010 \\
\hline $2009 / 72$ & October 30-November 13, 2009 & February and November 2010 \\
\hline $2009 / 71$ & June 13-26, 2009 & September 2009 \\
\hline $2008 / 70$ & October 6-22, 2008 & June 2010 \\
\hline $2008 / 69$ & March 25-May 4, 2008 & November 2008 (“Europeans' State of Mind") \\
\hline $2007 / 68$ & September 24-October 15, 2007 & May 2008 \\
\hline $2007 / 67$ & April 10-May 15, 2007 & November 2007 \\
\hline $2006 / 66$ & September 7-26, 2006 & September 2007 \\
\hline $2006 / 65$ & March 29-April 14, 2006 & January 2007 \\
\hline $2005 / 64$ & October 14-November 5, 2005 & June 2006 \\
\hline $2005 / 63$ & May 18-June 7, 2005 & September 2005 \\
\hline $2004 / 62$ & October 15-30, 2004 & May 2005 \\
\hline $2004 / 61$ & February 20-March 17, 2004 & July 2004 \\
\hline
\end{tabular}

${ }^{1}$ From "National Reports" in 2008 and before and "Factsheets" in 2009 and afterward.

${ }^{2}$ From "Public Opinion in the European Union," unless noted otherwise.

${ }^{3}$ Eurobarometer also published a separate report titled "Candidate Countries' Eurobarometer: 2004.1-Annex," with no date.

Source: Various Standard Eurobarometer surveys, http://ec.europa.eu/COMMFrontOffice/PublicOpinion/index.cfm/ Survey/index\#p=1\&instruments=STANDARD. 
Table 4

Polling Questions for Standard Eurobarometer and CVVM Surveys

\begin{tabular}{|c|c|c|c|}
\hline & Subject & Question Asked & Responses \\
\hline \multirow{3}{*}{ 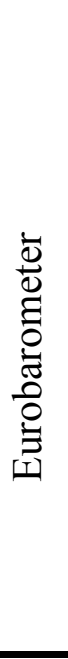 } & $\begin{array}{l}\text { Trust in the } \\
\text { EU }\end{array}$ & $\begin{array}{l}\text { I would like to ask you a question about how much trust } \\
\text { you have in certain institutions. For each of the following } \\
\text { institutions, please tell me if you tend to trust it or tend } \\
\text { not to trust it. The European Union. }\end{array}$ & $\begin{array}{l}\text { Tend to Trust } \\
\text { Tend Not to Trust } \\
\text { Do Not Know }\end{array}$ \\
\hline & $\begin{array}{l}\text { Image of the } \\
\text { EU }\end{array}$ & $\begin{array}{l}\text { In general, does the European Union conjure up for you a } \\
\text { very positive, fairly positive, neutral, fairly negative, or } \\
\text { very negative image? }\end{array}$ & \begin{tabular}{|l} 
Very Positive \\
Fairly Positive \\
Neutral \\
Fairly Negative \\
Very Negative \\
Do Not Know \\
\end{tabular} \\
\hline & $\begin{array}{l}\text { Direction of } \\
\text { the EU }\end{array}$ & $\begin{array}{l}\text { At the present time, would you say that, in general, things } \\
\text { are going in the right direction or in the wrong direction } \\
\text { in the European Union? }\end{array}$ & $\begin{array}{l}\text { Right Direction } \\
\text { Wrong Direction } \\
\text { Neither } \\
\text { Do Not Know }\end{array}$ \\
\hline \multirow{3}{*}{$\sum_{0}^{\sum}$} & $\begin{array}{l}\text { Evaluation of } \\
\text { Klaus as } \\
\text { President }\end{array}$ & $\begin{array}{l}\text { How would you evaluate up to now the activities of } \\
\text { Václav Klaus in the presidential office? How well does } \\
\text { he: Fulfill the function set out in the constitution? Ensure } \\
\text { the seriousness and dignity of the office? Represent the } \\
\text { Czech Republic abroad? Influence internal political life? } \\
\text { Stay in touch with citizens and knows their problems? } \\
\text { Appears to be an authority with the citizens? }\end{array}$ & $\begin{array}{l}\text { Very Well } \\
\text { Rather Well } \\
\text { Rather Poorly } \\
\text { Very Poorly }\end{array}$ \\
\hline & $\begin{array}{l}\text { Popularity of } \\
\text { Klaus }\end{array}$ & $\begin{array}{l}\text { Now I will read to you the names of several politicians. } \\
\text { For each one, please tell me whether you trust or do not } \\
\text { trust them or whether you cannot judge, in the case that } \\
\text { you do not know that politician. }\end{array}$ & $\begin{array}{l}\text { Trust } \\
\text { Do Not Trust } \\
\text { Do Not Know }\end{array}$ \\
\hline & $\begin{array}{l}\text { Confidence of } \\
\text { Klaus as } \\
\text { President }\end{array}$ & $\begin{array}{l}\text { Please say whether you trust the president of the republic, } \\
\text { the government of the Czech Republic, the Chamber of } \\
\text { Deputies of the Czech Republic, the Senate of the Czech } \\
\text { Republic, your provincial council, your municipal } \\
\text { council. }\end{array}$ & $\begin{array}{l}\text { Definitely Trust } \\
\text { Somewhat Trust } \\
\text { Somewhat Do Not Trust } \\
\text { Definitely Do Not Trust } \\
\text { Do Not Know }\end{array}$ \\
\hline
\end{tabular}

${ }^{1}$ The question beginning in 2013/80 substituted "media and institutions" for "institutions" in both halves of the question, to read: "I would like to ask you a question about how much trust you have in certain media and institutions. For each of the following media and institutions, please tell me if you tend to trust it or tend not to trust it. The European Union." ${ }^{2}$ The question for 2004/61 was: "And in general, do you have a very positive, fairly positive, neutral, fairly negative, or very negative image of the European Union?"

${ }^{3}$ After Klaus left office, canvassers posed the questions in the past tense.

Source: SE surveys, http://ec.europa.eu/COMMFrontOffice/publicopinion/index.cfm/Survey/index\#p=1\&instruments= STANDARD; and Centrum pro výzkum veřejného minění, Sociologický ústav AV ČR, v.v.i., "Důvěra k vybraným politikům" (occasionally appeared mistakenly as "Důvěra vybraným politikům”), "Důvěra k ústavním institucím," and "Hodnocení působení Václava Klause v prezidentském úřadě," all dates.

$-9-$

The Carl Beck Papers in Russian and East European Studies

http://carlbeckpapers.pitt.edu | DOI 10.5195/cbp.2017.219 | Number 2503 
Table 5

Data for Czech and European Union Citizens' Trust in the European Union (percent)

\begin{tabular}{|c|c|c|c|c|c|c|}
\hline \multirow[b]{2}{*}{ SE } & \multicolumn{3}{|c|}{ Czech Republic } & \multicolumn{3}{|c|}{ European Union Average } \\
\hline & $\begin{array}{c}\text { Tend to } \\
\text { Trust }\end{array}$ & $\begin{array}{c}\text { Tend Not } \\
\text { to Trust }\end{array}$ & $\begin{array}{l}\text { Do Not } \\
\text { Know }\end{array}$ & $\begin{array}{c}\text { Tend to } \\
\text { Trust }\end{array}$ & $\begin{array}{c}\text { Tend Not to } \\
\text { Trust }\end{array}$ & $\begin{array}{c}\text { Do Not } \\
\text { Know }\end{array}$ \\
\hline $2016 / 85$ & 28 & 62 & 10 & 33 & 55 & 12 \\
\hline $2015 / 84$ & 27 & 63 & 10 & 32 & 55 & 13 \\
\hline $2015 / 83$ & 43 & 45 & 12 & 40 & 46 & 15 \\
\hline $2014 / 82$ & 43 & 48 & 9 & 37 & 50 & 13 \\
\hline $2014 / 81$ & 32 & 61 & 7 & 31 & 56 & 13 \\
\hline $2013 / 80$ & 34 & 61 & 5 & 31 & 58 & 11 \\
\hline $2013 / 79$ & 35 & 60 & 5 & 31 & 60 & 9 \\
\hline $2012 / 78$ & 34 & 60 & 6 & 33 & 57 & 10 \\
\hline $2012 / 77$ & 30 & 63 & 7 & 31 & 60 & 9 \\
\hline $2011 / 76$ & 38 & 55 & 7 & 34 & 55 & 11 \\
\hline $2011 / 75$ & 45 & 48 & 7 & 41 & 47 & 12 \\
\hline $2010 / 74$ & 50 & 43 & 7 & 43 & 45 & 12 \\
\hline $2010 / 73$ & 50 & 45 & 5 & 42 & 47 & 11 \\
\hline $2009 / 72$ & 59 & 35 & 6 & 48 & 40 & 12 \\
\hline 2009/71 & 55 & 40 & 5 & 47 & 41 & 12 \\
\hline $2008 / 70$ & 58 & 33 & 9 & 47 & 41 & 12 \\
\hline $2008 / 69$ & 59 & 30 & 11 & 50 & 36 & 14 \\
\hline $2007 / 68$ & 58 & 33 & 9 & 48 & 36 & 16 \\
\hline $2007 / 67$ & 61 & 32 & 7 & 57 & 32 & 11 \\
\hline $2006 / 66$ & 62 & 30 & 9 & 45 & 40 & 14 \\
\hline $2006 / 65$ & 60 & 29 & 10 & 48 & 39 & 13 \\
\hline $2005 / 64$ & 53 & 38 & 9 & 45 & 43 & 12 \\
\hline $2005 / 63$ & 52 & 38 & 10 & 44 & 43 & 13 \\
\hline $2004 / 62$ & 52 & 32 & 16 & 50 & 36 & 14 \\
\hline $2004 / 61$ & 42 & 31 & 27 & 41 & 42 & 17 \\
\hline
\end{tabular}

Source: Standard Eurobarometer surveys, http://ec.europa.eu/COMMFrontOffice/publicopinion/index.cfm/Survey/ index $\# p=1 \&$ instruments $=$ STANDARD. Because of rounding, the totals may be slightly more or less than 100 percent. 
Figure 1

Czech and European Union Citizens' Trust in the European Union, from 2004 to the First Half of 2013

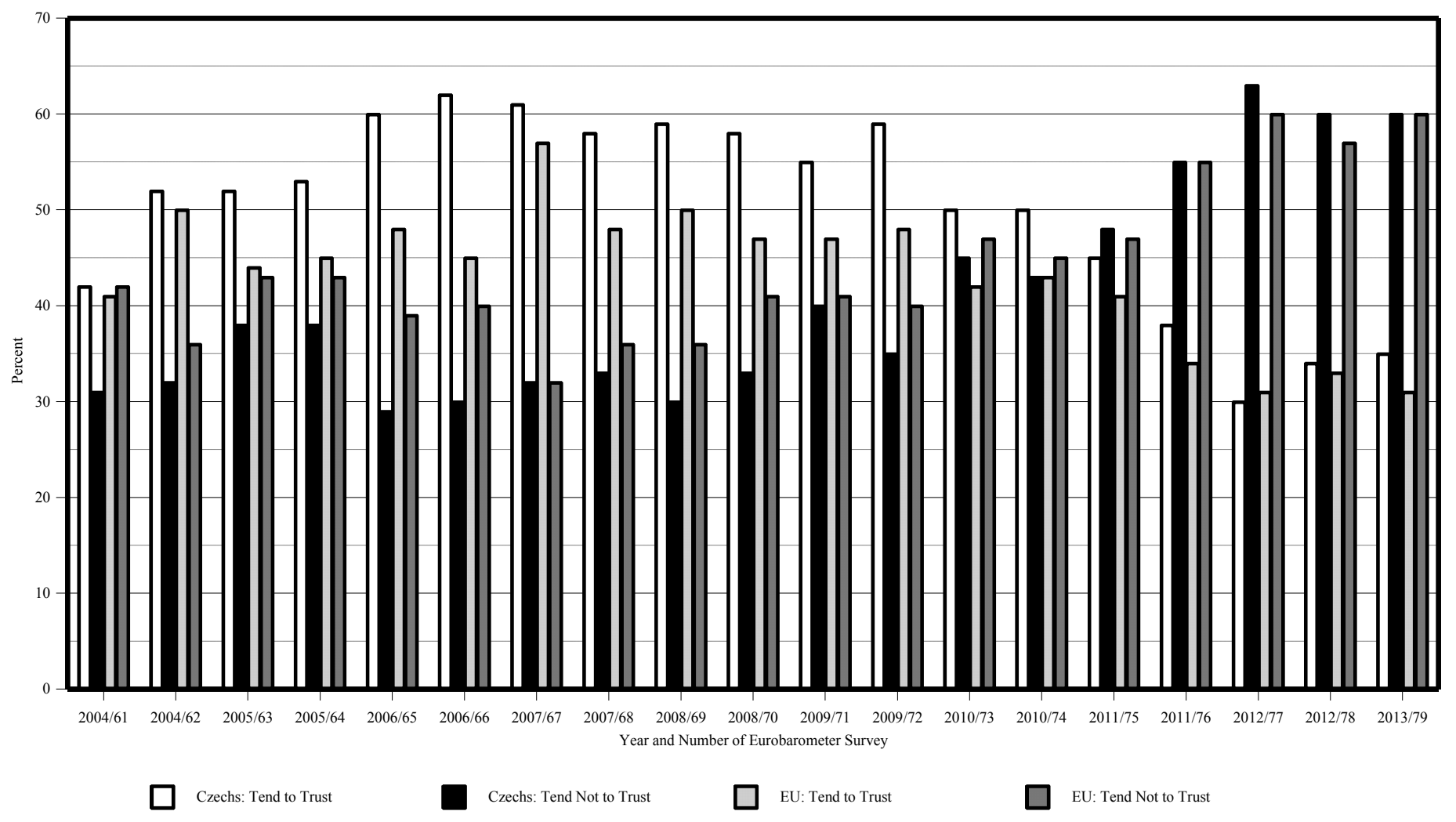

Source: Standard Eurobarometer surveys, http://ec.europa.eu/COMMFrontOffice/PublicOpinion/index.cfm/Survey/ index\#p=1\&instruments $=$ STANDARD. 
Table 6

Data for Czech and European Union Citizens' Image of the European Union (percent)

\begin{tabular}{|c|c|c|c|c|c|c|c|c|c|}
\hline SE & Location & $\begin{array}{c}\text { Very } \\
\text { Positive }\end{array}$ & $\begin{array}{c}\text { Fairly } \\
\text { Positive }\end{array}$ & Neutral & $\begin{array}{c}\text { Fairly } \\
\text { Negative }\end{array}$ & $\begin{array}{c}\text { Very } \\
\text { Negative }\end{array}$ & $\begin{array}{c}\text { Do Not } \\
\text { Know }\end{array}$ & $\begin{array}{c}\text { Total } \\
\text { Positive }\end{array}$ & $\begin{array}{c}\text { Total } \\
\text { Negative }\end{array}$ \\
\hline \multirow{2}{*}{85} & ..ČR. & 1. & 25. & .40. & 25. & 9. & 0 . & 26. & .34. \\
\hline & EU" & 4 & 30 & 38 & 20 & 7 & 1 & 34 & 27 \\
\hline \multirow{2}{*}{84} & ..Čn. & 2. & 25. & 42. & 22. & 9. & . & 27. & 31. \\
\hline & EU & $\because 3$ & 33 & 38 & 18 & 3 & $\ddot{2}$ & 37 & 23 \\
\hline \multirow{2}{*}{83} & ..ČR. & 5. & 32. & 42. & 17. & 3 & 1. & 37 & 20 \\
\hline & $\mathrm{EU}$ & 5 & 36 & 38 & 15 & 4 & 2 & 41 & 19 \\
\hline \multirow{2}{*}{82} & C.C.R. & 2. & 35 & 40. & 17 & 5 & 1. & 37 & 22. \\
\hline & $\mathrm{EU}$ & 4 & 35 & 37 & 17 & 5 & 2 & 39 & 22 \\
\hline \multirow{2}{*}{81} & ČR. & 3. & 26 & 43 & 19 & 9 & 0 & 29 & 28 \\
\hline & $\mathrm{EU}$ & 4 & 31 & 38 & 19 & $\ddot{6}$ & $\ddot{2}$ & 35 & 25 \\
\hline \multirow{2}{*}{80} & ..Čn. & 1. & 23. & .42. & 25. & 8 & 1. & 24 & 33 \\
\hline & $\mathrm{EU}$ & 3 & 28 & 39 & 21 & 7 & 2 & 31 & 28 \\
\hline \multirow{2}{*}{79} & ČR. & 3. & 22 & 39 & 27 & 9 & 0 & 25 & 36 \\
\hline & EU & 3 & 27 & 39 & 22 & 7 & 2 & 30 & 29 \\
\hline \multirow{2}{*}{78} & ČR & 2. & 19 & 43. & 25 & 10 & 1. & 21 & 35 \\
\hline & EU & 3 & 27 & 39 & 22 & 7 & 23 & 30 & 29 \\
\hline \multirow{2}{*}{77} & ČR & 2. & 20 & 43. & 25. & 9. & 1. & 22 & 34 \\
\hline & EU & 3 & 28 & 39 & 22 & 6 & 2 & 31 & 28 \\
\hline \multirow{2}{*}{76} & ČR & 3 & 23 & 42. & 24 & 8 & 0 & 26 & 32 \\
\hline & EU & 3 & 28 & 41 & 20 & $\ddot{6}$ & $\ddot{2}$ & 31 & 26 \\
\hline \multirow{2}{*}{75} & C.C.R. & 3 & 26 & 43. & 20. & .. & 1. & 29 & 27. \\
\hline & EU & 3 & 35 & 38 & 16 & $\ddot{4}$ & $\ddot{2}$ & 40 & 20 \\
\hline \multirow{2}{*}{74} & .. ČR & 4. & 28 & 45 & 18 & 5 & 0 & 32 & 23 \\
\hline & EU & 4 & 34 & 40 & 16 & 3 & 2 & 38 & 20 \\
\hline \multirow{2}{*}{73} & ČR & 3 & 32 & 39 & 18 & 7 & 1 & 35 & 25 \\
\hline & $\mathrm{EU}$ & 6 & 36 & 37 & 15 & 4 & 2 & 42 & 19 \\
\hline \multirow{2}{*}{72} & ČR & 5 & 36 & 39 & 15 & 5 & 0 & 41 & 20 \\
\hline & EU & 7 & 41 & 35 & 12 & 3 & $\ddot{2}$ & 48 & 15 \\
\hline \multirow{2}{*}{71} & .. ČR & 6. & 33. & 40. & 15 & 6 & 0 & 39 & 21. \\
\hline & EU & 6 & 39 & 36 & 12 & $\ddot{4}$ & 3 & 45 & 16 \\
\hline \multirow{2}{*}{70} & ČR & 6 & 38 & 37 & 15 & 4 & 0 & 44 & 19 \\
\hline & $\mathrm{EU}$ & 6 & 39 & 36 & 13 & $\ddot{4}$ & 2 & 45 & 17 \\
\hline \multirow{2}{*}{69} & ČR & 6. & 37. & 40. & 13. & 3. & 1. & 47 & 16 \\
\hline & $\mathrm{EU}$ & 7 & 41 & 35 & 12 & 3 & 2 & 48 & 15 \\
\hline \multirow{2}{*}{68} & ČR & 6 & 37 & 40 & 13 & 3 & 1. & 47 & 16 \\
\hline & EU & 7 & 41 & 35 & 12 & 3 & $\ddot{2}$ & 48 & 15 \\
\hline \multirow{2}{*}{67} & ČR & 6 & 39 & 34 & 17 & 4 & 0 & 45 & 21 \\
\hline & EU & 11 & 41 & 31 & 12 & 3 & $\ddot{2}$ & 32 & 15 \\
\hline 66 & Č́R & .9. & 39 & 34 & 14. & 3. & 0. & .48 & 18 \\
\hline 60 & EU & 7 & 39 & 34 & 14 & 4 & $\ddot{3}$ & 46 & 17 \\
\hline 65 & ČR & 9 & 41 & 33 & 13 & 4 & 1 & 50 & 16 \\
\hline 65 & EÜ & ".." & 41 & 32 & 12 & $\ddot{4}$ & 2 & 50 & 13 \\
\hline 64 & ČnR & 6 & 34 & 40. & 16 & 4 & 1. & 40 & 20 \\
\hline 64 & EU & 7 & 37 & 34 & 13 & 3 & "ï & 34 & 20 \\
\hline 62 & ČR & 5 & 38 & 36 & 17 & 4 & 1 & 43 & 21 \\
\hline 03 & EU & 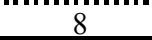 & 38 & 32 & 14 & 4 & 2 & 47 & 19 \\
\hline 62 & ........ & 4. & .35 & 38 & 17 & 3. & 2 & .40 & 20 \\
\hline 62 & EU & 10 & 40 & 33 & 12 & 3 & 2 & 50 & 15 \\
\hline 61 & ČR & 6 & 21 & 29 & 34 & 5 & 5 & 27 & 39 \\
\hline 01 & EU & 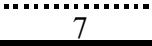 & 36 & 32 & 13 & 6 & 4 & 43 & 21 \\
\hline
\end{tabular}

Source: SE surveys, http://ec.europa.eu/COMMFrontOffice/publicopinion/index.cfm/Survey/index\#p=1\&instruments=STANDARD. Because of rounding, the totals may be slightly more or less than 100 percent. In the table, ČR stands for Česká republika or Czech Republic. 
Figure 2

\section{Czech and European Union Citizens with a Negative Image of the European Union}

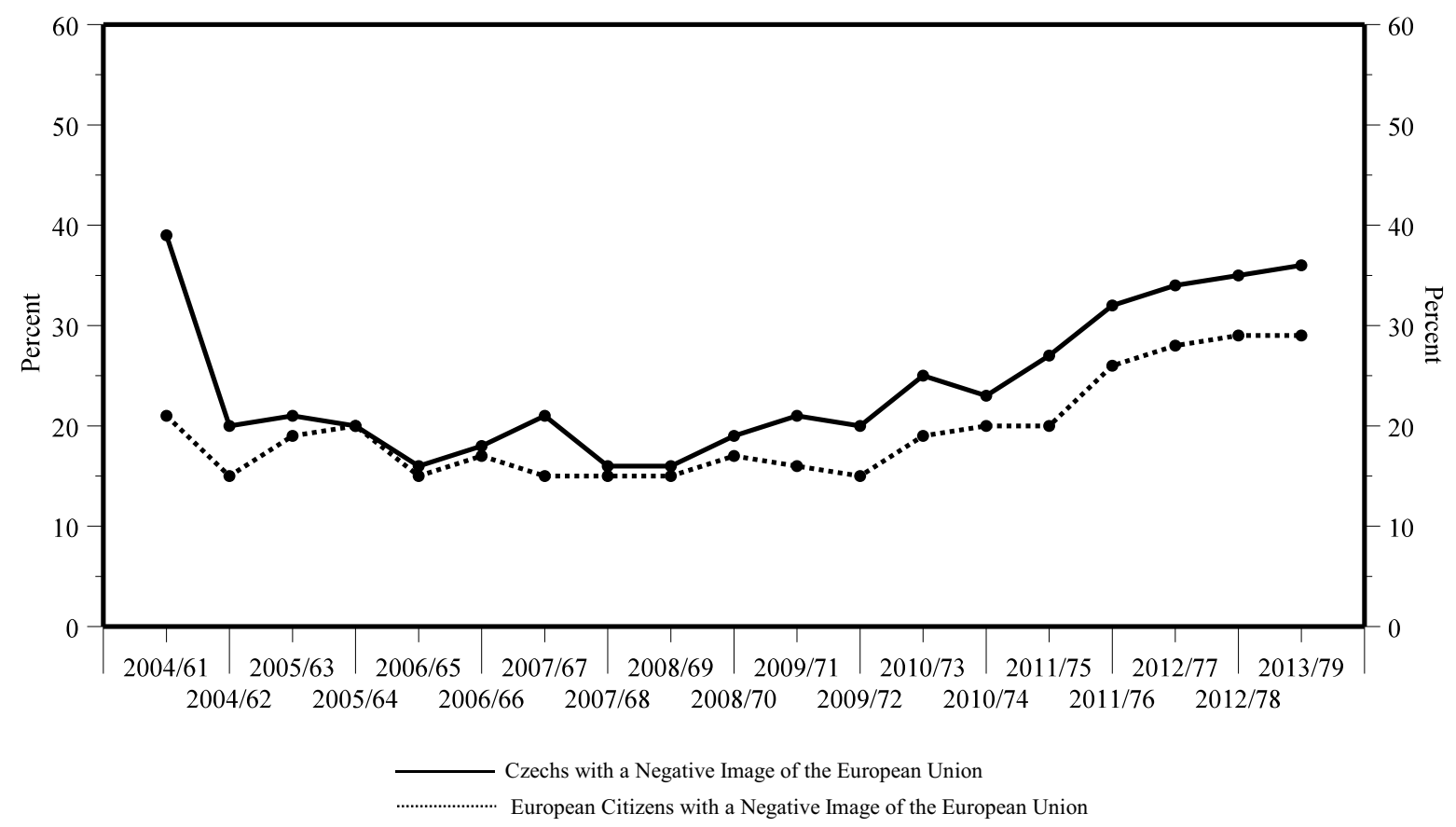

Source: Standard Eurobarometer surveys, http://ec.europa.eu/COMMFrontOffice/publicopinion/index.cfm/ Survey/index\#p=1\&instruments=STANDARD.

$-13-$

The Carl Beck Papers in Russian and East European Studies

http://carlbeckpapers.pitt.edu | DOI 10.5195/cbp.2017.219 | Number 2503 


\section{Table 7 \\ Data for Czech and European Union Citizens' Opinion about the Direction of the EU} (percent)

\begin{tabular}{|c|c|c|c|c|c|}
\hline SE & Location & Right Direction & Wrong Direction & Neither & Do Not Know \\
\hline \multirow{2}{*}{$2016 / 85$} & ČR & 47 & 37 & 6 & 10 \\
\hline & EU" & 45 & 31 & 14 & 10 \\
\hline \multirow{2}{*}{$2015 / 84$} & ČR & 20 & 52 & 22 & 6 \\
\hline & EÜ & 23 & 43 & 23 & 11 \\
\hline \multirow{2}{*}{$2015 / 83$} & ČR & 34 & 28 & 30 & 8 \\
\hline & EÜ & 28 & 35 & 24 & 13 \\
\hline \multirow{2}{*}{$2014 / 82$} & ČR & 35 & 30 & 24 & 11 \\
\hline & EU & 25 & 39 & 24 & 12 \\
\hline \multirow{2}{*}{$2014 / 81$} & ČR & 29 & 36 & 26 & 9 \\
\hline & EÜ & 25 & 38 & 23 & 14 \\
\hline \multirow{2}{*}{$2013 / 80$} & ČR & 30 & 47 & 18 & 5 \\
\hline & EÜ & 26 & 47 & 18 & 9 \\
\hline \multirow{2}{*}{ 2013/79 } & ČR & 27 & 49 & 19 & 5 \\
\hline & EÜ & 23 & 49 & 19 & 9 \\
\hline \multirow{2}{*}{$2012 / 78$} & ČR & 22 & 53 & 20 & 5 \\
\hline & EU & 22 & 52 & 18 & 8 \\
\hline \multirow{2}{*}{$2012 / 77$} & ČR & 22 & 54 & 18 & 6 \\
\hline & EU & 21 & 53 & 17 & 9 \\
\hline \multirow{2}{*}{$2011 / 76$} & ČR & 23 & 56 & 16 & 5 \\
\hline & $\mathrm{EU}$ & 19 & 55 & 17 & 9 \\
\hline \multirow{2}{*}{$2011 / 75$} & ČR & 38 & 38 & 17 & 7 \\
\hline & EÜ & 31 & 40 & 19 & 10 \\
\hline \multirow{2}{*}{$2010 / 74$} & $\check{C} \mathrm{C}$ & 42 & 34 & 18 & 6 \\
\hline & $\mathrm{EU}$ & 30 & 29 & 20 & 11 \\
\hline \multirow{2}{*}{$2010 / 73$} & ČR & 40 & 37 & 19 & 4 \\
\hline & $\mathrm{EU}$ & 32 & 37 & 19 & 12 \\
\hline \multirow{2}{*}{ 2009/72 } & $\check{C \check{R}}$ & 47 & 28 & 21 & 4 \\
\hline & EÜ & 40 & 28 & 20 & 12 \\
\hline \multirow{2}{*}{$2009 / 71$} & ČRR. & 45 & 29 & 20 & 6. \\
\hline & $\mathrm{EU}$ & 34 & 35 & 20 & 11 \\
\hline \multirow{2}{*}{$2008 / 70$} & ČR & 47 & 24 & 23 & 6 \\
\hline & EÜ & 35 & 34 & 19 & 12 \\
\hline \multirow{2}{*}{$2008 / 69$} & ČR & 50 & 16 & 26 & 8 \\
\hline & EU & 42 & 25 & 19 & 14 \\
\hline \multirow{2}{*}{$2007 / 68$} & ČnR. & 44 & 21 & 26 & 9 \\
\hline & EU & 40 & 23 & 21 & 16 \\
\hline \multirow{2}{*}{$2007 / 67$} & ČR & 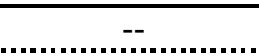 &.-- & $\ldots$ &.-- \\
\hline & EÜ & --." & $-\cdot$ & --" & $\cdots \cdot-$ \\
\hline \multirow{2}{*}{$2006 / 66$} & ČR & 52 & 18 & 23 & 7 \\
\hline & EÜ & 33 & 33 & 20 & 14 \\
\hline
\end{tabular}

Source: SE surveys, http://ec.europa.eu/COMMFrontOffice/publicopinion/index.cfm/Survey/index\#p=1\&instruments= STANDARD. Because of rounding, the totals may be slightly more or less than 100 percent. The question asking citizens' opinions about the direction of the EU did not appear in 2007/67. In the table, ČR stands for Česká republika or Czech Republic. 
Figure 3

Czech and European Union Citizens with Negative Opinions about the Direction of the EU

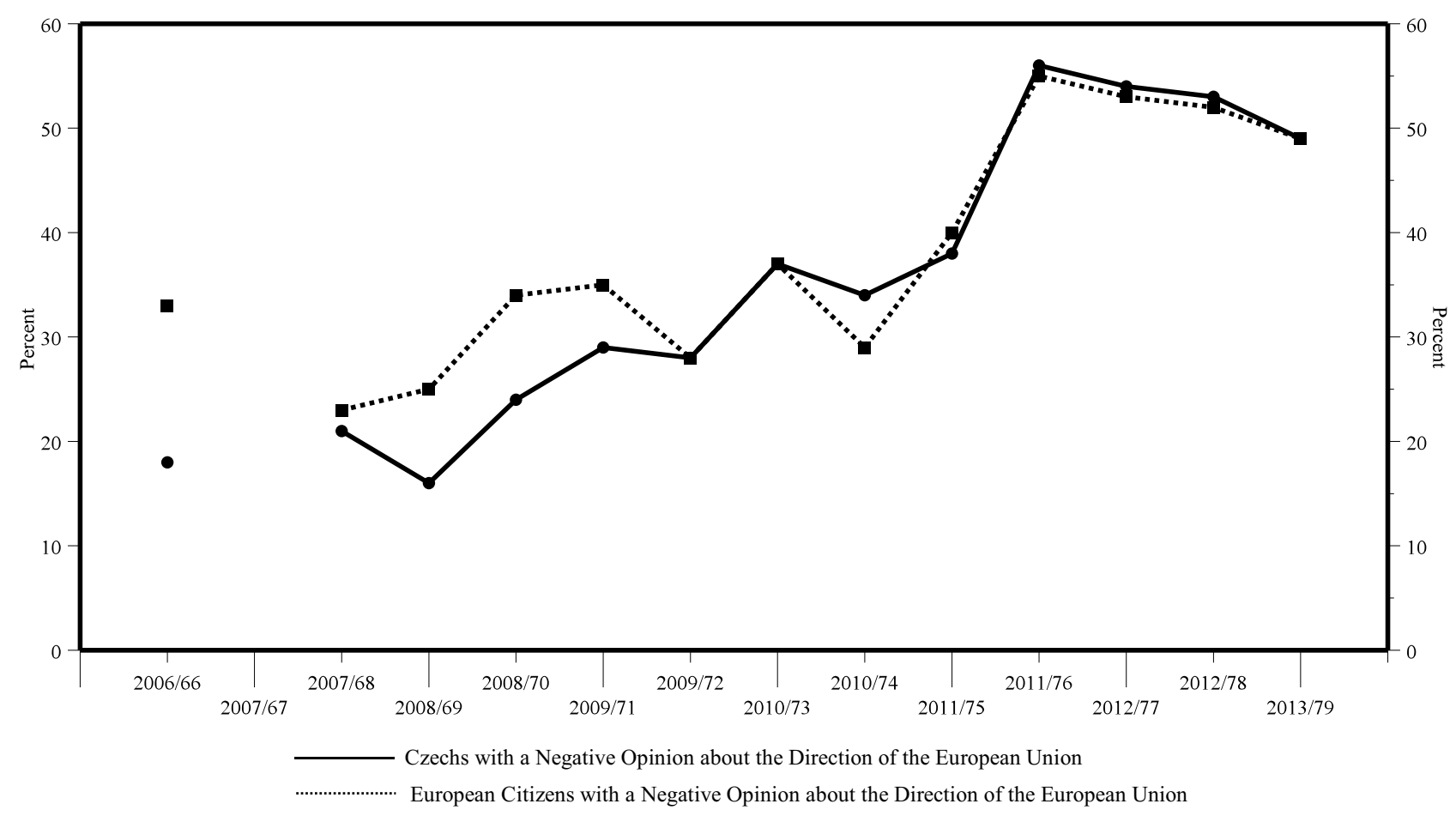

Source: Standard Eurobarometer surveys, http://ec.europa.eu/COMMFrontOffice/publicopinion/index.cfm/Survey/ index\#p=1\&instruments=STANDARD. In 2006/66, the EU was at 33 percent; the Czech Republic, at 18 percent. 
Table 8

Euroskepticism Index for the Czech Republic

\begin{tabular}{|c|c|c|c|c|}
\hline \multirow[b]{2}{*}{$\begin{array}{c}\text { Standard } \\
\text { Eurobarometer }\end{array}$} & \multicolumn{3}{|c|}{ Percent } & \multirow[b]{2}{*}{ Euroskepticism Index } \\
\hline & $\begin{array}{c}\text { Distrust in the } \\
\text { EU }\end{array}$ & $\begin{array}{c}\text { Negative Image } \\
\text { of the EU }\end{array}$ & $\begin{array}{c}\text { EU is Headed } \\
\text { in the Wrong } \\
\text { Direction }\end{array}$ & \\
\hline $2016 / 85$ & 62 & 34 & 37 & 44.3 \\
\hline $2015 / 84$ & 63 & 31 & 52 & 48.7 \\
\hline $2015 / 83$ & 45 & 20 & 28 & 31.0 \\
\hline $2014 / 82$ & 48 & 22 & 30 & 33.3 \\
\hline $2014 / 81$ & 61 & 28 & 36 & 41.7 \\
\hline $2013 / 80$ & 61 & 33 & 47 & 47.0 \\
\hline $2013 / 79$ & 60 & 36 & 49 & 48.3 \\
\hline $2012 / 78$ & 60 & 35 & 53 & 49.3 \\
\hline $2012 / 77$ & 63 & 34 & 54 & 50.0 \\
\hline $2011 / 76$ & 55 & 32 & 56 & 47.7 \\
\hline $2011 / 75$ & 48 & 27 & 38 & 37.7 \\
\hline $2010 / 74$ & 43 & 23 & 34 & 33.3 \\
\hline $2010 / 73$ & 45 & 25 & 37 & 35.7 \\
\hline 2009/72 & 35 & 20 & 28 & 27.7 \\
\hline $2009 / 71$ & 40 & 21 & 29 & 30.0 \\
\hline $2008 / 70$ & 33 & 19 & 24 & 25.3 \\
\hline $2008 / 69$ & 30 & 16 & 16 & 20.7 \\
\hline $2007 / 68$ & 33 & 16 & 21 & 23.3 \\
\hline $2007 / 67$ & 32 & 21 & -- & 26.5 \\
\hline $2006 / 66$ & 30 & 18 & 18 & 22.0 \\
\hline $2006 / 65$ & 29 & 16 & -- & 22.5 \\
\hline $2005 / 64$ & 38 & 20 & $\overline{--}$ & 29.0 \\
\hline $2005 / 63$ & 38 & 21 & $\overline{--}$ & 29.5 \\
\hline $2004 / 62$ & 32 & 20 & -- & 26.0 \\
\hline $2004 / 61$ & 31 & 39 & $\begin{array}{ll}- \\
--\end{array}$ & 35.0 \\
\hline
\end{tabular}

Source: Tables 5, 6, and 7. The Euroskepticism Index is the average of distrust in the EU, negative image of the EU, and the opinion that the EU is headed in the wrong direction. The Standard Eurobarometers for 2004/61 to 2006/65 as well as $2007 / 67$ did not measure the opinion about the direction of the EU. The Euroskepticism Index mean average is 32.61 percent for the time Klaus was in office, that is, between ES surveys 2004/61 and 2013/79. 


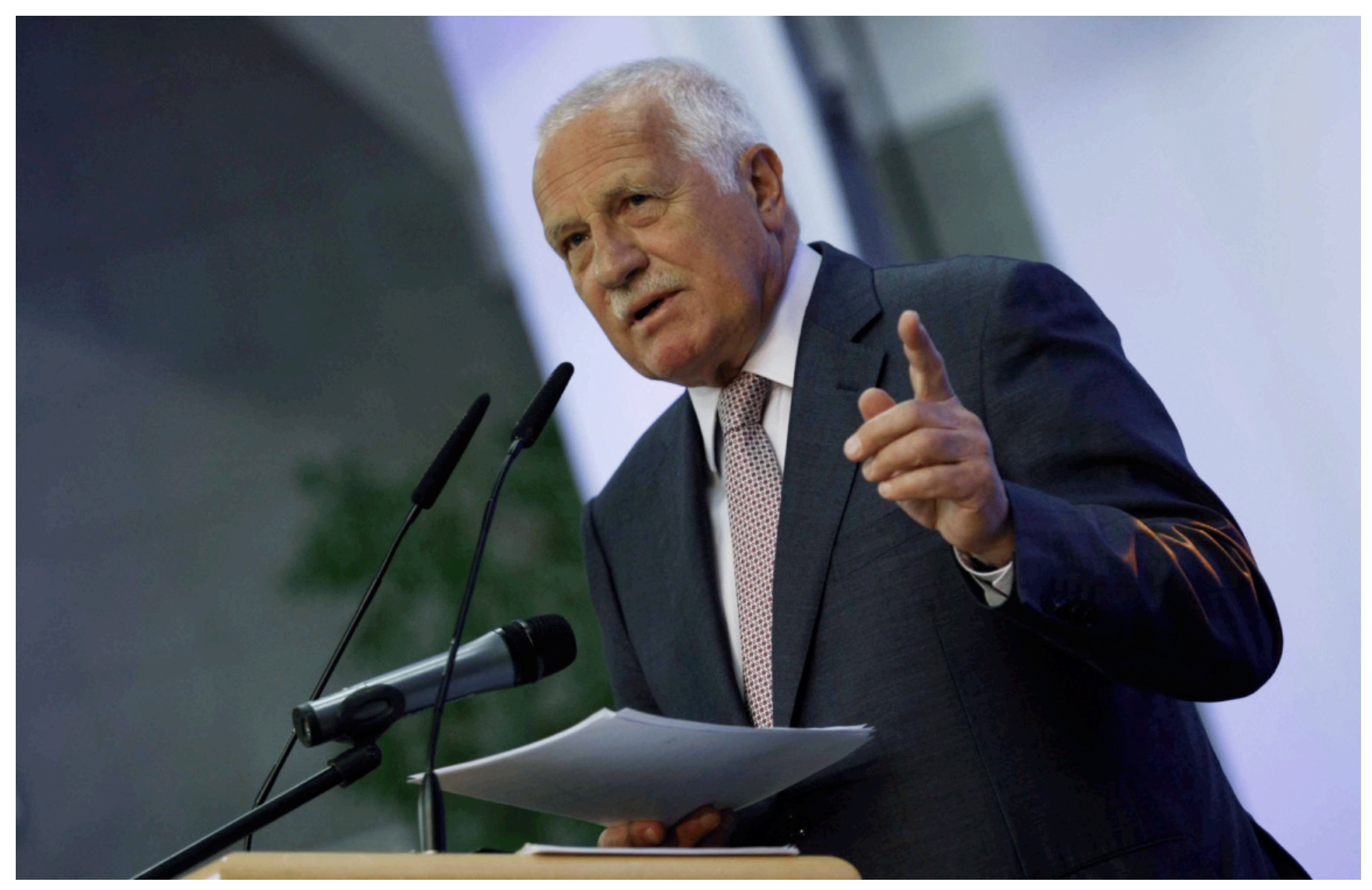

Former President Václav Klaus presenting a lecture at the University of Economics in Prague (Vysoká škola ekonomická v Praze) on 18 May 2014. Photo: Petr Horník, Právo. 
Positive and negative opinions about the EU were inversely related. In the first five surveys, to the spring of 2006, there was an overall incline in the numbers of Czech citizens who viewed the EU favorably. After the positive image reached its apogee of 50 percent, in the spring of 2006, it faced a continuous decline, apart from small recoveries in autumn 2009, spring 2012, and spring 2013. More Europeans held a positive image of the EU than the Czechs, even if the percentage was at times slight, except for spring 2006, when both were 50 percent, and autumn 2006, when Czechs with a positive image of the EU were at 48 percent. At that time, the European average was two percentage points lower, which was negligible.

The SE question about whether the EU is headed in the right direction premiered in the autumn of 2006 (see Table 7 and Figure 3). It did not appear in the spring of 2007, but between autumn 2006 and spring 2013, it was on every survey. In autumn 2006, 18 percent of the Czechs believed that the EU was headed in the wrong direction. That percentage increased slightly in autumn 2007, fell in spring 2008, and rose steadily over the years, with a slight dip in autumn 2010. Then, in autumn 2011, it reached a height of 56 percent.

Afterward, it dropped to some degree. For the most part, the overall Czech perception that the EU was headed in the wrong direction reflected the mood throughout the EU. Europeans were negative about the direction of the EU in spring 2006, but pessimism decreased by autumn 2007, and it paralleled the negative perception among Czechs, although at a higher percentage. Beginning in autumn 2009, when both the European and Czech averages stood at 28 percent, the Czech and general European negative assessment of the direction of the EU were nearly identical, aside from a somewhat larger spread in autumn 2010. The peak for both occurred in autumn 2011, and the percentages declined afterward.

The three categories of trust or distrust in the EU, the positive or negative image of the EU, and the opinion about the direction in which the EU is proceeding have remarkable parallels and together form a reasonable indicator of Euroskepticism. Therefore, this study used them to create the Euroskepticism Index (EI), which is the average of all three percentages-an average of two percentages if the SE did not include the question about the EU's direction (see Table 8). The index demonstrates that the optimism present when the Czech Republic entered the EU, in spring 2004, started to dissipate in the course of the next four years, despite resurgences in spring 2005 and spring 2007. After reaching its nadir in the spring of 2008, optimism increased, dipping only in the autumn of 2009 and 2010. The EI peaked in the spring of 2012, a year before Klaus finished his second term in office, then it decreased slightly in the following year.

\section{Correlating the Euroskepticism of Czechs and Confidence in President Klaus}

Remarkably, the Czech population's confidence in the presidency, as seen in the CVVM surveys while Klaus was in office, at times closely paralleled the SE-based Euroskepticism Index (see Figure 4). For the first two and one half years that the Czech Republic was in the EU, there was little correspondence between trust in the presidency and Euroskepticism. In the first year, Czechs' distrust of the EU fluctuated little, while their image of the EU fell considerably. Throughout the year, trust in the presidency hovered in the middle 70s. In the spring of 2005, distrust in the EU rose, the negative image of the EU was steady, and trust in the presidency declined. These percentages were about the same in autumn 2005. In the spring of 2006, both Euroskepticism indicators decreased, and confidence in Klaus increased somewhat. From that point, there was a more positive correlation between trust in the presidency and Euroskepticism. As trust in the presidency strengthened somewhat in the autumn of 2006 and varied little in the spring of 2007, both Euroskepticism indicators ticked upward. Trust in the presidency deteriorated in the autumn of 2007, as did the negative image of the EU. Distrust in the EU grew only slightly. Then, trust in the presidency diminished again in the spring of 2008, as did distrust in the EU. The opinion that the EU was headed in the wrong direction also dropped. This was the first time that there is enough data on this question to observe a trend. ${ }^{32}$ The negative image of the EU remained the same. When trust in the presidency increased in the autumn of 2008 and the spring of 2009, so did all three indicators of Euroskepticism. Trust in the presidency decreased in the autumn of 2009, then it improved again in the spring of 2010; all three Euroskepticism indicators did the same. In the second half of 2010, divergence 
began to appear. Trust in the presidency gained a bit in the autumn of 2010, while all three levels of Euroskepticism declined. In the spring of 2011, trust in the presidency began a marked descent and never recovered while Klaus was in office. Throughout 2011, all three Euroskepticism indicators increased. In the spring of 2012, distrust of the EU and the negative image of the EU continued to rise, but the notion that the EU was headed in the wrong direction fell, as did trust in the presidency. In the autumn of 2012, the number of those who distrusted the EU and felt it was going in the wrong direction declined, keeping pace with the loss of confidence the Czechs had in the presidency, while the number of those who expressed a negative image of the EU continued its slow climb. In the spring of 2013, when Klaus was about to leave office, trust in the presidency reached its lowest point. The number of those who believed that the EU was headed in the wrong direction decreased, but at a more gradual rate than for those who trusted the presidency. The number of those who distrusted the EU and had a negative image of the EU rose slightly.

Figure 5 illustrates the Czechs' confidence in Klaus as well as the EI, as seen in Table 8, for the period of 2004 through the first half of 2013, the entire length of Klaus's presidency. The correlation coefficient for the two is -0.68 , indicating a divergent overall relationship between the variables. ${ }^{33}$ Nevertheless, there is one lengthy stretch when the relationship was positive, with a correlation of 0.23 : the seven-year period from 2004 until the end of 2010. ${ }^{34}$ The change in direction of the correlation, from negative to positive, suggests that Klaus succeeded in pushing the public in the opposite direction, that is, toward a heightened degree of Euroskepticism.

Within the time frame of 2004 to 2010 , there were two key moments. The first was the spring and autumn of 2005, when the correlation was 1.0, but two points are insufficient to provide a p-value, so the comparison for that year is of limited use. The second is from spring 2007 through 2010, when the correlation is 0.47 , although the r-squared is only 0.2228 , and the $p$-value is 0.237658 , so the result is not significant at $p<$ 0.05 . The sample size, however, is very small-only eight pairs-resulting in some uncertainty about the correlation; however, the correlations over shorter increments of time tend to be close to statistical significance at the 5 percent level. Although the p-value for the spring 2007 through 2010 period implies that one cannot exclude the possibility that confidence in Klaus has no relationship to the Euroskepticism Index (the null hypothesis), the correlation suggests that one also cannot rule out a connection between the two and that the Czechs' confidence in Klaus at least contributed, in some way, to the level of their Euroskepticism.

Furthermore, every six months, between the beginning of 2007 and the end of 2010, the correlation between confidence in Klaus and the EI increased, aside from the time between the spring and autumn of 2008 and the spring and autumn of 2010. The correlations for 2007/2 through 2010/2, 2008/2 through 2010/2, and 2009/1 through 2010/2 are close to being statistically significant at 5 percent, and they are statistically significant at 10 percent. Despite some degree of uncertainty, the data suggests that Klaus pushed the Czech public in a Euroskeptic direction..$^{35}$

\section{Klaus's Criticisms of the EU and Czech Euroskepticism: More than Coincidence}

The abundance of Klaus's writings, speeches, and interviews critical of the EU provides ample evidence to identify the components of his brand of Euroskepticism. It is impossible to consider all of this material here, but certain statements of Klaus concisely express his standpoint and help account for the publicity he attained at home and abroad. Furthermore, the frequency of his anti-EU messages further enhanced the likelihood that he successfully propagated his views. A casual glance at the ten volumes of collected speeches, essays, and other statements he published during his decade in office, although each volume often excludes a number of items, reveals that Klaus wrote or spoke about the EU, including the eurozone and euro, at least 12 times a year, on the average.$^{36}$ Klaus delivered a simple message of Euroskepticism, containing several key points, in a variety of venues, and he did so with a steady frequency that convinced many of his fellow citizens to accept or at least consider his viewpoints. Furthermore, Klaus published a number of other books during his presidency, all of which contained segments that 


\section{Figure 4 \\ Composite View of Confidence in Klaus along with the Czech Citizens' Trust, Image, and opinion of the Direction of the EU}

Source: SE surveys, available at http://ec.europa.eu/COMMFrontOffice/PublicOpinion/index.cfm/Survey/index\#p= 1\&instruments=STANDARD, and CVVM, "Důvěra vybraným politikům,” 23 June 2004, 29 May 2007, 7 January 2008,

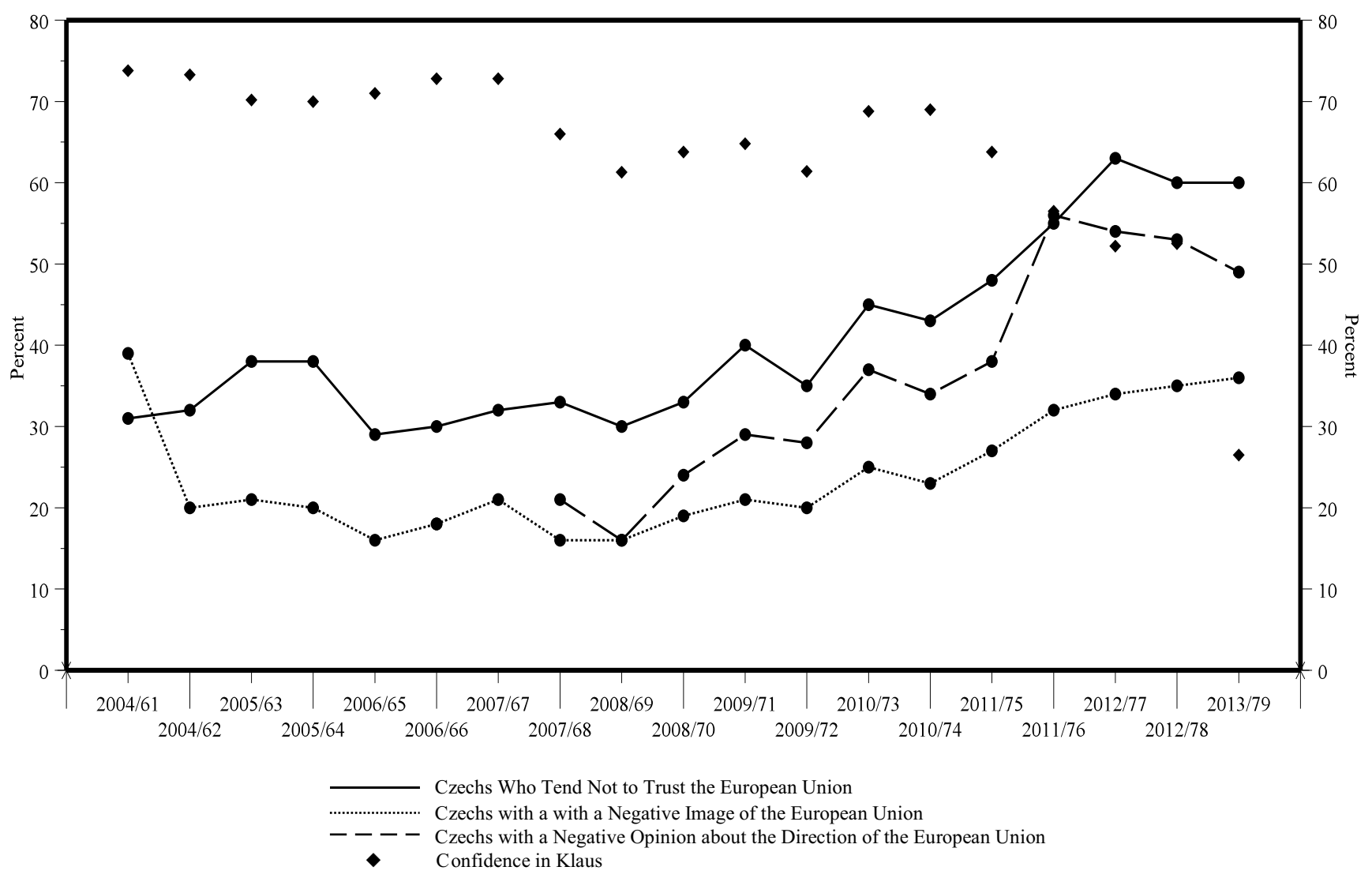

30 March 2011, and 1 October 2013, table 1 in each case, http://cvvm.soc.cas.cz/. The autumn of 2006 was the first time SE asked about the direction of the EU. The percentage was the same as those who had a negative opinion of the EU and is not apparent on the diagram. In the spring of 2007, SE did not ask about the direction of the EU. Confidence in Klaus here is from the averages in Table 2. 
Table 9

Czech Economic Sentiment Indicators, 2004-2013, Adjusted Seasonally ${ }^{1}$

\begin{tabular}{|l|c|c|c|c|c|c|c|c|c|c|c|}
\hline Month & $\mathbf{2 0 0 3}$ & $\mathbf{2 0 0 4}$ & $\mathbf{2 0 0 5}$ & $\mathbf{2 0 0 6}$ & $\mathbf{2 0 0 7}$ & $\mathbf{2 0 0 8}$ & $\mathbf{2 0 0 9}$ & $\mathbf{2 0 1 0}$ & $\mathbf{2 0 1 1}$ & $\mathbf{2 0 1 2}$ & $\mathbf{2 0 1 3}$ \\
\hline January & 106.0 & 105.5 & 109.0 & 112.3 & 116.5 & 111.8 & 78.7 & 89.8 & 102.5 & 90.9 & 88.0 \\
\hline February & 104.9 & 102.4 & 108.8 & 113.1 & 118.4 & 114.9 & 73.0 & 91.9 & 99.9 & 92.5 & 87.9 \\
\hline March & 106.0 & 102.0 & 108.2 & 113.5 & 117.3 & 113.7 & 75.4 & 91.9 & 98.5 & 92.8 & 88.2 \\
\hline April & 107.2 & 105.6 & 105.5 & 111.3 & 115.9 & 113.7 & 81.2 & 96.5 & 97.1 & 90.6 & 85.4 \\
\hline May & 104.5 & 106.6 & 109.5 & 112.8 & 115.1 & 108.7 & 81.4 & 96.6 & 96.1 & 88.8 & 87.3 \\
\hline June & 105.6 & 109.7 & 107.3 & 113.7 & 114.2 & 106.5 & 81.1 & 97.1 & 96.9 & 88.4 & 88.5 \\
\hline July & 102.7 & 109.5 & 109.7 & 114.4 & 113.9 & 106.2 & 83.1 & 100.3 & 96.6 & 86.2 & 87.2 \\
\hline August & 106.0 & 110.3 & 108.7 & 116.1 & 114.3 & 104.5 & 80.5 & 98.8 & 95.9 & 87.2 & 89.6 \\
\hline September & 102.8 & 109.0 & 111.1 & 114.2 & 115.2 & 101.9 & 82.7 & 98.6 & 92.0 & 87.3 & 92.3 \\
\hline October & 104.9 & 108.8 & 110.8 & 115.7 & 114.7 & 96.2 & 81.7 & 97.7 & 95.8 & 86.5 & 94.7 \\
\hline November & 11.5 & 108.7 & 110.1 & 114.5 & 112.6 & 91.8 & 85.9 & 99.0 & 90.5 & 85.4 & 97.0 \\
\hline December & 105.3 & 111.0 & 111.7 & 115.6 & 109.6 & 82.8 & 88.9 & 103.4 & 88.5 & 87.7 & 97.3 \\
\hline First Half ${ }^{2}$ & 105.7 & 105.3 & 108.1 & 112.8 & 116.2 & 111.6 & 78.5 & 94.0 & 98.5 & 90.7 & 87.6 \\
\hline Second Half ${ }^{3}$ & 105.5 & 109.6 & 110.4 & 115.1 & 113.4 & 97.2 & 83.8 & 99.6 & 93.2 & 86.7 & 93.0 \\
\hline
\end{tabular}

${ }^{1}$ The Economic Sentiment Indicator (ESI), from Eurostat, is a combination of its Industrial Confidence Indicator, Services Confidence Indicator, Consumer Confidence Indicator, Construction Confidence Indicator, and Retail Trade Confidence Indicator, each with different weights. See Eurostat, "Products Datasets," "Dataset Details," "Economic Sentiment Indicator," at http://ec.europa.eu/eurostat/web/products-datasets/-/teibs010.

${ }^{2}$ The percentages in this row reflect the arithmetic mean of the percentages for the first six months of each year.

${ }^{3}$ The percentages in this row reflect the arithmetic mean of the percentages for the second six months of each year.

SOURCE: Eurostat, "Sentiment Indicators, Monthly Data" (Seasonally Adjusted Data), 2004-2013, http://appsso.eurostat. ec.europa.eu/nui/show.do?dataset=ei_bssi_m_r2\&lang=en. 
Figure 5

Euroskepticism, Economic Sentiment, and Confidence in Klaus

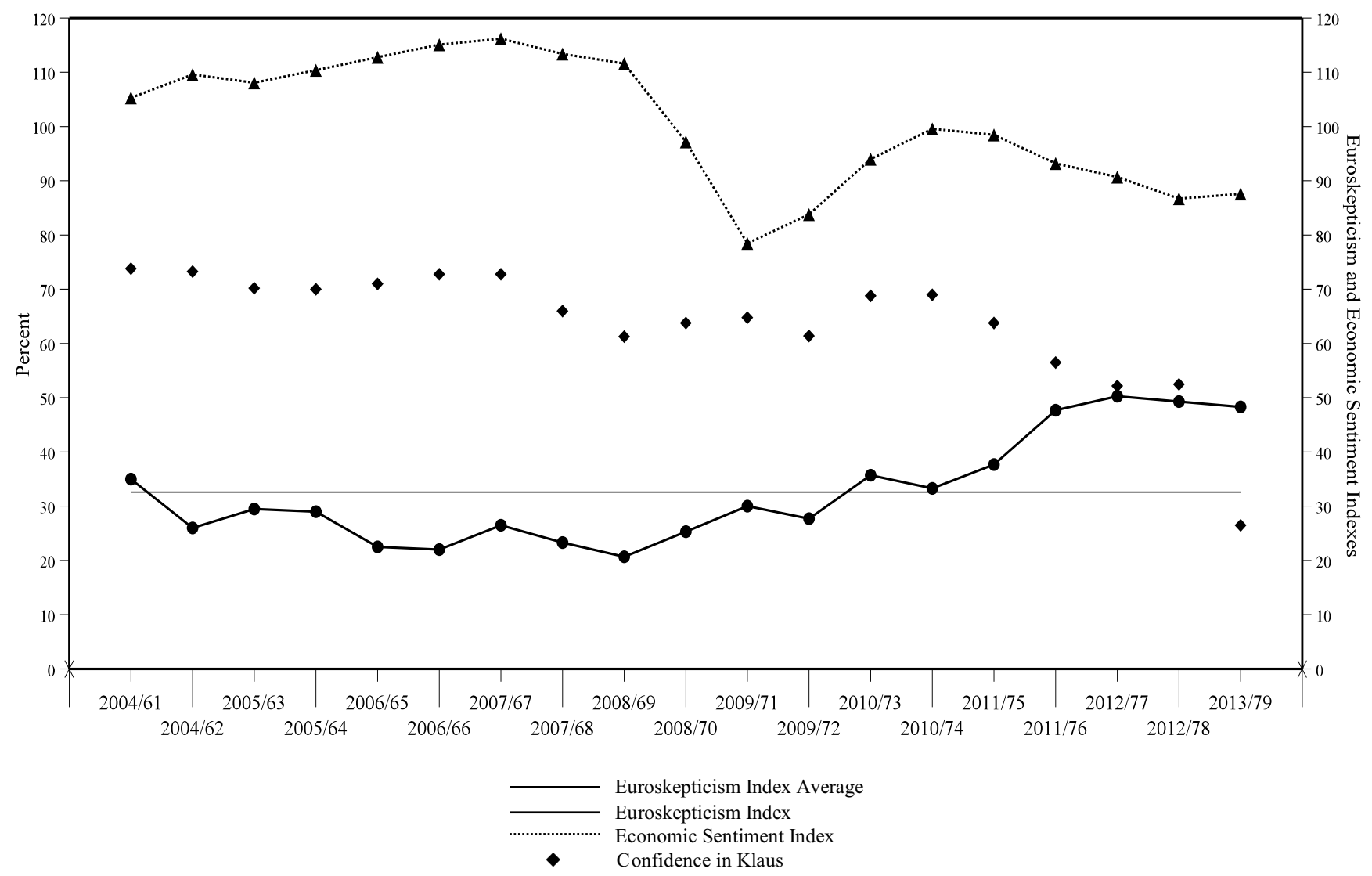

Source: The data is from Tables 2, 8, and 9. The Euroskepticism Index (EI) mean average is 32.61 percent for the time Klaus was in office (from ES 2004/61 to ES 2013/79). From 2004/61 to 2013/79, the correlation between confidence in Klaus and the EI is -0.68; from the spring of 2007 through 2010, it is 0.47 . The correlation between confidence in Klaus and the Economic Sentiment Index (ESI) from 2004 to 2013 is 0.59 ; from the spring of 2007 through 2010, it is 0.37. The correlation between the EI and the ESI from 2004 to 2013 is -0.63 ; from the spring of 2007 through 2010 , it is -0.5 
elaborated on his Euroskepticism. He often presented his criticisms of the EU using academic-like formats that were excellent means of strengthening the legitimacy of his political views in the eyes of the voters.

A team of researchers also concluded that Klaus devoted an inordinate amount of time criticizing the EU. Otto Eibl, Miloš Gregor, and Alena Macková undertook a content analysis of 470 of Klaus's speeches delivered from 1995 until he left office and since published on his website: 114 public addresses before he became president, 181 during his first presidential term, and 175 during his second term (a total of 356 as president). ${ }^{37}$ Before Klaus became president, the EU was his third most important topic, after miscellaneous matters and foreign affairs, and he spoke about it 25 times (14 percent of all topics). During his first term as president, the EU remained in third place, after foreign affairs and miscellaneous matters; but like foreign affairs, it grew in frequency: he spoke about the EU 51 times (29 percent of all topics). As a second-term president, Klaus made 60 references to the EU ( 28 percent of all topics), his most frequent subject (the theme of foreign affairs was second, and miscellaneous matters was third). His total references to the EU between 1995 and 2013 amounted to 136 (19 percent of all topics). There were nine other categories: foreign affairs other than the EU (mentioned 117 times); the domestic political situation (82 times); the economy (64 times); Czech society (55 times); sociopolitical transformation from the communist era (43 times); communism and socialism (35 times); specific policies (27 times); the ODS, his former political party (20 times); and miscellaneous matters (140 times). Excluding miscellaneous matters, the EU was the most important category overall, the second most important category before Klaus became president and during his first term, and the most important category during his second term. ${ }^{38}$ Eibl, Gregor, and Macková determined that Klaus spoke negatively about the EU 62 percent of the time and only 3 percent of the time positively. Furthermore, his opinion was weak or strong, as opposed to being neutral, before becoming president ( 40 percent weak and 28 percent strong), in his first term (29 percent weak and 25 percent strong), and in his second term (38 percent weak and 37 percent strong), with his second term exhibiting the most strength. Overall, he moralized or lectured 23 percent of the time and spoke of his accomplishments in that category only 7 percent of the time. His attitude toward the EU became progressively negative: 50 percent of time before becoming president, 49 percent in his first term, and 78 percent in his second term. He also strove to dissociate himself from the problems he claimed the EU had created. ${ }^{39}$ Eibel, Gregor, and Macková concluded that

We would search in vain [in Klaus's comments] for a model [of objectivity] or the lack of emotion regarding the European Union and the sociopolitical situation in the Czech Republic. Very few people today would be surprised that Václav Klaus criticized the European Union, but the interesting thing is that his criticism and efforts to offer alternatives, change something, or add to the issue grew over time. Interestingly, in relation to the EU, Klaus often used the pronouns "he/she/they" to create some distance from the group of actors who, according to him, were responsible for the state of affairs. ${ }^{40}$

Klaus became president in March 2003, when the EU draft constitution was not ready and 14 months before the Czech Republic joined the EU. A few of the statements Klaus made during his first year in office showed the same Euroskepticism he had expressed in the past but also indicated his future stance toward the EU. Although a known Euroskeptic before becoming president, Klaus cautiously toned down his anti-EU comments while campaigning for the presidency. That was not the case after his election. Before the June 2003 referendum on EU membership, Klaus wrote an article for a leading Czech newspaper, Mladá fronta Dnes, in which he described the entry of the Czech Republic into the EU as "a marriage of convenience [literally: reason], not love," and he warned that it will not solve all of the country's problems. ${ }^{41}$ Writing for the same newspaper four months later, Klaus advised readers that the independent states of the EU do not require a constitution, a document that would accelerate the integration that Jacques Delors (born 1925) envisioned and the Brussels bureaucrats hoped to achieve. ${ }^{42}$ For Klaus, a constitution was a matter of "crossing the Rubicon, after which sovereign states with their lawful governments, parliaments, and representatives of the legitimate 
interests of their citizens will not exist, but [instead there will be] only one state." ${ }^{43}$ In November, a BBC reporter asked Klaus about his famous remark that the Czech Republic was in danger of dissolving within the EU, like a sugar cube in a cup of coffee, and Klaus responded: "Yes, such is my fear, and I take it very seriously." ${ }^{44}$ Also in November, Klaus spoke about the euro, at the Cato Institute in Washington, DC, noting that the currency existed as a political tool to further integration that, in addition to other failings, eliminates independent monetary policies and exchange rates. ${ }^{45}$ In December, Klaus released yet another article in Mladá fronta Dnes about the draft EU constitution, in which he wrote that the bureaucrats in Brussels are pleased to weaken democratic control so that they will make all the decisions and "the citizens' voices will be silenced." Meanwhile, serving the bureaucracy will be "ambitious intellectuals" with their "ideology of ethical universalism and internationalism." 46

From January to May 2004, just before the Czech Republic became an EU member state, Klaus continued his warnings about the EU. In January, he branded the economic policies of the EU as stifling competition and economic creativity. ${ }^{47}$ In an article a few weeks later, Klaus claimed that those advancing the constitution were Europeists (Czech plural: evropeisté)-those on the left who use European integration to replace discredited socialist collectivism. ${ }^{48}$ At the same time, he delivered a lecture at the Faculty of Economics at the University of Passau, in which he outlined the difficulties and additional potential problems associated with the euro. ${ }^{49}$ In March, he was critical of a draft plan of the government that outlined the Czech Republic's involvement in the EU in the course of the next decade. ${ }^{50}$ A month later, he warned that the representatives of the Czech Republic to the EU will have to be vigilant about the country's interests, which he claimed would be difficult, given the international setting of the EU. ${ }^{51}$ On April 30, the day before the Czech Republic entered the EU, Klaus spoke about the need for Czechs to maintain their state's identity as they maneuver in Brussels and in the "complex multinational unit" that is the EU. ${ }^{52}$ Overall, Klaus criticized the EU in statements that got the attention of the Czech media more than once each month before the Czech Republic entered the EU. Additionally, in the middle of April, Klaus published Evropa Václava Klause (The Europe of Václav Klaus), a compilation containing 43 of his speeches and writings between 1993 and 2004 that largely focused on the problems associated with the EU. ${ }^{53}$

On May 1, 2004, the blue flag of the EU, with its 12 gold stars, flew over every government building in the Czech Republic, aside from one: the Prague Castle. It was Klaus's symbolic display of resistance to the EU that characterized his presidency. ${ }^{54}$ Consistent with his constant refusal to fly the EU flag at the Hrad, Klaus sustained his sometimes virulent criticisms of the EU throughout his presidency. He did not relent, even as a majority of Czechs reveled in their country's EU membership in the remaining months of 2004.

On 1 June, Klaus granted an interview to Alexandr Kramer (1946-2012), a noted author and journalist with the daily Právo, during which he said that Europeism (Czech: evropeismus) is a concept of the left, not the right. ${ }^{55}$ Over the years, Klaus often repeated this notion to such an extent that he seemed to imply that the existence of some sort of leftist conspiracy. Speaking at the Ludwig Maximilian University of Munich in June, less than two weeks after the unveiling of the draft EU constitution, Klaus noted that the recent expansion of the EU resulted in several difficulties, including a heightening of the democratic deficit and "hierarchical decision making." ${ }^{56}$ In August, at the European Forum, an organization of civic leaders and members of the European Parliament, Klaus repeated some of the concepts he had expressed in Munich, and he warned that rapid economic integration and the increasing democratic deficit in an entity as large as the EU may backfire. ${ }^{57}$ On September 1, at a gathering of Czech diplomats at the Prague Castle, Klaus admonished them to bear in mind three things about the EU: membership in it does not make states European; integration must advance a free market and the free movement of goods, people, and capital, without strengthening the "Brussels bureaucrats"; and states must function, within the EU, to further their own interests and to reduce the democratic deficit. ${ }^{58}$ At the end of the month, he predicted that Turkey, which had become a candidate member of the EU in 1999, would not be interested in an "ambitious Delors-Maastrict constitution." 59 
In the last quarter of 2004, Klaus focused on his concept of Europeism. On October 20, when addressing the Bruges Group, a think tank opposed to European integration, Klaus viewed the EU as becoming less democratic and more bureaucratic. He criticized the draft constitution for the EU as arising from the ideology of Europeism, which he further defined as comprising several faulty convictions: the continent has a past collective identity that it should cultivate; Europe has a common history; homogenization is desirable; competition is unfair, unproductive, and harmful to groups and societies; centralization and bureaucratization of a larger Europe will result in a stronger Europe; regulation, which big markets make essential, prevents market failure; and regulators from the EU are less responsive to special interests than national regulators, making large government remote from the citizens preferable to national governments. ${ }^{60}$ During an interview, on November 16, with the influential Czech newspaper Hospodárské noviny, Klaus stated that those who support the EU draft constitution are "Euro-naive and Eurofanatics" who link the constitution to the very existence of the EU. ${ }^{61}$ Four days later, at the European Forum in Berlin, Klaus decried "an artificially accelerated unification of the continent" but still desired free movement of people, goods, services, and capital, along with the lack of restrictions on competition. He openly opposed "bureaucratic institutionalization" and the "idea of "ever closer union." "He reiterated his desire to avoid the elimination of countries and states in favor of "EU structures that lack sufficient democratic accountability." 62 When welcoming the president of Poland to the Czech Republic in early December, Klaus claimed that "Czech and Polish historical experience compels us not to forget the risks that can come with the artificial acceleration of European unity at the expense of the existence of nation states for the sake of the coexistence of very different countries in one multinational institution." ${ }^{63}$ In Právo, he told Kramer, during another interview, that the draft constitution for the EU is "a serious danger and threat" and that, with it, "Europe will lose." 64

In his 2005 New Year's speech, Klaus reminded Czechs that, in the past year, they had voted for members of the European Parliament, representatives of the people who "again [were] sent abroad from our country after nearly a century (the last ones were our representatives in the Viennese diet). ${ }^{965}$ His phrasing implied that the European Parliament will be as dysfunctional and unresponsive to Czech needs as the Austrian Reichsrat of the latter years of the Habsburg Monarchy. As the political scientist Jiří Pehe noted some years later, Klaus "effectively used Czech fears of outsiders' political meddling to portray the EU as 'they' who wanted to dictate to "us." "'66 Between May and December, Klaus maintained his rate of one high-profile speech per month in which he took stabs at the EU. With the authority of the presidency behind him, it is not surprising that Klaus's comments eventually began to resonate with his fellow citizens.

In the first year of Klaus's presidency, there was a negative relationship between confidence in Klaus and the EI. Trust in Klaus remained steady, and the victories of the ODS, his former political party, in the June 2004 elections to the European Parliament and the November 2004 elections to the Czech Senate, seemed to have no significant impact on his confidence rating. Meanwhile, the EI dropped dramatically, from 35.0 to 26.0 points, likely a response both to the country's entry into the EU, which Czechs widely viewed as an important and desirable foreign-policy objective, and to the country's pride resulting from its first experience with elections to the European Parliament. Then, in the first half of 2005, the EI rose slightly and remained steady for the rest of the year, while trust in the presidency essentially paralleled the EI. Klaus may have begun to win adherents to his point of view, considering that there appeared to be no intervening variables and assuming that the trend was more than mere coincidence (see Figures 4 and 5).

In the first five months of 2005, Klaus redoubled his efforts to promote Euroskepticism, writing and speaking 13 times about various aspects of the EU. Four of those instances were with major Czech newspapers. In January, he stated, in an interview for the Fraser Forum, a journal of the conservative Fraser Institute in Canada, that "for us, the entry to the EU was a marriage of convenience, not of love," repeating his 2003 message to Czechs. He added that the "“ever closer Union' is a problematic paradigm" and that democracy cannot function without nation-states. ${ }^{67}$ In February 2005, the first referendum on the EU constitution took place in Spain, after legislatures elsewhere in Europe had begun voting on the EU constitution during the last 
months of 2004. Meanwhile, Klaus devoted a great deal of effort to prepare the ground for a defeat of the EU constitution in the Czech Republic. In the Frankfurter Allgemeine Zeitung, he condemned what he termed the second phase of EU development, which he associated with the work of Delors and the Maastricht Treaty, as undemocratic and "postdemocratic." At the time, Klaus claimed that he did not want to turn back the clock on the EU, but he opposed a constitution and hoped to delay further integration. ${ }^{68}$ In a foreword to a CEPu publication about the EU constitution, Klaus deemed the document that was to make Europe one state "too long, too complicated, and for mere mortals, an unintelligible text." ${ }^{\text {69 }}$ On May 26, because Klaus criticized the EU constitution in foreign venues, while the government supported the draft EU constitution, the Social Democratic prime minister, Jiří Paroubek (born 1952), threatened that the Foreign Ministry might withhold approval for Klaus's trips abroad. The president's office retorted that Klaus was within his constitutional right to make statements about foreign policy and that the government may not hold the president prisoner in the country. The two reached an amicable solution, and Klaus's travels continued. ${ }^{70}$

With the voters' rejection of the draft EU constitution in France, on May 29, and in the Netherlands, on June 1, the initiative was dead, and Europe entered a so-called period of reflection. Klaus wanted to set every nail firmly in the coffin of the EU constitution not only in the Czech Republic but also abroad. He undertook a flurry of articles, interviews, and speeches, for both domestic and foreign consumption, throughout the remainder of the year-16 in all, with eight articles in major Czech newspapers and one television interview. He told readers of Lidové noviny that the Europeists wanted a single European nation and culture but that Europe did not need "unification, harmonization, and centralization." Cooperation among European states required a natural evolution, according to Klaus, not some entity that politicians envision. Klaus proposed the creation of a new Organization of European States, devoid of an ideology advancing integration, in order to promote the common interests of individual countries. ${ }^{71}$

The Czechs' confidence in the presidency improved slightly in May 2005, and in June, after the French and Dutch had defeated the draft EU constitution, trust increased again. ${ }^{72}$ Throughout 2005, confidence in the presidency was steady, averaging 70.2 percent in the spring and 70.0 percent in the autumn. Klaus's popularity ratings rose somewhat, as the year progressed, moving from 63.5 percent in the first half of the year to 65.0 percent in the second half, a change that was statistically negligible. The EI held steady at 29.5 and 29.0. In 2005, CVVM conducted three surveys of Czechs to gauge their perceptions about the draft EU constitution. Although the percentage of supporters saw very little change in February and April, moving from 56 percent to 58 percent, it dropped to 41 percent in June, after the constitution's defeat in the Netherlands and France. Many respondents might have wanted to be on the winning side of the issue, but the two defeats of the constitution also lent credibility to Klaus's message. The percentage of those opposing the constitution also climbed, from 21 percent in February to 26 percent in April. Then, in June, it stood at 34 percent, 4 percent below distrust in the EU, but it was well above the negative image of the EU, which was 20 percent. The June figures showed that the pace at which Czechs were moving to the undecided category and to the group opposing the draft EU constitution quickened, as the number of those who favored it dwindled. ${ }^{73}$

In 2006, the EI declined, hovering around 22 points for the year. At the same time, Klaus's confidence rating remained statistically unchanged, and the victories of his former political party, the ODS, in the June legislative elections seemed to have no impact on the numbers. In fact, after the ODS won a plurality of votes in the October Senate and municipal elections, confidence in Klaus decreased four points, suggesting that Czechs saw the association between Klaus and the ODS as weak, at best (see Table 2). In 2006, Klaus went to the media twice with his anti-EU campaign. In March, he gave an interview to Der Spiegel that outlined his misgivings about the deepening integration of the EU, which, at one point, he compared to communism under Leonid I. Brezhnev (1906-1982). ${ }^{74}$ Klaus's most significant work that year was an article in an April issue of Mladá fronta Dnes, explaining his concept of Europeism. He noted that its "arrogant authoritarianism, with its intolerant ... political correctness," was actually a combination of ideas. Europeists distrust the free market and prefer a regulated one, improperly assuming that the government can interfere successfully in the market. 
They want to "harmonize and homogenize" countries, instead of focusing on reducing barriers to the free movement of goods, capital, and people. Their restrictions of the free market hamper competition and increase costs, making EU countries less competitive. Klaus maintained that Europeists are abandoning the principles of Jean Monnet (1888-1979), considered the founder of the EU, in favor of those of Delors, whose notions have the backing of a narrow elite of Eurocrats and like-minded politicians and intellectuals. Europeists support such beliefs as multiculturalism, feminism, ecologism, homosexualism, and NGOism. They also want to make decisions at the supranational level, without the input of the citizens of individual states. Finally, Europeists believe in trusting chosen administrators, who advance a planned and regulated society that they present as a utopia, instead of elected officials. ${ }^{75}$

In 2007, the trust of the Czech president began its period of positive correlation with the EI that lasted well into 2010. In January 2007, after Germany had assumed the presidency of the EU and had vowed to move forward with an alternative to an EU constitution, Klaus wrote an article for Mladá fronta Dnes, criticizing the "ever-closer, increasingly interconnected, ever more united, ever more 'harmonized' and 'standardized,' ever more managed-from-the-top, regionalized, and coordinated Europe," in which the historic states give way to an undemocratic supranational organization employing the "person-cast-aside" model. As an example, he cited the former German president's statement that 80 percent of German legislation comes from Brussels. The proposal for some kind of EU constitution intensified what Klaus believed was a disastrous process. Instead, he suggested that the member states devise some kind of document to stop "creeping unification." 76 In the middle of June, on the eve of the meeting of the European Council that deliberated an alternative to a constitution, Klaus warned, in Hospodářské noviny, that whatever comes of it will be substantially the same as the constitution that voters in the Netherlands and France had rejected. The difference would be that the new proposal would not require referenda. ${ }^{77}$

Throughout 2007, Klaus gave five interviews, during which he was critical of the EU. In January, in the Polish daily Dziennik, and in February, in Hospodárské noviny, Klaus dismissed the desirability of a constitution for the EU. ${ }^{78}$ In June, in an interview for the Frankfurter Allgemeine Zeitung that later appeared in a Czech newspaper, he criticized the EU's democratic deficit. ${ }^{79}$ Four days later, he spoke on TV Prima about his reservations concerning the European Council meeting in Brussels. ${ }^{80}$ On July 3, Klaus said, in the Polish newspaper Rzeczpospolita, that the "centralization of the decision-making process in the EU" was the greatest threat to Europe. He also was critical of immigration to Europe and reiterated his distaste for "-isms," like homosexualism and feminism. ${ }^{81}$

In May 2007, Klaus published his book about climate change, titled Modrá, nikoli zelená planeta (published in English as Blue Planet in Green Shackles), in which he claimed, among other things, that global warming was the brainchild of a minority of career-minded academics and liberal politicians who find it a convenient means of gaining votes in certain quarters. ${ }^{82}$ He branded it a mistaken belief that harms not only the economy but also personal freedoms. In critiquing the book, the academic and politician Pavel Nováček (born 1961) noted that "Klaus is president of the Czech Republic, and therefore his book can have a considerable influence on the population. The office of the president in our country enjoys great esteem, regardless of the person who actually occupies the post." ${ }^{\prime 3}$ During a meeting with business leaders, Klaus spoke against the euro, arguing that it was unsuccessful, and he dismissed the idea of a "good" euro and a "bad" Czech crown. ${ }^{84}$ Finally, in the spring of 2007, Klaus made headlines for his opposition to the design of Jan Kaplický (19372009) for the new National Library (the Ministry of Culture cancelled the project the next year). ${ }^{85}$ It is possible that his downturn in popularity and confidence, in subsequent CVVM surveys, was related to his standpoints on these issues. At the same time, the Euroskepticism Index, based on the spring SE, also dropped. Then, in the first half of 2007, the ES index for the Czech Republic also declined slightly.

The controversy surrounding the Treaty of Lisbon motivated Klaus, from December 2007 through 2009, a time that falls within the period of positive correlation between confidence in Klaus as president and the EI. On December 13, 2007, the Czech government, under Mirek Topolánek (born 1956) of the ODS, signed the 
Lisbon Treaty, which instituted the double majority procedure and created both the offices of the President of the European Council and the High Representative of the Union for Foreign Affairs and Security Policy. ${ }^{86}$ In early 2008, Klaus ran for reelection, and in his first speech as a candidate, he tempered his Euroskepticism, explaining that he supported the EU but did not want the Czech Republic to lose the freedoms it had won after the fall of communism. He desired a better-functioning EU, with the Czech Republic playing an active role in it. ${ }^{87}$ Klaus won the election, on February 15, by one vote, amid accusations of corruption. ${ }^{88}$ Then, in March, newspapers reported that he had indulged in an extramarital affair (there were two other rumored affairs in 1991 and 2002). Neither of these controversies seemed to hurt Klaus: confidence in the presidency actually marginally increased, although in May 2008, in the first poll after his election and news of his affair, his popularity stood at 58 percent, six points below his December 2007 rating. In April 2008, the Senate had asked the Constitutional Court to review the Treaty of Lisbon to see if it contradicted Czech law, and on June 3, Klaus supplied the court with a long explanation of his position against the treaty, which he claimed harmed Czech sovereignty. ${ }^{89}$ Klaus turned his words into action when he vetoed two laws that had drawn their inspiration from EU legislation. In May, considering it redundant, he vetoed an antidiscrimination law that was an EU effort to create umbrella legislation to prevent discrimination. In August, he vetoed another EU-based measure to regulate the chemical industry because he deemed its provisions burdensome. ${ }^{90}$ During an interview in the summer, Klaus predicted that the integration process of the EU would hit a "blind alley" and come to an end.91 On October 13, the Polish newspaper Rzeczpospolita published an interview with Klaus. He emphasized that progress toward creating a unified EU, at the expense of the individual states, was "an absolute tragedy" and that he rejected the notion of euroregions, which he claimed were "the end of the world." Klaus also spoke against the Treaty of Lisbon as "only a cosmetically revised version" of the EU constitution. ${ }^{92}$ Shortly after the interview, Klaus's former party again won the October Senate elections, which had no bearing on the government's position toward the Treaty of Lisbon. Then, on November 25, Klaus publically addressed the Constitutional Court about his position that "the Lisbon Treaty does not comply with the constitutional order of the Czech Republic" and that it "violates the constitutional principle of the sovereignty of the Czech people." 93 The next day, the Constitutional Court unanimously decided that the concerns of the senators and Klaus were unfounded. Three days later, Klaus speculated, in Mladá fronta Dnes, that no judges took an opposite stance because "they would then be forced to write a minority opinion. That's work, and no one wants to do it." was a weak rationale for explaining the judges' like-mindedness.

In October 2008, the Great Recession began that shattered the faith in financial and political institutions worldwide. To gauge the impact of the crisis and the economy in general, this study employs Eurostat's Economic Sentiment Index (ESI), a weighted combination of five indexes that provides a sense of what inhabitants think about the economy (see Table 10 and Figure 5). Until the beginning of 2007, the ESI for the Czech Republic registered an overall increase, then it began a slight decline. In the last quarter of 2008, which was the beginning of the recession, it dropped precipitously, reaching its lowest level in February 2009. The second half of 2008 brought a rise in the EI, from 20.7 to 25.3 points, marking the start of an upward trend that lasted three and one half years and that peaked only in the first half of 2012 . While the EI had a generally downward trend from 2004 to 2008, and the ESI, for the same period, tended to tick upward gradually, the second half of 2008 marked a turning point for both. The EI began rising, although it remained below its average for 2004-2014, but the ESI descended at rapid rate. In the third quarter of 2008, Klaus's confidence ratings and popularity also fell somewhat, most likely due to the economic downturn - a phenomenon all world leaders experienced at the time - and his judicial defeat on the Lisbon Treaty. Nevertheless, his average for the second half of 2008 actually was slightly higher than for the first half of the year, but the difference is inconsequential. So, while the ESI decreased and Euroskepticism increased, the trust Czechs had in their president held firm, perhaps because they may have felt that the recession had proven Klaus was correct in his warnings about the EU and the euro. 


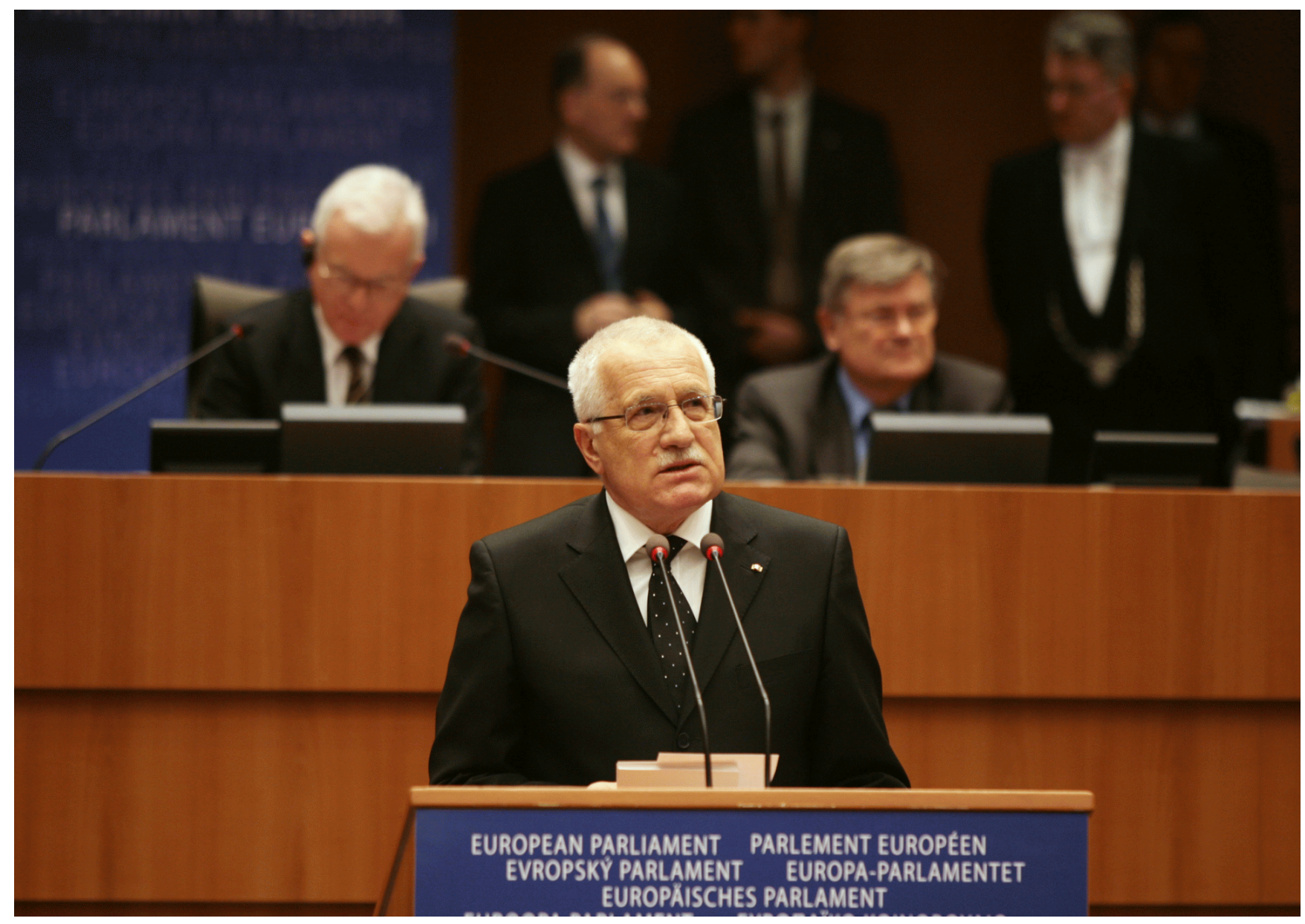

Václav Klaus at the European Parliament, 19 February 2009. Photo: Institut Václava Klause. 
For the first half of 2009, the Czech Republic was to hold the presidency of the Council of the European Union, and in December 2008, the chairman of the European Parliament and the leaders of all the political groups in the chamber had a ceremonial meeting with Klaus. In the opening moments, the leaders of the European Social Democrats, the Alliance of Liberals and Democrats for Europe, the Greens, and the European Free Alliance pressed Klaus about ratifying the Treaty of Lisbon. The leader of the Greens, Daniel CohnBendit (born 1945), asked what connections Klaus had with the Irish businessman and politician, Declan Ganley (born 1968), whose finances were murky and who had resisted the Lisbon Treaty. ${ }^{95}$ Klaus retorted,

I must say that, up to now, nobody has spoken to me in the past six years with this style and tone. Here you are not on the barricades of Paris. I thought these methods [of negotiations] had ended for us 18 years ago [with the fall of communism]. I see that I was wrong. I would not dare to ask you how the activities of the Greens are funded. ${ }^{96}$

The pressure on Klaus continued, and he repeated, "I did not expect, that something like this is possible, and over the last 20 years, I have not experienced anything like it. I thought that it belonged to the past [and] that we lived in a democracy, but the EU truly functions as a postdemocracy." ${ }^{97}$ Klaus had made obvious references to the Soviet Union and its dictates to Czechoslovakia before 1989, but when the chairman of the European Parliament, Hans-Gert Pöttering (born 1945) deemed the comparison "unfriendly," Klaus contended that he never had mentioned the Soviet Union by name. ${ }^{98}$ When Klaus spoke at the European Parliament, on February 19, 2009, he took the opportunity to present a rebuttal. He challenged its members to continue removing barriers to free trade and movement in the EU, without affecting the sovereignty of its member states. He advanced his belief that people's freedoms and a free market are the only guarantees to prosperity. Finally, he decried the growing democratic deficit in EU procedures. ${ }^{99}$ Not long afterward, during a talk he gave in Germany, Klaus noted that "the post-Bismarckian social system [as well as] the needlessly high energy costs and the reduction of energy alternatives on the basis of irrational environmental ideas slow down the economy." 100 On June 5, elections to the European Parliament took place, and the ODS emerged with a plurality of seats. That victory may have contributed to a boost in Klaus's confidence rating, which had fluctuated between 65 and 67 percent in the first four months of the year, and then it had slid to 61 percent in May, only to jump to 66 percent in June. ${ }^{101}$ More likely, the boost was a response to the appointment, in early May, of a government of bureaucrats under the statistician Jan Fischer (born 1961). The public had been disgusted with the politicians' bickering after a March vote of no confidence in the government, and it welcomed the nonpolitical cabinet, which strengthened the president's hand. Later, the Constitutional Court's cancellation of early legislative elections scheduled for September 2009 may have added to the minor 2 percent decline for Klaus. ${ }^{102}$

The Chamber of Deputies easily approved the Lisbon Treaty on February 18, 2009, and on May 6, 2009, the Senate did the same. Nevertheless, Klaus did not sign it, and in September a group of senators initiated another procedure against it in the Constitutional Court. On October 9, Klaus announced that the treaty "will deepen the problems EU is facing today, it will increase its democratic deficit, worsen the standing of our country, and expose it to new risks. ... It endangers the legal status of the citizens and the stability of property rights in our country." He was concerned that, with the Charter of Fundamental Rights of the European Union that was to take effect with the Treaty of Lisbon, the European Court of Justice could overturn the Beneš Decrees that had expelled the Germans from Czechoslovakia after the Second World War and confiscated their property. ${ }^{103}$ In October, Klaus and the EU negotiated an opt-out provision for the Czech Republic, with respect to the Charter of Fundamental Rights, and Klaus promised to sign the Treaty of Lisbon if the Constitutional Court decided that it was compatible with the Czech constitution. ${ }^{104}$ As the Constitutional Court considered the case, Klaus published his examination of the post-communist era, Kde začíná zitřek (Where Tomorrow Begins). Toward the end of the book, Klaus reiterated his misgivings about developments in the EU and the problems they could entail for Europe and the Czech Republic. ${ }^{105}$ In early November, the Constitutional Court announced $-30-$

The Carl Beck Papers in Russian and East European Studies http://carlbeckpapers.pitt.edu | DOI 10.5195/cbp.2017.219 | Number 2503 
that the Lisbon Treaty did not conflict with Czech laws. Klaus unceremoniously signed the treaty, on November 3, but he objected to it in a formal statement. ${ }^{106}$ Pehe considered this "the greatest defeat of Václav Klaus during his political career." 107 Nevertheless, the drop in confidence the Czechs had in the presidency that month was minimal.

As the debate in the Czech Republic over the Treaty of Lisbon raged throughout 2008 and 2009, Eurobarometer conducted four scheduled SE surveys. In the first three, the distrust for the EU, the negative image of the EU, and the belief that the EU was headed in the wrong direction increased. As a result, the EI rose steeply. STEM, a Czech polling firm, conducted three surveys in 2008 that asked Czechs whether they thought parliament should approve the Treaty of Lisbon, and the total supporting the treaty dropped from 52 percent in February to 45 percent in October, while the total opposing the treaty heightened, in the same period, from 48 percent to 55 percent (see Table 10). According to 2009 CVVM surveys, resistance to and support of the Treaty of Lisbon increased from January to June as the undecided voices diminished: resistance jumped from 19 to 30 percent, and support climbed from 33 to 35 percent. Both fell a bit in the April survey, not long before the Senate voted to approve the treaty. Those who abandoned their position did not switch camps but moved to the undecided block, which spiked at the time, breaking what otherwise was a steady reduction in the number of undecided citizens. In October, just before the Constitutional Court issued its ruling, which many had expected would find no difficulties with the Treaty of Lisbon because of the court's past decision on the treaty, support for the treaty rose: 43 percent of Czechs strongly or mildly supported the treaty, 27 percent strongly or mildly opposed it, and 30 percent were undecided. ${ }^{108}$ STEM surveys of January and February 2009 partially agreed with the trends the CVVM had discovered. STEM found that support dropped from 64 to 60 percent, which mirrored the CVVM's conclusions, but it also found that resistance had increased from 36 to 40 percent, which contradicted the CVVM's data. Unlike the CVVM, however, STEM did not offer respondents the option to remain undecided. Nevertheless, the majority of Czechs STEM polled in January and February 2009 supported the Lisbon Treaty, which reversed the sentiments of June and October 2008 (see Table 10). The finding of the Constitutional Court and Klaus's signing of the Lisbon Treaty occurred four days before the surveying began for the autumn 2009 SE and ten days before it ended. The results of SE 2009/72 indicate that negativity decreased and that the Euroskepticism Index diminished slightly. Conversely, trust in the EU, the positive image of the EU, and the opinion that the EU was proceeding in the right direction all moved upward (see Tables 5, 6, and 7). While Klaus may have had some influence on Czech opinion toward the Treaty of Lisbon, a convergence in the views of other significant political actors-both chambers of the legislature and the Constitutional Court-may have weakened his appeal.

In 2010, as the global economy sluggishly recovered from its recession, Klaus persisted in his criticisms of the EU and escalated his campaign against the euro. Throughout the year, his writings and interviews on these subjects appeared ten times in various Czech periodicals. In April, Klaus predicted that the euro would not collapse, even though he maintained that the eurozone was not an optimum currency area, because its creation had been a political decision. ${ }^{109}$ When Klaus rhetorically asked, during a speech at Humboldt University of Berlin, whether the Treaty of Lisbon would bring Europe more democracy, freedom, and prosperity, he responded, "My answer is: never." "In May, he criticized the power of the EU bureaucracy, stating that, in the nineteenth century, "Bismarck- and Metternich-type politics controlled Europe, and we have returned to that today." 111 When one interviewer challenged Klaus, pointing out that most Czechs rejected his standpoints on the EU and global warming, he took exception to the claim and argued that the number of those who agreed with him is growing, particularly in light of the threats against the euro. ${ }^{112}$ In July, Klaus lamented that many Europeans rejected capitalism and the market economy without comprehending their indispensable contribution to Europe's prosperity. ${ }^{113}$ In September, he argued that the EU put politics before economics, which was similar to the socialist experiment in the former Soviet Bloc. ${ }^{14}$ He considered the euro "a dangerous prospect" that "will give rise to economic problems or lead to an undemocratic [and] centralized Europe." 115 


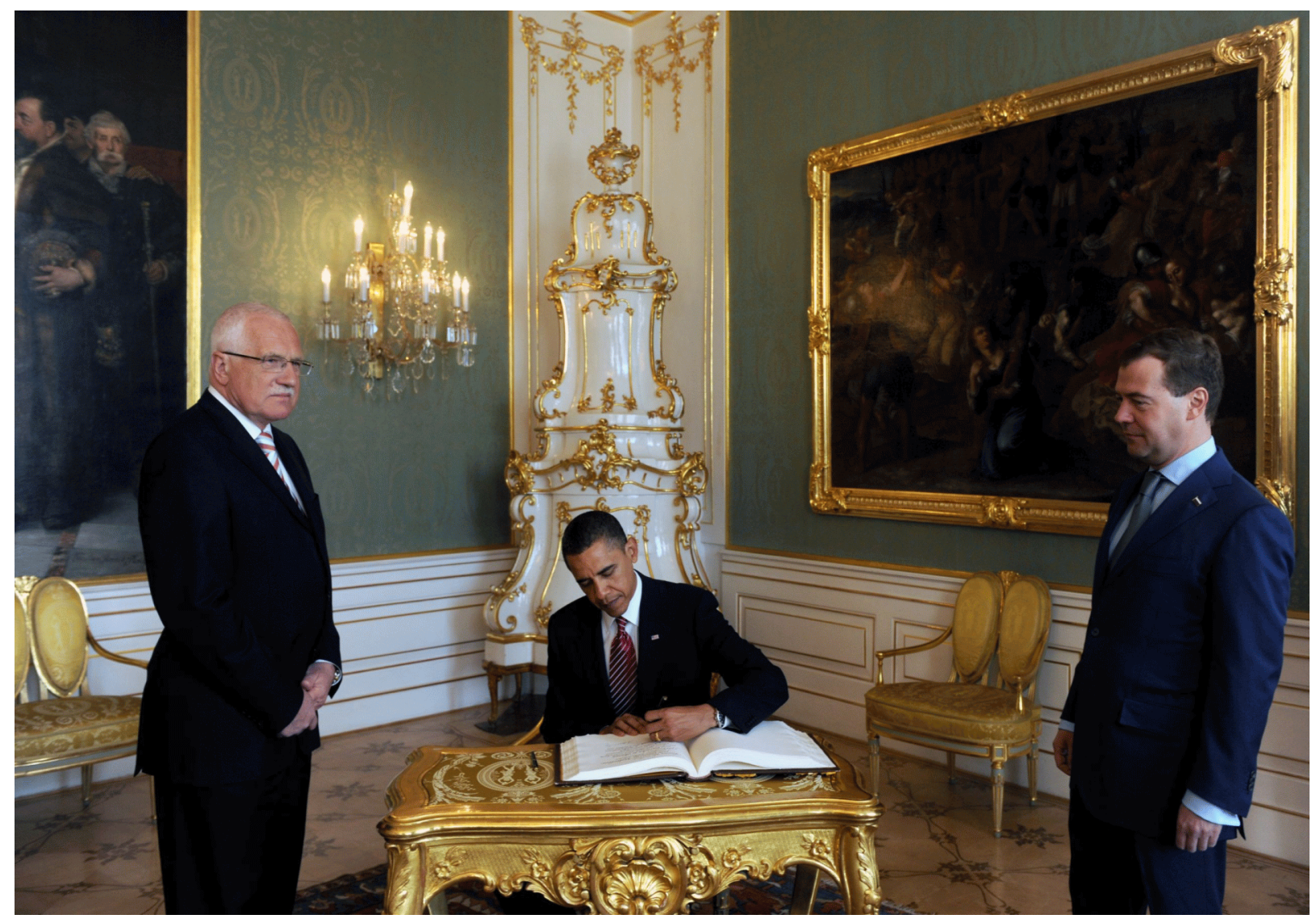

Václav Klaus (left) and Dmitry Medvedev (right) watch Barack Obama sign the new Strategic Arms Reduction Treaty, 8 April 2010, at Prague Castle. Photo: Institut Václava Klause. 
Table 10

Czech Sentiments Regarding Passage of the Treaty of Lisbon (percent)

\begin{tabular}{|l|c|c|c|c|c|}
\hline \multicolumn{1}{|c|}{ Answer } & February 2008 & June 2008 & October 2008 & January 2009 & February 2009 \\
\hline Definitely Yes & 7 & 7 & 7 & 15 & 12 \\
\hline Rather Yes & 45 & 40 & 38 & 49 & 48 \\
\hline Rather No & 39 & 38 & 41 & 28 & 29 \\
\hline Definitely No & 9 & 15 & 14 & 8 & 11 \\
\hline Total Yes & 52 & 47 & 45 & 64 & 60 \\
\hline Total No & 48 & 53 & 55 & 36 & 40 \\
\hline
\end{tabular}

SOURCE: Středisko empirických výzkumů (STEM s.r.o.), "Každý druhý občan ČR si myslí, že by parlament měl ratifikovat Lisabonskou smlovu. Jen pětina lidí však této smlouvě rozumí," February 2008; "Pro ratifikaci Lisabonské smlouvy je v současnosti $47 \%$ našich občanů. Jen $23 \%$ lidí však této smlouvě rozumí," June 2008; "Rozpaky nad Lisabonskou smlouvou trvají: Odpůrci se rekrutují především z řad těch, kteří věci nerozumějí," October 2008; "Výrazný posun v názorech na Lisabonskou smlouvu: Většina lidí si myslí, že parlament by Lisabonskou smlouvu schválit měl," January 2009; and "Většina lidí by dnešní rozhodnutí sněmovny ohledně ratifikace Lisabonské smlouvy schválila," February 2009, www.stem.cz. The question put to respondents was: "Do you think that the Parliament of the Czech Republic should approve the so-called Lisbon Treaty, replacing the originally proposed European constitution?" In February 2010, STEM asked respondents, “Are you personally satisfied that the Czech Republic adopted the Lisbon Treaty of the European Union?" The response was as follows: definitely yes, 14 percent; rather yes, 50 percent; rather no, 25 percent; and definitely no, 11 percent. "S přijetím Lisabonské smlouvy je většina Čechů spokojena, problémy s jejím schvalováním v ČR však náš obraz v EU podle poloviny občanů poškodily," February 2, 2010, www.stem.cz.

$-33-$

The Carl Beck Papers in Russian and East European Studies http://carlbeckpapers.pitt.edu | DOI 10.5195/cbp.2017.219 | Number 2503 
A major international event in 2010 likely provided a boost to Klaus's confidence and popularity ratings and served to maintain them for several months. On April 8, Klaus hosted Russian president Dmitry A. Medvedev (born 1965) and American president Barack H. Obama (born 1961) at Prague Castle, where they signed the "Measures for the Further Reduction and Limitation of Strategic Offensive Arms Treaty," also known as the New Strategic Arms Reduction Treaty (New START). Obama and Klaus held a brief private meeting afterward. In the CVVM annual survey of Klaus's performance as president, those who believed that Klaus represented the country abroad well or very well jumped from 63 percent in January 2010 to 74 percent a year later. ${ }^{116}$ Parliamentary elections took place in May, and although the ODS lost, Klaus's former party managed to form a coalition cabinet and to stay in power. In the October Senate elections, the Social Democrats won, although the ODS narrowly edged them out in the concurrent municipal elections. While there was no survey to gauge the confidence in the presidency after the May elections, such a poll took place in November. Klaus experienced a six-point increase, which likely was not a reflection of his former party's political successes. In 2010, Klaus enjoyed the highest confidence ratings since 2007. Simultaneously, the ESI continued to rise, but the EI also continued its ascent.

A number of factors contributed to Klaus's decline in popularity and trust, starting in 2011 and continuing into 2013. ${ }^{117}$ In February 2011, Klaus supported Ladislav Bátora (born 1952), a Euroskeptic and deputy minister of schools, who eventually resigned in October because of the popular outcry over his association with racist and neo-fascist movements. During a trip to Chile in April 2011, Klaus appeared to be stealing a pen while sharing the television screen with the Chilean president. It turned out that he only had pocketed a pen from the Czech Ministry of Foreign Affairs, but the incident made him look foolish and tarnished his image. ${ }^{118}$ Also in April, Klaus was involved with domestic political debates when he opposed the premier by not approving the resignation of one minister and the dismissal of two others. His rating fell nine points the next month. In July, he refused to undergo a security screening at the entrance to Australian Broadcasting Corporation studio at Parliament House in Canberra, claiming it was not befitting a head of state, and he left the premises, without having participated in a scheduled interview. From August 10-13, when a gay pride festival took place in Prague, Klaus's spokesman, Hájek, criticized the event and referred to homosexuals as "deviant citizens." In the subsequent uproar, diplomats in Prague signed a petition supporting the parade, and Klaus issued a statement backing Hájek. ${ }^{119}$

Meanwhile, there was a deepening of the economic crisis in Greece, which had begun in 2009, when the country could not meet its sovereign debt payments. The next year, its debt received junk-bond status. In 2011, the European Financial Stability Facility arranged a loan for Greece, on the condition that it enact drastic austerity measures. This prompted tens of thousands of Greeks to protest in the streets. On August 27, during an interview with the Czech newspaper Právo, Klaus remarked about the situation in Greece:

Every country should decide whether it wants to live at full speed, quarter speed, or on full speed, given its capability. It should say to itself: we will sit more hours in the shade of cypress trees and drink ouzo or work more. If Greece decides that it will devote more hours to ouzo or cypress trees, then that is fine. At the same time, it cannot enter into a monetary union with Germany. ${ }^{120}$

The international reaction to Klaus's comments, in some quarters, especially in Greece, was outrage. Many Czechs were embarrassed, and Klaus's popularity, having declined somewhat from the year before, plummeted 11 percent, between March and September 2011, to reach the lowest point to date. At the same time, trust in the office of the president fell 13 points.

Throughout the course of 2011, Klaus continued to criticize the EU, his statements becoming more vitriolic. He argued that Greece could be expelled from the eurozone because the Greek exchange already was devalued and that in 1993 the Czechs and Slovaks had handled a currency separation without "panic and dictatorship." ${ }^{\prime 21}$ During an interview for Forbes magazine, Klaus stated that "the European Union today kills 


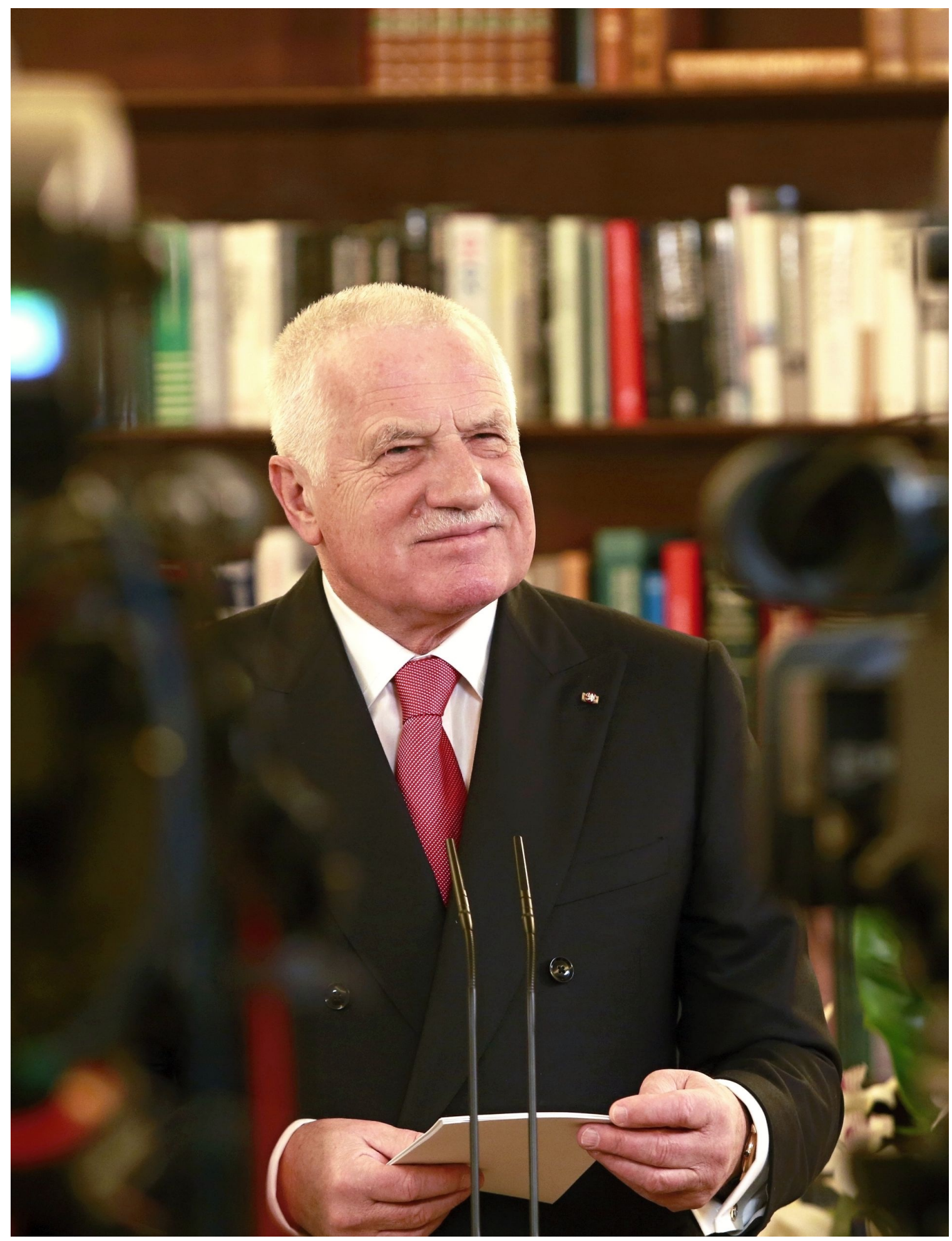

Václav Klaus giving his 2013 New Year's Day address, during which he granted his controversial amnesty. Photo: Institut Václava Klause. 
every chance for change. The process of integration has succeeded in liquidating democracy on the European continent. Today, there is often talk about the democratic deficit." Klaus's solution was to alter the nature of European integration: "we would have to go back." He continued, "European politicians are taking advantage of the current crisis so that they can complete an additional level of European integration." 122 In November, he released Evropská integrace bez iluzi (it appeared in English as Europe: The Shattering of Illusions), a book that traced the evolution of the EU and recommended a return to its pre-Delors and pre-Maastricht roots, that is, before it had strayed from all liberal principles and turned to supranationalism, Klaus's term for the elimination of democracy in favor of elite control, excessive regulation, and other anti-market notions. ${ }^{123}$ At the book launch, he said that "the European Commission and other EU organs do not believe in people's freedom or the market." 124

Klaus's biannual average ratings for the spring and autumn of 2012 held steady at 52 percent. In January 2012, the European Fiscal Compact that set strict requirements for deficit and debt for EU member states, among other things, was ready, and Klaus indicated that he would not sign the treaty, thus temporarily ending the process of ratification in the Czech Republic. ${ }^{125}$ In February and April 2012, the Senate refused to approve two of Klaus's nominees to the Constitutional Court, and Klaus's popularity suffered a slight dip. Even an assassination scare, which occurred when someone shot at Klaus with an airsoft pistol in September 2012, did not reverse the descent. Elections to the Senate in October resulted in a victory for the Social Democrats, and Klaus's former ODS party finished second; the ODS also lost the regional elections. In the second week of November, the government passed an unpopular law that restored property to the Catholic Church. Klaus waited to sign it, and as it sat on his desk, the CVVM poll registered a slight temporary increase in the confidence the Czechs had in the presidency. After two weeks passed, the bill became law, without the signature of Klaus, who said that he had some reservations about it but did not want to further belabor the matter. In early December, as polling for the CVVM was taking place, Klaus did not sign the European Stability Mechanism (ESM), enabling the eurozone members to shore up financially unstable member states, that the Senate had passed in April and the Chamber of Deputies had approved in June. ${ }^{126}$ Klaus's decision brought widespread criticism from a number of politicians and likely resulted in the slight reduction in the confidence that Czechs had in the presidency that month. After Klaus had granted amnesty to more than 6,000 criminals and had cleared the records of about 20,000 more on January 1, 2013, his popularity plunged, as did Czechs' level of trust in the presidency. ${ }^{127}$ There were efforts to charge Klaus with treason, in part because of the amnesty, but a decision of the Constitutional Court upheld the amnesty. In February, just weeks before he left office, Klaus published a book about his views on events that had shaped Europe since 1989, and he reserved two chapters for what he long had decried as disastrous for Europe: the Maastricht Treaty and the Treaty of Lisbon. ${ }^{128}$

Beginning in 2011, Klaus saw the Czech citizens' confidence in him descend, and even though it leveled in 2012, it collapsed during his last six months in office. Meanwhile, the EI increased, peaking in the spring of 2012 before beginning an almost imperceptible drop prior to Klaus leaving the presidency. The counterintuitive trend in 2011 of divergence between confidence in the presidency and the EI may have been the result of the respondents' slowness in shifting their views. It is more likely, however, that Czech Euroskepticism moved in opposition to Klaus's weakening credibility because Czechs perceived the EU as not acting vigorously enough to mitigate the continuing negative impact that the world economic crisis had on the Czech Republic, where the GDP declined and the deficit rose beginning in 2009, and on the rest of the EU. Another possibility is that Klaus's anti-EU messages still had traction, despite his political difficulties. From 2012 until Klaus's departure from the Hrad in March 2013, both the EI and the ESI showed slightly downward trends, perhaps due both to improvements in the world economic situation and the persistent weakening confidence in Klaus.

\section{- 36 -}

The Carl Beck Papers in Russian and East European Studies http://carlbeckpapers.pitt.edu | DOI 10.5195/cbp.2017.219 | Number 2503 


\section{Conclusion}

A large number of variables, stemming from internal political developments, economics, foreign affairs, ideology, and many other inputs, contributed to the emergence and growth of Euroskepticism in the Czech Republic. Identifying most of them may be possible, but it is far more difficult and perhaps impossible to calculate their precise impact or even weigh their relative importance. The purpose of this study, therefore, is limited to establishing Klaus's Euroskepticism as just one of the factors that shaped Czech public opinion and to suggesting the extent of his influence. This study's simple statistical analysis found a correlation between Euroskepticism and confidence in the presidency during the years Klaus held that office. Its examination of Klaus's speeches and writings demonstrated his frequent and highly structured criticisms of the EU. It presented Klaus's standpoint regarding the EU as an important element in shaping the distrust and negativism of Czechs toward the EU and their belief that the EU is on the wrong path.

Both confidence in the presidency and the EI, a measure based on three responses to the SE surveys, were closely related in the Czech Republic for more than half of Klaus's two five-year terms as presidentspecifically, the seven-year period from 2004 through 2010. During that time, the EI and Klaus's confidence ran parallel in 2005, and from the spring of 2007 through 2010, the relationship grew ever stronger, with the exception of the periods between the spring and autumn of 2008 and the spring and autumn of 2010. There was a decline of confidence in Klaus that lasted from the spring of 2011 until his departure from office, aside from 2012, when confidence in the presidency and the EI were nearly parallel. A possible explanation for why the EI increased, beginning in 2011, as confidence in Klaus started to ebb, is that Klaus's arguments against the EU continued to resonate with Czechs, even though they disagreed with his other positions. While he was president, Klaus's frequent, forceful, and highly specific criticisms of the EU were extremely effective. This may explain why, after Klaus left office and after the spotlight of the media no longer shone on him, the EI fell steadily, from 48.3 points in the spring of 2013, when Klaus still was president, to 31.0 in the spring of 2015, a drop of 17.3 points. In the autumn of 2015, the EI jumped to 48.7, certainly a response to the Eastern

Mediterranean migration crisis that shook the EU that year. Even then, it still was lower than the EI of 50 in the spring of 2012 (see Table 8). ${ }^{129}$

While this study, with its limited length, did not offer a complete analysis of Czech Euroskepticism, it considered two obvious alternative influences that strengthened Euroskepticism, neither of which seem to have exerted the same sort of impact on the public's perception of the EU as Klaus's constant harangues. Economic performance helps drive opinions about institutions and politicians. Therefore, one might expect the relationship between Eurostat's ESI and confidence in Klaus from 2004 to 2013 to be strong: the correlation is 0.59. ${ }^{130}$ There were two exceptions. In the second half of 2008 and the first half of 2009, when the global recession began, confidence in Klaus improved and the ESI worsened; then, in the second half of 2009, as the ESI started to improve, confidence in Klaus dropped. Most likely, Klaus was somewhat insulated from the wrath of the population, at least for a while, precisely because of his criticism of the EU and the euro and because of his warnings of economic difficulties, stemming from an overregulated market. (Ironically, it was the lack of regulation that contributed to the Great Recession.) The second anomaly was the last six months of Klaus's tenure as president, when the ESI increased slightly and confidence in the presidency decreased significantly. Meanwhile, from 2004 to 2013, the time when Klaus was president, the overall correlation between the ESI and EI (-0.63) approximates the correlation between confidence in Klaus and the EI (-0.68). ${ }^{131}$ For the period of spring 2007 through 2010, however, the correlation between the ESI and the EI (-0.52) is weaker than the correlation between confidence in Klaus and the EI (0.47). ${ }^{132}$ In short, the link between the ESI and confidence in Klaus was not as strong as the tie between the EI and confidence in the presidency, especially between the spring of 2007 and the autumn of 2010. The evidence suggests that Klaus's actions were more important than economics in forming the Czechs' anti-EU opinions. 
Klaus established and led the ODS before becoming president, and the ODS tended to do well in the various elections throughout Klaus's presidency, aside from the 2010 Senate elections and the 2012 Senate and regional elections. More research about the relationship between the ODS and Klaus during his presidency is desirable, but a casual examination of the EI during election cycles does not suggest any link between the ODS's victories and an increase in the EI. In fact, as the ODS began to face electoral difficulties, the EI jumped dramatically, and the opposite should occur if public opinion about the EU was dependent on the stance of the ODS. The electoral fate of the ODS also did not seem to have much of an effect on Klaus's confidence ratings. That could be because Klaus had resigned as leader of the ODS after its 2002 electoral defeats. He became the party's honorary chair, but as president, he was to maintain neutrality in politics, and in 2008, he resigned his honorary post. Klaus also avoided mentioning the ODS openly during his speeches as president. ${ }^{133}$ His separation from the ODS was so complete that, shortly before the October 2013 legislative election, Klaus told voters not to support the party. The traditional parties did poorly, among them the ODS, which came in fifth.

Other intervening variables nurtured Czech Euroskepticism, some that are difficult to measure. Czech and Euroskepticism ran parallel for much of the time that Klaus held the presidency. In particular, the lack of trust in the EU (Figure 1), a negative image of the EU (Figure 2), and a negative opinion about the direction of the EU (Figure 3), especially beginning in 2007, were remarkably close. After their experience as part of the Soviet Bloc, the Czechs distrusted foreign authorites and supranational structures, and many Czechs were suspicious that the EU was yet another multinational gargantuan seeking to dominate them by undermining their country's sovereignty. That fear provided fodder for Klaus, whose views often intersected with prevalent concerns among Czechs about the EU. The notion that the EU is overly bureaucratic and has too many regulations is common throughout the EU, as it is with many Czechs. Klaus was savvy enough to exploit those popular beliefs. The Czechs also did not see the EU as helping to stem the level of corruption in the Czech Republic. In the economic realm, EU membership had not spurred rapid growth in the Czech economy, and for some, the worldwide economic crisis and its slow recovery also bolstered Euroskepticism. ${ }^{134}$ Finally, Klaus was not the sole Euroskeptic public figure in the Czech Republic, and others played a role in raising popular doubts about the EU.

Klaus swayed public opinion about the EU because of his position as the country's president but also because his criticisms of the EU were steady, assertive, and focused on several specific points. It appears that, shortly after Klaus became president, his ongoing assault against the EU persuaded Czech voters to become wary of further EU integration and the institutions of the EU as a whole. Klaus criticized the draft EU constitution, the Treaty of Lisbon, the EU structure in Brussels, and the euro as components of the left-wing agenda of the Europeists, the label he applied to those who advanced integration at the expense of independent states. These Europeists, according to Klaus, also had a vested interest in increasing the democratic deficit, in order to augment the power of the nonelected EU bureaucrats. As an alternative, Klaus advocated a return to the principles of the free movement of goods, capital, and people that had been among the pillars of the European Economic Community, long before Delors and Maastricht. According to his plan, further integration was to evolve naturally, not through the promotion of a political agenda.

An important implication of this research is that, in the Czech Republic, whose political culture reserves a high status for its head of state, especially if that individual is well-educated, articulate, and courageous, the president has a great deal of influence over public opinion and can use the office as a bully pulpit. This study also suggests that there may be limits to the president's influence. If the president attempts to become an expert in too many fields and defies conventional knowledge, as Klaus did with global warming beginning in 2007, the president ultimately may lose credibility with the voters. Another difficulty may occur if the president opposes representative institutions, especially when their members support popular or relatively popular standpoints, as when Klaus opposed the Treaty of Lisbon and the ESM. Widely unpopular actions, like the broad amnesty Klaus issued when he was about to leave office or his homophobia, also can destroy a president's reputation and 
cause some citizens, who may have been under the president's influence regarding an unrelated issue, to abandon their position. ${ }^{135}$ These factors may explain the surge in positive opinions about the EU as Klaus approached the end of his second term. If this study is correct in identifying the Czech presidency's bully pulpit as a contributing factor in the rise of Euroskepticism in the Czech Republic, then it might be true that Zeman, the new president who expressed favorable opinions about the EU, may have had some influence in undoing the effects of Klaus. ${ }^{136}$ This may account, in part, for the slump in the EI after Klaus's departure as president.

The EI index, already on the decline as Klaus left office, continued to sink from the spring of 2013 until the spring of 2015, the first two years Klaus was out of office. From 48.3 in the first half of 2013, it dropped to 47.0 in the second half of the year. In 2014, it decreased to 41.7 in the first half of the year and then to 33.3 in the second half of the year. ${ }^{137}$ In the spring of 2015, it sank to 31.0. ${ }^{138}$ There was a falling-off in all three components, but the descent was somewhat steeper in the category of whether Czechs believed that the EU was headed in the right direction. It is foolish to think that the more favorable opinion of the EU among Czechs is only the result of Klaus's departure from the political scene. Much occurred between 2013 and 2015 to bolster unity in and support for the EU among Czechs. On the one hand, there were the positive experiences, like the entry of Croatia into the EU, elections to the European Parliament, the admission of Latvia and Lithuania into the eurozone, and even the 2014 landing of the European Space Agency probe Rosetta on Comet 67/P. On the other hand, there were dilemmas, including the threat of terrorism, the advance of the Islamic State of Iraq and the Levant (ISIL), the revolution in Ukraine, the tension over Russia's annexation of Crimea, the conflict in Ukraine with separatists, the murders at Charlie Hebdo, and the agony over the nagging sovereign debt crisis in Greece, all of which may have contributed to a belief in a greater need for solidarity among member states. The presence of so many variables makes it difficult to determine the true impact of Klaus's political retirement on the change in the perceptions of Czechs about the EU, and there is no public opinion poll for the period after Klaus left office to help gauge Czechs' perceptions of their former president. Nevertheless, it is highly likely that, since leaving office, Klaus's ability to shape Czech public opinion regarding the EU, through his continued barrage against the EU and his acerbic criticism of European integration, has weakened. ${ }^{139}$ The loss of the Czech presidential bully pulpit and intense media coverage appears to have diminished the impact of Klaus's Euroskeptic message.

Klaus, unfettered by the decorum of presidential office and the constraints of statesmanship after March 7, 2013, became far more radical in his Euroskepticism. As the research was underway for the autumn 2013 ES opinion poll, Klaus announced, in a new book he coauthored with members of his Václav Klaus Institute, that the Czech Republic should withdraw from the EU, a position which firmly places him in the hard Euroskeptic camp. ${ }^{140}$ His proposal came as no surprise, especially after he had made so many disparaging comments about the EU, including his remark, in February 2012, that "at the end of a dead-end road, there only exists the way back." "141 After he had left office, Klaus had less access to the Czech public than he once had enjoyed, and Zeman capitalized on Klaus's vulnerability. Commenting on Klaus's book, Zeman stated, "I hope that even Václav Klaus recognizes that there exists a phenomenon called European culture." 142

The British referendum on leaving the EU, which took place on June 23, 2016, afforded Klaus another opportunity to advance his views about European integration. A few days before the Brexit vote, as Klaus celebrated his seventy-fifth birthday, he told a Czech News Agency interviewer that the British should withdraw from the EU. Simultaneously, he called for the creation of a new political coalition in the European Parliament, Alternatives for Europe, to unite parties struggling against Europism. ${ }^{143}$ The proposed name is based on the German Euroskeptic and right-wing party Alternative für Deutschland (AfD). A day after the vote, when it was clear that the decision to leave the EU had won by a narrow margin, Klaus granted an interview to Czech Broadcasting's Radiožurnál, during which he barely contained his exuberance. "I wanted to stress that today is a wonderful day, a special day because what happened yesterday in the UK is a huge victory for all European democrats and for all people who want to live in a free world and who are totally dissatisfied with the way the 
European Union is going." Klaus deemed the Brexit victory equal in importance to the 2005 scuttling of the European constitution. Britain was "the cradle of democracy [and] the cradle of capitalism" that saved Europe twice in the last two centuries, "first from Napoleon and second from Hitler," and now it saved Europe from the "monster" that is the "Brussels elite." He reiterated that the EU is on a misguided path (bludná cesta) and has gone down "a blind alley" that it should not have taken. The EU was now weak and unable to get any weaker, affording Europeans the opportunity to reshape it, along the principles of reasonable cooperation, without overregulation. ${ }^{144}$

In November 2014, Sobotka, after having become prime minister ten months earlier, weighed Klaus's legacy of negativity regarding the EU. He maintained that Czech Euroskepticism "is the heritage of a Euroskeptic government, it is the heritage of the ardent Euroskeptic President Václav Klaus, who was president of the Czech republic for ten years, and that is a very long time. And during these ten years, he had a great potential to influence public opinion." ${ }^{145}$ Sobotka has a different viewpoint from the political scientists Amelia Hadfield and Silviu Piros, who posited that:

Klaus's own flavor of Euroscepticism has never truly taken hold, either abroad, or at home. His attempts to construct the image of a Eurosceptic Czech Republic have failed to take root both in the Brussels sphere (the Czech Republic is rarely if ever associated with the "classic" Eurosceptics like UK or Denmark), or domestically (Eurobarometer results indicate that the Czech public still favors its membership of the EU and general trust in the EU institutions, even exceeding trust in national institutions). As some observers have suggested, Václav Klaus may operate merely on the basis of the attention gained from being a colourful Eurosceptic, rather than exemplifying the skill and subtlety needed to affect genuine limitations upon aspects of the EU, and indeed to garner the necessary political and public support for such attitudes to prevail. Accordingly, his Eurosceptic actions have had a limited impact on his country's reputation and have not fundamentally weakened its ties with its European colleagues, or the international community. ${ }^{146}$

This study takes exception to at least part of Hadfield and Piros's argument and lends support to Sobotka's interpretation that Klaus, during his decade in the presidency, contributed much to the increase of Euroskepticism among Czechs, even though Klaus never motivated the Czechs to reject further European integration or to go down the path of withdrawing from the EU. 


\section{ENDNOTES}

In November 2013, I completed the initial research for this paper and presented it as "Václav Klaus and Czech Opinion about the European Union" at the Association for Slavic, East European, and Eurasian Studies Conference in Boston, MA. I am indebted to Jennifer Emery, formerly a member of the Department of Government at the University of West Florida and now with the Washington Center, in Washington, DC, for assisting me in preparing the Euroskepticism Index. Philip J. Howe, a political scientist at Adrian College (Adrian, MI), provided invaluable insight into some of the statistical aspects of this study. Lenka Kocková managed to acquire some sources when I was not in the Czech Republic, and she checked the manuscript for errors in Czech. Vojtěch Kocek scurried to used book stores in Prague to retrieve a few volumes of Klaus's writings missing from my personal library, and Alex Švamberk, a journalist with Novinky.cz, acquired the photographs. Robin A. Remington (Universiy of Missouri-Columbia, emeritus, and Peace Haven International, Columbia, MO) encouraged me to undertake this study. Stanislav Perkner (Humphreys College, Stockton, CA), Robert K. Evanson (University of Missouri at Kansas City, emeritus), and Brian Williams (University of West Florida, in Pensacola, FL) were kind enough to comment on the manuscript before I submitted it for publication. The comments of the two anonymous readers of the manuscript, along with those of Bob Donnorummo, who is one of the editors of the Carl Beck Papers, also served as valuable feedback for improving this study. Judy Hale Young (University of West Florida) proofread the text. I also wish to thank TMN and several individuals at my institution for their assistance and valued support. As always, I appreciate the love and understanding of my four children, Thomas and Karl, along with their families, as well as Martin and Klára. Since the latter two still are at home, they must tolerate my academic work and frequent musings about my endeavors.

1. Eurobarometer, "Public Opinion in the European Union,” (POEU), Standard Eurobarometer (SE) 62, “Annexes/Anhänge," ([Brussels]: European Commission, Public Opinion Analysis Sector, November-December 2004), question 10.13. The three SE survey questions that apply to this research appear in Table 4 of this study. The website for all the Eurobarometer reports is http://ec.europa.eu/COMMFrontOffice/PublicOpinion/index.cfm/Survey/index\#p=1\&instruments=STANDARD. SE surveys generally rely on responses from about 1,000 individuals, and their confidence limits are as follows:

\begin{tabular}{|l|c|c|c|c|c|}
\hline Observed Percentages & $10 \%$ or $90 \%$ & $20 \%$ or $80 \%$ & $30 \%$ or $70 \%$ & $40 \%$ or $60 \%$ & $50 \%$ \\
\hline Confidence Limits & \pm 1.9 points & \pm 2.5 points & \pm 2.7 points & \pm 3.0 points & \pm 3.1 points \\
\hline
\end{tabular}

The above information appears in the "Technical Specifications" of the various reports. See, for example, Eurobarometer, POEU, SE 73, November 2010, p. 214, http://ec.europa.eu/public_opinion/archives/eb/eb73/eb73_vol2_en.pdf.

2. Eurobarometer, POEU, “Annexes/Anhänge,” SE 62, November-December 2004, question 13.

3. Eurobarometer, "The European Citizens and the Future of Europe: Qualitative Study in the 25 Member States, Qualitative StudyOptem" ([Brussels]: European Commission, Directorate-General Communication, May 2006, field work February-March 2006), 9, http://ec.europa.eu/public_opinion/archives/quali/ql_futur_en.pdf.

4. Eurobarometer, POEU, “Final Report,” SE 65, January 2007, pp. 9-31, http://ec.europa.eu/public_opinion/archives/eb/eb65/ eb65_en.pdf.

5. Eurostat, "GDP per Capita in PPS," at

http://ec.europa.eu/eurostat/tgm/table.do?tab=table\&init=1\&language=en\&pcode=tec00114\&plugin=1.

6. Eurostat, "Real GDP Growth Rate-Volume," at http://epp.eurostat.ec.europa.eu/tgm/table.do?tab=table \&plugin=1\&language= en\&pcode=tec00115; and World Bank, "GDP Growth (annual\%)” at http://data.worldbank.org/indicator/NY.GDP.MKTP.KD.ZG/ countries/CZ?display=default. 
7. Eurobarometer, POEU, “Tables of Results," SE 79, spring 2013, question A26. The question was "Would you say that you are very optimistic, fairly optimistic, fairly pessimistic or very pessimistic about the future of the EU?" This question debuted in 2012/77 and was not useful for measuring any long-term trends in this study. The EU member states facing economic crises at the time of the survey were Cyprus, Greece, Ireland, Italy, Portugal, Slovenia, and Spain.

8. It is possible that the economic crisis had a negative effect on the Germans, many of whom felt they had to shore up less productive EU economies. Otherwise, the countries that faced economic crises had high rates of distrust of the EU, even though the EU was poised to support them financially: Cyprus ( 83 percent), Greece ( 80 percent), Spain (75 percent), Portugal (71 percent), Slovenia (63 percent), along with Italy and Ireland (61 percent). Eurobarometer, POEU, "Tables of Results," SE 79/2013, question A12.4. For the long-term trends, see Figure 1 and the data in Table 5 of this study. The question regarding trust in the EU is in Table 4.

9. As with the measurement of optimism about the EU's future and trust in the EU, the image of the EU among citizens of member states facing economic crises was negative: Cyprus (59 percent), Greece (50 percent), Portugal (42 percent), and Spain (38 percent). Ironically, more Irish had a positive ( 36 percent) than negative ( 20 percent) opinion of the EU, and the same was true with the Slovenes (31 percent positive, as opposed to 26 percent negative). Eurobarometer, POEU, "Tables of Results," SE 79/2013, question A13. For the question, see Table 4 of this study. The long-term trends for negative image are in Figure 2, the negative opinions about the direction of the EU are in Figure 3, and the data for the Czech Republic and EU is in Table 6.

10. Eurobarometer, POEU, “Tables of Results,” SE 79, spring 2013, question A26.

11. A humorous example is a 2010 article that lists the number of words certain documents contain in Czech: "Pythagorean Theorem, with 24 words; Lord's Prayer, 66 words; Archimedes' principle, 67; Ten Commandments, 179; American Declaration of Independence, 1,300; American Constitution and its amendments, 7,818; EU decree on the sale of cabbage, 26,911." Luděk Frýbort, "O tom bruselském zelí aneb Od majzlíku k počítači a zase zpátky,” Neviditelný pes, April 15, 2013, http://neviditelnypes.lidovky.cz/ spolecnost-o-tom-bruselskem-zeli-dqn-/p_spolecnost.aspx?c=A130413_165906_p_spolecnost_wag.

12. Far more systematic accounts of Euroskepticism in the Czech Republic exist, including Zdenka Mansfeldová and Guasti Petra, eds., Euroskepticismus a percepce evropského integračního procesu v České republice v letech 2004-2010 (Prague: Sociologický ústav AVČR, 2013); Søren Riishøj, "Europeanization and Euroskepticism: Experiences from Poland and the Czech Republic," Political Science Publications 25/2010 (Odense, Denmark: University of Southern Denmark, 2010), http://static.sdu.dk/mediafiles// C/1/7/\%7BC1706F42-D5DC-47A0-9CA9-8708ABF499F9\%7DEuroscepticism_hjemmeside.pdf; Vlastimil Havlík, České politické strany a evropská integrace: Evropeizace, evropanství, euroskepticismus? (Brno: Nakladatelství Mezinárodní politologický ústav Masarykovy univerzity, 2010); and Vlastimil Havlík and Petr Kaniok, eds., Euroskepticismus a země střední a východní Evropy (Brno: Masarykova univerzita, Mezinárodní politologický ústav, 2006). For an account of the Czech Republic's relations with the EU from the time of negotiations for membership through the Czech Republic's presidency of the EU that ended in June 2009, see Dan Marek and Michael Baun, The Czech Republic and the European Union (Abingdon and New York: Routledge, 2011). The first two chapters include references to Klaus's opinions and actions with respect to the EU, particularly before May 2004. For an analysis of Euroskepticism among Czech parliamentarians between 2000 and 2004, based on anonymous interviews, see Markéta Rulíková, Euroscepticism in EU Candidate Countries: Variability in Political Elite Resistance to EU Accession in the Czech Republic and Slovakia (Saarbrücken, Germany: VDM Verlag Dr. Müller, 2010), esp. "Attitudes of the Czech and Slovak Political Elite towards the Integration Process in Europe," 118-205.

13. Klaus's presidency ended because of a two-term limit. Among the books about Klaus are those of two academics: Lubomír Kopeček, Fenomén Václav Klaus: Politická biografie (Brno: Barrister \& Principal, 2012); and Jiř́ Pehe, Klaus: Portrét politika ve dvaceti obrazech (Prostor nakladatelství, s.r.o., 2010). See also David Klimeš, Václav Klaus: Deset let na Pražském hradě (Prague: Mladá fronta, a.s., 2013); Consummate Contrarian: A Collection of Articles and Essays on Divisive Czech Leader Václav Klaus, Intro. by Jiří Pehe, Transitions Online Series, vol. 2 (Prague: Transitions Online, 2013).

14. The American president, Theodore Roosevelt, Jr. (1858-1919) coined the term bully pulpit to imply the powerful platform his office provided him for shaping public opinion. Americans continue to use the term. 
15. In 2006, Klaus noted that, after having reviewed his statements about the EU from 1995, he realized he had not changed his opinions. Václav Klaus, interview for Mladá fronta Dnes, February 25, 2005, in Václav Klaus, Rok čtvrtý, 2006: Projevy, články, eseje (Prague: Euromedia Group k.s.-Knižní klub, 2007), 415. Klaus published several works, many of which include collections of his writings and speeches, before and after becoming president. Even in the early works, elements of Euroskepticism emerge, such as his January 1995 speech to the Parliamentary Assembly of the Council of Europe, in which he questioned the tempo and character of European integration. See Klaus's "Evropa, naše viza a naše strategie (projev před parlamentním shromážděním Rady Evropy)," in Václav Klaus, Dopočítáváni do jedné, illustrations by Vladimír Renčín, Epilogue by Václav Bělohradský (Prague: Management Press, Ringier ČR, 1995), 141-145. The book's illustrator, Vladimír Renčín (1941-2017) is a popular cartoonist and humorist who often tackled political topics. Certainly, Klaus was aware that Renčín's art would make his book more appealing to readers. This study does not attempt to provide a complete explanation of Klaus's position toward the EU, either before or during his presidency, although components of it will appear throughout the work.

16. Václav Klaus, “Z vystoupení v Nedělní partii na TV Prima,” Nedělní partie, TV Prima, February 17, 2008, in Klaus, Rok šestý, 2008: Projevy, články, eseje (Prague: Euromedia Group k.s.-Knižní klub, 2009), 360. Several studies pertaining to Klaus’s Euroskepticism exist, including Vít Hloušek and Petr Kaniok, "Strategic or Identity-based Euroscepticism? The Euro Discourse of Václav Klaus," Romanian Journal of Political Science 14, no. 1 (Summer 2014): 35-60; and Petr Kaniok and Vít Hloušek, "Shaping the Czech Debate on the Euro: Position of Václav Klaus in the 1999-2002 Period," Romanian Journal of European Affairs 14 , no. 2 (June 2014): 42-62.

17. Aleks Szczerbiak and Paul A. Taggart, "Introduction," in Aleks Szczerbiak and Paul A. Taggart, eds., Opposing Europe?: The Comparative Party Politics of Euroscepticism, vol. 1: Case Studies and Country Surveys (Oxford and New York: Oxford University Press, 2008), 7-10.

18. Hloušek and Kaniok, "Strategic or Identity-based Euroscepticism?," 53-54; and Kaniok and Hloušek, "Shaping the Czech Debate on the Euro," 55-57. In their articles, Hloušek and Kaniok explained the features of hard and soft Euroskepticism that Szczerbiak and Taggart had identified.

19. Vlastimil Havlík, “Česká republika,” in Vlastimil Havlík and Petr Kaniok, ed, Euroskepticismus a země střední a východní Evropy, Ediční řada studie, vol. 41 (Brno: Masarykova univerzita, Mezinárodní politologický ústav, 2006), 66-67.

20. An excellent summary of Klaus's opinions about the EU when he served as prime minister appear in Peter Bugge, Czech Perceptions of the Perspective of EU Membership: Havel vs. Klaus, EU Working Paper RSC No. 2000/10 (San Domenico di Fiesole: European University Institute, Robert Schuman Centre for Advanced Studies, 2000), esp. 23-38.

21. Petr Pithart, "The Czech Republic on the Road to the European Union-A Contribution to Common Democratic Values," September 25, 2002, at Peter Pithart, senátor za volební obvod č. 44 Chrudim, http://www.pithart.cz/archiv_textu_tisk.pp?id=175.

22. Václav Klaus, Evropa pohledem politika, pohledem ekonoma (Prague: Centrum pro ekonomiku a politiku, 2001). This book contains the basic viewpoints of Klaus regarding the EU and the euro. He often repeated them as president, and they will appear later in this study.

23. Václav Klaus, "Informace v Poslanecké sněmovně o vystoupení v Evropském parlamentu,” December 7, 2012, in Klaus v Bruselu (Prague: Centrum pro ekonomiku a politiku, 2001). 21-22. The Maastricht Treaty of 1992 transformed the European Community into the European Union and paved the way for a single currency.

24. Václav Klaus and Petr Hájek, Narovinu: Hovory V. K. s Petrem Hájkem nejen o tom, co bylo, je a bude (Prague: Rabbit and Rabbit, 2001), 70 (quotations) and 311.

25. Klaus and Hájek, Narovinu, 311.

26. The Czech Parliament elected the president from 1993 until January 2013, which is when the first popular election for the president took place. 
27. Václav Klaus, "Notes for the London Speech: New Europe Seminar on the Future of the European Union, January 10, 2001, Chatham House, London," in Klaus, Evropa pohledem politika, 219. Klaus's remarks contained many of the points he continued to make in the future.

28. CVVM, Sociologický ústav AV ČR, v.v.i., "Hodnocení působení Václava Klause v prezidentském úřadě,” April 15, 2013 (note the incorrect year of 2012 on the publication date), Graph 2, http://cvvm.soc.cas.cz/. The questions for the survey appear in Table 4 of this chapter. Details regarding the margin of error do not generally appear with CVVM polls, but their samples typically involve slightly more than 1,000 individuals, and the tables often include a statement that changes of \pm 3 percent are not statistically significant. CVVM is an objective and highly respected polling organization, and its surveys of the popularity of politicians, including the presidents, are key sources of data for the media and analysts.

29. CVVM, "Důvěra vybraným politikům," March 5, 2013, Table 1, http://cvvm.soc.cas.cz/. The questions for the survey appear in Table 4 of this study.

30. For Klaus's popularity, see Table 1. Zeman's popularity, see CVVM, Sociologický ústav AV ČR, v.v.i., "Důvěra vybraným politikům," April 9, 2014, and June 3, 2015, Table 1, in each case, http://cvvm.soc.cas.cz/. Zeman's results were 51 (March 2013), 48 (September 2013), 47 (March 2014), 49 (September 2014), 40 (January 2015), and 41 (May 2015).

31. SEs, conducted biannually, are more desirable than the polls from CVVM, which gauged the opinions of Czech citizens about faith in the EU, satisfaction with membership in the EU, and European integration. CVVM often conducted its surveys only once each year, and they offer no direct comparison with the rest of the EU.

32. In autumn 2006, Eurobarometer first asked respondents about the direction in which the EU was headed, but it did not appear in spring 2007. See Tables 4 and 7 as well as Figure 3.

33. The correlation coefficient measures the degree of relationship between two variables. A positive number means that the movement of two variables is parallel, while a negative number indicates that the two variables are moving in opposite directions. In this case, the r-squared is 0.47 and the $p$-value is 0.00124 (significant at $p<0.05$ ).

34. The $\mathrm{r}$-squared is 0.053478 , and the $\mathrm{p}$-value is 0.426449 (not significant at $\mathrm{p}<0.05$ ).

35. Once again, the reliability of the statistics decreases as the number of pairs diminishes.

Correlation between Confidence in Klaus and the EI between 2007 and 2010

\begin{tabular}{|l|c|r|r|r|c|}
\hline \multirow{2}{*}{ Time Period } & \multirow{2}{*}{$\begin{array}{c}\text { Data Pairs } \\
\text { (Observations) }\end{array}$} & \multirow{2}{*}{ Correlation } & \multirow{2}{*}{ R-squared } & \multicolumn{2}{|c|}{ P-value Calculation } \\
\cline { 5 - 6 } & & & & \multicolumn{1}{|c|}{ P-value } & Significant at $\mathbf{p}<\mathbf{0 . 5}$ \\
\hline $\mathbf{2 0 0 7 / 1 - 2 0 1 0 / 2}$ & 8 & 0.472017 & 0.222800 & 0.237658 & Not Significant \\
\hline $\mathbf{2 0 0 7 / 2 - 2 0 1 0 / 2}$ & 7 & 0.752976 & 0.566972 & 0.050767 & Not Significant \\
\hline $\mathbf{2 0 0 8 / 1 - 2 0 1 0 / 2}$ & 6 & 0.881677 & 0.777355 & 0.020198 & Significant \\
\hline $\mathbf{2 0 0 8 / 2 - 2 0 1 0 / 2}$ & 5 & 0.865815 & 0.749635 & 0.057812 & Not Significant \\
\hline $\mathbf{2 0 0 9 / 1 - 2 0 1 0 / 2}$ & 4 & 0.948197 & 0.899077 & 0.051900 & Not Significant \\
\hline $\mathbf{2 0 0 9 / 2 - 2 0 1 0 / 2}$ & 3 & 0.949321 & 0.901210 & 0.203588 & Not Significant \\
\hline $\mathbf{2 0 1 0} / \mathbf{1 - 2 0 1 0} / \mathbf{2}$ & 2 & -1.000000 & 1.000000 & N/A & N/A \\
\hline $\mathbf{2 0 1 0 / 2}$ & 1 & N/A & N/A & N/A & N/A \\
\hline
\end{tabular}


36. The first volume of Klaus's speeches, articles, and other writings is Václav Klaus, in Rok první, 2003: Projevy, články, eseje (Prague: Euromedia Group k.s.-Knižní klub, 2004). The other volumes have the same subtitle and publisher: Rok druhý, 2004 (published in 2005); Rok třetí, 2005 (2006); Rok čtvrtý, 2006 (2007); Rok pátý, 2007 (2008); Rok šestý, 2008 (2009); Rok sedmý, 2009 (2010); Rok osmý, 2010 (2011); Rok devatý, 2011 (2012); and Rok desátý, 2012 (2013). The number of articles, speeches, and other statements, excluding vetoes of legislation, in Klaus's collected works that include a reference to the EU or the euro in the title is as follows: 2003 (3), 2004 (10), 2005 (26), 2006 (11, including two entries in the "Interview" section), 2007 (7), 2008 (6), 2009 (19), 2010 (13), 2011 (17), and 2012 (13). The yearly issues of Klaus's works, while thorough, are not complete. Nevertheless, they provide a means of gauging the number of times each year he wrote and spoke about the EU and the euro, especially in Czech. Several of Klaus's writings and speeches from 2004 and before appear in English in Václav Klaus, On the Road to Democracy: The Czech Republic from Communism to Free Society, ed. John C. Goodman, foreword by Gary S. Becker (Dallas, TX: National Center for Policy Analysis, 2005).

37. Otto Eibl, Miloš Gregor, and Alena Macková, “O čem a jak hovořil Václav Klaus ve svých veřejných projevech,” Politologický časopis/Czech Journal of Political Science (4/2013): 392-418. On the numbers of speeches, see 498 and 416 , note 14. Klaus's website, http://www.klaus.cz/, duplicates a great deal of the material contained in the yearly volumes of his collected speeches and other works that he published while serving as president. Eibl, Gregor, and Macková did not provide their raw data. Had they done so, it would have been possible to construct a study that correlates Klaus's speeches and writings regarding the EU with the EI.

38. Eibl, Gregor, and Macková, “O čem a jak hovořil Václav Klaus,” 399-400. I calculated the percentages from the table on p. 400.

39. Eibl, Gregor, and Macková, “O čem a jak hovořil Václav Klaus,” 402-404 and 414.

40. Eibl, Gregor, and Macková, “O čem a jak hovořil Václav Klaus,” 411.

41. Václav Klaus, "Pár slov o některých mých prezidentských aktivitách,” Deníky Bohemia, May 14, 2003, in Václav Klaus and Jeroným Janíček, Přerušený rozhovor: Václav Klaus v diskusi s Jeronýmem Janíčkem (Prague: Academia, nakladatelství Akademie věd České republiky, 2003), 142. Klaus repeated that joining the EU was a marriage of convenience in "Zbytečné hrátky kolem referenda," Mladá fronta Dnes, May 18, 2003, in Klaus, Rok první, 137-138, quotation on 137.

42. Delors, a former French Socialist and three-time president of the European Commission, was instrumental in the 1993 inauguration of the EU's single market. On Klaus's efforts to derail the draft EU constitution, see Kopeček, Fenomén, $167-169$.

43. Václav Klaus, "Evropská ústava změní naši budoucnost,” Mladá fronta Dnes, September 18, 2003, in Klaus, Rok první, 143-145, quotation on 144 .

44. Václav Klaus, "Rozhovor prezidenta Václava Klause pro BBC World-HardTalk,” November 14, 2003, http://www.klaus.cz/ clanky/1026. He first used the comparison during a March 1993 speech, when he received the Great Honor Plate of the Peutinger Collegium (Der Große Ehrenteller des Peutinger-Collegiums). He remarked that, "Before the Czech Republic is one essential goal: be European while at the same time not dissolving in Europeanism like a sugar cube in a cup of coffee. And that is, in the end, a goal, even for other East European states." The Czech original is "před Českou republikou stojí jeden podstatný úkol: být evropskou, a přitom se v evropanství nerozpustit jako kostka cukru v šálku kávy. A to je ostatně úkol i pro ostatní státy východní Evropy.” "Změny v Praze a evropské souvislosti," in Václav Klaus, Česká cesta, illustrations by Vladimír Jiránek (Prague: PROFILE, s.r.o., 1994), Projev při udělení Peutingerovy ceny, March 22, 1993, 136. Česká cesta is an early collection of Klaus’s speeches and writings, and the final section, "Evropa a 'česká cesta,"” ("Europe and the 'Czech Path"') is useful for understanding Klaus's stance on European integration in 1993-1994, immediately after the division of Czechoslovakia, including his concept of Europeism and its Europeist proponents, terms that Klaus coined and used throughout his presidency. The illustrator of Česká cesta, Vladimír Jiránek (1938-2012), was a film director and cartoonist whose humorous drawings took on social and political issues.

45. Václav Klaus, “The Future of Euro: A View of a Concerned Outsider,” November 20, 2003, in Klaus, On the Road, 132-138, and at http://www.klaus.cz/clanky/439. The Czech version is "Euro a jeho budoucnost: Pohled z budoucí členské země. Projev

přednesený na konferenci Cato Institute,’ November 20, 2003 (mistakenly listed as January 19, 2004), in Klaus, Rok prvni, 186-194. Klaus gave the same speech in 2004 (see Klaus, Rok druhý, 245-253). It also appears in Klaus's Ekonomie a ekonomika: Texty z let 1996-2006 (Prague: Euromedia Group, k.s.-Knižní klub, 2006). 
46. Václav Klaus, “Smysl bruselské nedohody,” Mladá fronta Dnes, December 16, 2013, in Klaus, Rok první, 152 (second quotation) and 154 (first quotation).

47. Václav Klaus, "Evropské ekonomické problémy a jejich neřešení," Právo, January 31, 2004, in Klaus, Rok druhý, 186-190. An English version is Klaus, "European Economic Problems and Their Nonsolutions," in On the Road, 148-151.

48. Václav Klaus, “Kde je skutečná podstata sporu o Evropskou unii a její ústavu?” Lidové noviny, February 14, 2004, in Klaus, Rok druhý, 191-198, esp. 197.

49. Václav Klaus, "Euro a jeho budoucnost: Pohled z budoucí členské země," Centrum pro ekonomiku a politiku Newsletter (CEPu Newsletter), February 7, 2004, in Klaus, Rok druhý, 245-253. Klaus gave the same speech in 2003 (see Klaus, Rok první, 186-194). The Center for Economics and Politics is a conservative think tank that Klaus established in 1998, after his government had collapsed. Its website is at http://cepin.cz/cze/index.php.

50. Václav Klaus, “Dopis Vladimíru Špidlovi, předsedovi vlády ČR,” March 16, 2004, in Klaus, Rok druhý, 282-286.

51. Václav Klaus, “Neztrat’me se v Evropské unii!” Mladá fronta Dnes, April 22, 2004, in Klaus, Rok první, 207.

52. Václav Klaus, "Projev v předvečer vstupu České republiky do Evropské unie,” April 30, 2004, in Klaus, Rok druhý, 30. An English version is "Address of the President of the Czech Republic Delivered on the Eve of the Accession of the Czech Republic to the European Union," in Klaus, On the Road, 145-147.

53. Václav Klaus, Evropa Václava Klause (Prague: Euromedia Group k.s.-Knížní klub, 2004).

54. On April 2, 2013, shortly after becoming president and during the visit of José Manuel Barroso (born 1956), president of the European Commission, Zeman began flying the flag over the Prague Castle.

55. Václav Klaus, Právo, June 1, 2004, in Alexandr Kramer, Interview: 69 novinářských rozhovorů, vol. 4 (Brno: Nakladatelství DOPLNĚK, 2005), 329. On Klaus's Europeism, see also Kopeček, Fenomén, 170-172. Journalists from the Communist newspaper Rudé Právo established Právo in 1990 as an independent newspaper. It has a leftist, pro-Social Democratic stance, and it is the only major newspaper in the Czech Republic not under foreign ownership.

56. Václav Klaus, “Implikace nedávného rozšíření Evropské unie: Pokus o prvotní analýzu,” June 22, 2004, in Klaus Rok druhý, 99.

57. Václav Klaus, “Náš dnešní evropský problem,” August 29, 2004, in Klaus, Rok druhý, 101-106.

58. Václav Klaus, “Teze k setkání s velvyslanci České republiky,” September 1, 2004, in Klaus, Rok druhý, 107-108.

59. Václav Klaus, “Turecko, Evropa a Evropská unie,” Právo, September 30, 2004, in Klaus, Rok druhý, 230.

60. Václav Klaus, "European Problems and Their Non-Solutions," Bruges Group, October 25, 2004, http://www.brugesgroup.com/ news.live?article=250\&keyword=11. See also Klaus, "Evropské problémy a jejich neřešení," October 20, 2004, in Klaus, Rok druhý, 2004, 33-37.

61. Václav Klaus, as quoted in Hospodářské noviny, November 16, 2004, in Klaus, Rok druhý, 332.

62. Václav Klaus, “Integrace či unifikace Evropy,” CEPu Newsletter, December 2004, http://cepin.cz/docs/newslettery/2004-12.pdf.

63. Václav Klaus, "Projev na státní večeři při př́ležitosti návštěvy prezidenta Polské republiky Aleksandera Kwaśniewského," December 7, 2004, in Klaus, Rok druhý, 175.

64. Václav Klaus, Právo, December 11, 2004, in Kramer, Interview, vol. 4, 468.

65. Václav Klaus, "Novoroční projev,” January 1, 2005, in Klaus, Rok druhý, 55.

-46 -

The Carl Beck Papers in Russian and East European Studies

http://carlbeckpapers.pitt.edu | DOI 10.5195/cbp.2017.219 | Number 2503 
66. Jiří Pehe, “An Uneasy Journey,” The European, June 6, 2014, http://www.theeuropean-magazine.com/jiri-pehe--2/8564euroskepticism-in-the-czech-republic.

67. Václav Klaus, "Důležité je mít vizi," Fraser Forum, January 25, 2005, in Klaus, Rok třetí, 335. Klaus often invoked the marriage comparison. See also Václav Klaus, "The Czech Republic and the EU: A Marriage of Convenience, Not Love. Speech for the Commonwealth Club of California and the World Affairs Council of Northern California, San Francisco, November 8, 2004," in Klaus, On the Road, 152-155.

68. Václav Klaus, "Mám strach o Evropu,” Frankfurter Allgemeine Zeitung, March 15, 2005, in Klaus, Rok třetí, 79, 80 and 83.

69. Václav Klaus, “Předmluva k publikaci CEPu ‘Řekneme své ANO nebo NE evropské ústavě,’” April 2005, in Klaus, Rok třetí, 85 (quotation) and 89-90.

70. "Paroubek pohrozil Klausovi omezením zahraničních cest,” Novinky.cz, May 26, 2005, http://www.novinky.cz/domaci/57246paroubek-pohrozil-klausovi-omezenim-zahranicnich-cest.html.

71. Václav Klaus, “Využijme ‘období reflexe’ pro vymezení jiné Evropské unie,” Lidové noviny, July 16, 2015, in Klaus, Rok třetí, 139 (quotation) and 140-141.

72. On March 11, 2005, Klaus refused to name nearly three dozen candidates, whom the government had supported, for positions as judges because they were too young. Another difficulty was the number of accusations of financial impropriety about the Social Democratic prime minister, Stanislav Gross (1969-2015). In the first half of April, several members of his coalition attempted to resign and support the Social Democrats in a minority government, not through a coalition but an opposition agreement. Klaus refused the arrangement, stating that "I will not allow the development of such a government." As a result, on April 25 the government collapsed. The electorate's faith in the politicians fell, and these events had a negative effect on Klaus's popularity and confidence ratings in polls taken March 21-28 and April 18-25, as seen in Tables 7 and 8. Klaus's statement is in lkr, "Klaus odmítl vládu menšiny bez podpory," iDNES.cz, April 15, 2005, http://zpravy.idnes.cz/klaus-odmitl-vladu-mensiny-bez-podpory-d9u/domaci.aspx?c=A050415_124850_domaci_lkr.

73. The number of undecided respondents was 23 in February, 15 in April, and 25 in June. Apparently, some of those who had favored the draft EU constitution moved to the undecided camp. CVVM, "Smlouva o Ústavě pro Evropu očima veřejnosti," August 23, 2005, Table 5, http://cvvm.soc.cas.cz/media/com_form2content/documents/c1/a3234/f3/100506s_pm50823.pdf.

74. Christian Von Neef and Jan Puhl, "Wie zu Breschnews Zeiten,” Der Spiegel, March 13, 2006, http://www.spiegel.de/spiegel/ print/d-46237026.html.

75. Václav Klaus, “Co je to evropeismus?" Mladá fronta Dnes, April 8, 2006 in Klaus, Rok šestý, 152-167 (first quotation, 152; second, 157). An English version of Klaus's "What Is Europeism?" is at http://www.klaus.cz/clanky/1326. Although he did not use the term evropeismus, Klaus repeated the negative characteristics he associated with the term in an interview in 2014:

"multiculturalism, transnationalism, feminism and genderism, homosexuality, human-rightism, environmentalism." Jan Rovenský et al., Dvacet pět let poté: Klaus Pithart, Rychetský a Zeman v rozhovorech o společnosti a politice (Prague: Filosofia, 2014), 51. Klaus reviewed his objections to the EU on pp. 47-54.

76. Václav Klaus, “Nalejme si čistého vína ohledně evropské ústavy,” Mladá fronta Dnes, January 22, 2007, in Klaus, Rok pátý, 249251.

77. Václav Klaus, “Před debatou o euroústavě,” Hospodářské noviny, June 13, 2007, in Klaus, Rok pátý, 259-261.

78. Václav Klaus, “K everopské ústavní smlouvě,” Dziennik, January 26, 2007, and "K ústavní smlouvě a českým zájmům v Evropské unii," Hospodárské noviny, February 9, 2007, in Klaus, Rok pátý, 377-381.

79. Václav Klaus,“K deficitu svobody v Evropské unii,” Frankfurter Allgemeine Zeitung, June 20, 2007, in Klaus, Rok pátý, 389-392.

80. Václav Klaus,“K jednání Evropské rady v Bruselu,” TV Prima, June 24, 2007, in Klaus, Rok pátý, 392-395. 
81. Václav Klaus,“Ke směřování Evropské unie,” Rzeczpospolita, July 3, 2007, in Klaus, Rok pátý, 397 and 398 (for the "isms”).

82. The expanded version of Klaus's book is Modrá, nikoli zelená planeta. Co je ohroženo: klima, nebo svoboda? $2^{\text {nd }}$ ed. (Prague: Nakladatelství Dokořán, s.r.o., 2009). The English version is Blue Planet in Green Shackles. What Is Endangered: Climate or Freedom? Foreword by Fred L. Smith, Jr. (Washington, DC: Competitive Enterprise Institute, 2008).

83. Pavel Nováček, “Živá planeta: Sto omylů Václava Klause,” September 17, 2007, http://www.sustainable.cz/zivaplaneta.htm.

84. Václav Klaus, "Vystoupení za Euro Business Breakfast,” December 4, 2007, in Klaus, Rok pátý, 103-104.

85. An excellent source for images of the doomed library is Milena Ředinová and Zdeněk A. Tichý, eds., The Eye above Prague: A Library for the Third Millennium, Prefaces by V. Jehlička et al., trans. Kateřina Hilská (Prague: National Library of the Czech Republic, 2007).

86. The double-majority voting procedure is contained in the Lisbon Treaty and came into effect in 2014. It requires that decisions of the Council of the European Union have the support of a minimum of 55 percent of its members, who, in turn, must represent 65 percent or more of the EU's citizens. The requirement is an effort to diminish the democratic deficit.

87. Václav Klaus, “První kandidátský projev,” February 8, 2008, in Klaus, Rok šestý, 73.

88. On the election, see Pehe, Klaus, 245-259.

89. Václav Klaus, “Odpověd’ Ústavnímu soudu ohledně Lisabonské smlouvy,” June 3, 2008, in Klaus, Rok šestý, 307-318.

90. Klaus's explanations for these two vetoes are in "Zákon ze dne 24. dubna 2008 o rovném zacházení a o právních prostředcích ochrany před diskriminací a o změně některých zákonů (Antidiskriminační zákon)," May 16, 2008, and "Zákon ze dne 18 července 2008, kterým se mění zákon č. 356/2003 Sb., o chemických látkách a chemických př́pravcích a o změně některých zákonů ve znění pozdějších předpisů," August 11, 2008, in Klaus, Rok šestý, 345-350.

91. Václav Klaus, “Z rozhovoru pro týdeník Euro,” Euro, August 25, 2008, in Klaus, Rok šestý, 382.

92. Václav Klaus, “Rozhovor prezidenta republiky pro polský deník Rzeczpospolita,” October 13, 2008, http://www.klaus.cz/ clanky/1302. At the time, there were approximately 70 transnational euroregions.

93. Václav Klaus, Prezident republiky k Lisabonské smlouvě, ed. Martin Slaný (N.p.: Euromedia Group, k.s., 2009), 41 (first quotation) and 44 (second quotation). Klaus negotiated an opt-out provision with respect to the Charter of Fundamental Rights by promising to sign the Treaty of Lisbon if the Czech Republic received the opt-out and if the Constitutional Court decided that the Treaty of Lisbon was compatible with the Czech constitution. Klaus's concern was that the Charter could open the possibility of legal contests of the Beneš Decrees that had expelled the Germans and confiscated their property after the Second World War. Klaus signed the Charter, in October 2009, and the EU agreed to approve the opt-out as part of a future treaty.

94. Václav Klaus, “Z rozhovoru o Lisabonské smlouvě,” Mladá fronta Dnes, November 29, 2008, in Klaus, Rok šestý, 410.

95. In November 2008, Klaus privately met Ganley, after having concluded a state visit to Ireland. They publically announced their opposition to the Treaty of Lisbon, and the Irish government accused Klaus of having interfered in Irish political affairs.

96. Václav Klaus, “Zápis z přijetí členů konference předsedů Evropského parlamentu,” December 5, 2008, in Klaus, Rok šestý, 335.

97. Klaus, “Zápis z přijetí členů konference předsedů Evropského parlamentu,” 337.

98. Klaus, “Zápis z přijetí členů konference předsedů Evropského parlamentu,” 229.

99. Václav Klaus, “Projev v Evropském parlamentu,” in Klaus, Rok sedmý, 68-69 and 70-71. 
100. Václav Klaus, “Co nám říká dnešek o budoucnosti Evropy?” February 19, 2009, in Klaus, Rok sedmý, 76.

101. Canvassers began their work June 8 , immediately after the EP elections, and they completed it on June 15 , immediately after the EP elections. CVVM, "Důvěra ústavním institucím a spokojenost s politickou situací v červnu 2009," July 8, 2009, 1, http://cvvm. soc.cas.cz/media/com_form2content/documents/c1/a3659/f3/100935s_pi90708.pdf.

102. The Social Democrats managed to get a no-confidence vote through the Czech Parliament in March 2009. A government of experts took office, and elections were to take place in October. A member of parliament challenged the decision for early elections, and the Constitutional Court found that it was illegal. The legislature changed the law, but to forestall another court case, the Social Democrats avoided another attempt at dissolving parliament, and regularly scheduled elections took place in the middle of 2010.

103. Václav Klaus, "Statement of President Václav Klaus on the Ratification of the Lisbon Treaty," October 9, 2009, http://www.klaus.cz/clanky/182.

104. Negotiations about the opt-out began in 2009 and continued until 2014, when the Czech government withdrew the opt-out request.

105. Václav Klaus, Kde začíná zitř̌ek (Prague: Euromedia Group, k.s.-Knižní klub, 2009), 184-205. The date Klaus put on the final chapter was October 1, 2009.

106. Václav Klaus, “Prohlášení k rozhodnutí Ústavního soudu ze dne 3. listopadu 2009,” November 3, 2009, in Klaus, Rok sedmý, 117. The cabinet of Prime Minister Bohuslav Sobotka (born 1971), which took office in January 2014, rescinded the opt-out for the Charter of Fundamental Rights.

107. Pehe, Klaus, 268. In his chapter on the Lisbon Treaty, Pehe describes Klaus's political maneuvering to defeat the treaty. See also Kopeček, Fenomén, 224-228.

108. The calculations are based on CVVM, “Obyvatelé ČR a Lisabonská smlouva v říjnu 2009,” November 20, 2009, Table 7, http://cvvm.soc.cas.cz/media/com_form2content/documents/c1/a3693/f3/100969s_pm91120.pdf.

109. Klaus reiterated this opinion several times, but his most concise explanation is in “Kdy zkrachuje eurozóna?" Ekonom, April, 23 2010, in Klaus, Rok osmý, 55-59. He mentioned it again at a speech on December 8, 2010, that is reprinted in Klaus, Rokosmý, 108.

110. Václav Klaus, “Otazníky nad formu dnešní evropské integrace: berlínský projev,” Mladá fronta Dnes, April 30, 2010 (the speech originally was on April 29, 2010), in Klaus, Rok osmý, 64.

111. Václav Klaus, “Úryvky z rozhovoru pro týdeník Euro,” Euro, May 3, 2010, in Klaus, Rok osmý, 70.

112. Václav Klaus, "Úryvky z rozhovoru pro časopis Týden o volbách do Poslanecké sněmovny a o problémech eurozóny,” Týden, May 10, 2010, in Klaus, Rok osmý, 127-128.

113. Václav Klaus, "Úvaha o budoucích posunech ekonomické síly ve světě," speech during a conference of the Washington Institute of International Finance, in Stresa, Italy, Hospodářské noviny, July 2, 2010, in Klaus, Rok osmý, 80.

114. Václav Klaus, "Předmluva ke knize Autoři CEPu o euru," originally a speech at the seminar "Authors of the CEPu about the Euro," September 27, 2010, in Klaus, Rok osmý, 92.

115. Václav Klaus, "Evropa, pomalu končící krize a portřeba nově zformulovat argumenty pro kapitalismus," speech at the Transatlantic Leaders' Forum, Johns Hopkins University, September 22, 2010, Hospodářské noviny, September 23, 2010, in Klaus, Rok osmý, 88.

116. CVVM, Sociologický ústav AV ČR, v.v.i.., “Hodnocení působení Václava Klause v prezidentském úřadě,” April 15, 2013 (note the incorrect year of 2012 on the report), Table 1, http://cvvm.soc.cas.cz/. 
117. In these years, Klaus continued to display his Euroskepticism in articles, interviews, and statements, most of which are available in his Rok devátý and Rok desátý.

118. Ben Quinn, “Czech Leader Vaclav Klaus Caught Stealing Pen on Chile Trip,” The Guardian, April 12, 2011, “ABC News, “Czech President Caught Stealing Pen,” Youtube video, 01.42, posted April 14, 2011, https://www.youtube.com/watch?v= dMoaJCd6qMk.

119. Leos Rousek, “Czech President's Adviser Makes Headlines with Anti-Gay Remarks,” Wall Street Journal, August 5, 2011, http://blogs.wsj.com/emergingeurope/2011/08/05/czech-presidents-adviser-makes-headlines-with-anti-gay-remarks/; and Václav Klaus, "Prohlášení prezidenta republiky k dalšímu exemplárnímu útoku na svobodu slova," press release of August 5, 2011, http://www.klaus.cz/clanky/2896.

120. Václav Klaus, "Rozhovor prezidenta republiky pro deník Právo,” Právo, August 27, 2011, http://www.klaus.cz/clanky/2912. Klaus previously had been critical of Greece, and in May 2010, he said that Greece never should have entered the eurozone. Václav Klaus, "Úryvky z rozhovoru pro časopis Týden o problémech eurozony," Týden, May 10, 2010, in Klaus, Rok osmý, 71.

121. Václav Klaus, "Evropa budoucnost má, ale ne př́iliš růžovou,” Jihotyrolské hospodářské fórum, Brixen, March 18, 2011, and Lidové noviny, March 19, 2011, in Klaus, Rok devátý, 58.

122. Václav Klaus, "Rozhovor pro magazín Forbes o evropské krizi,” November 3, 2011, in Klaus, Rok devátý, 81 (first quotation), 82 (second quotation), and 83 (third quotation).

123. Václav Klaus, Evropská integrace bez iluzí (Prague: Euromedia Group k.s.-Knižní klub, 2011). It appears in English as Europe: The Shattering of Illusions, trans. Ondřej Hejma (London and New Delhi: Bloomsbury Publishing Plc, 2012); see, for example, 94 and 143 in the English version.

124. Václav Klaus, "Vystoupení na křtu knihy Evropská integrace bez iluzi,” November 23, 2011, in Klaus, Rok devátý, 91.

125. Klaus gave his reasons for opposing the treaty in "Odpověd Lidovým novinám na otázky týkající se Smlouvy o fiskální unii," Lidové noviny, January 20, 2012; "Odpověd na otázku českých médií o Evropské fiskální smlouvě a postoji českého preméra k ní," January 31, 2012; and "Rozhovor pro deník Právo o postoji České republiky k připravované Evropské fiskální smlouvě," Právo, February 1, 2012, in Rok desátý, 54-60. When he became president, Zeman indicated his willingness to sign the treaty, and in January 2014, after Sobotka had become the prime minister, the government initiated negotiations to join the Fiscal Pact. The pertinent legislation associated with the treaty received final approval in October 2016, but a related constitutional amendment is pending.

126. The Czech Republic's participation was not required, since it was not in the eurozone. Klaus's successor, Zeman, signed the treaty on April 3, 2013.

127. For Klaus's defense of the amnesty, see Marek Loužek, ed., Spor o amnestii, Publication 1/2013 (Prague: Institut Václava Klause and Centrum pro ekonomiku a politiku, 2013).

128. Václav Klaus, "Posun, který nastal v Maastrichtu” and “Referendum o 'evropské ústavě' ve Francii,” My, Evropa a svět (Prague: Nakladatelství FRAGMENT, s.r.o., 2013), 66-70 and 112-122.

129. SE $2015 / 84$ was the most recent survey available, as of early July 2016 . Negative indicators in trust, image, and direction for the EU as a whole also increased in the autumn of 2015.

130. The $\mathrm{r}$-squared is 0.344283 . The $\mathrm{p}$-value is 0.008278 , with the result being significant at $\mathrm{p}<0.05$.

131. For the correlation between the ESI and EI, r-squared is 0.402211 . The $p$-value is 0.003557 , with the result being significant at $\mathrm{p}$ $<0.05$.

132. For the correlation between the ESI and EI in this shorter period, r-squared is 0.26871 . The p-value for this small sample is 0.188504 , but the result is not significant at $\mathrm{p}<0.05$. 
133. See references to Eibl, Gregor, and Macková, “O čem a jak hovořil Václav Klaus," in the section of this study titled "Klaus's Criticisms of the EU and Czech Euroskepticism-More than a Coincidence."

134. The migration crisis, which led to a spike in Euroskepticism throughout Europe, did not become an issue until 2015.

135. As Klaus's successor, Zeman also has had his share of embarrassments that have harmed his image, and a comparative study of the two presidents' unpopular stances and faux pas would provide an important glimpse into Czech politics.

136. In the summer of 2016, Zeman suggested that the Czech Republic hold a referendum on whether it should remain in the EU and NATO, in order to give the people a voice in these matters, even though he supported the Czech Republic's continued membership in both organizations. Český rozhlas, "Zeman je pro referendum o českém odchodu z EU a NATO, hlasoval by ale proti," June 30, 2016, http://www.rozhlas.cz/zpravy/politika/_zprava/zeman-je-pro-referendum-o-ceskem-odchodu-z-eu-a-nato-hlasoval-by-ale-proti-1629150.

137. A February 2014 survey by the Czech firm Median revealed that 53 percent of Czechs viewed the EU rather negatively or very negatively, and only 37 percent viewed it very positively or relatively positively ( 26 percent were neutral, and 2 percent did not know). These results show a greater degree of negativity than the ES poll for roughly the same time period, but the questions were different. Unfortunately, there are no additional published polls from Median to enable any sort of comparison. See Median, "Evropská unie očima Čechů a Slováků: Bleskový výzkum v ČR a SR,” February 24, 2014, "Vliv členství v EU obecně," http://img.ct24.cz/multimedia/documents/55/5499/549861.pdf.

138. The higher EI for the second half of 2015 and the first half of 2016 may have been a result of both the migrant crisis and Brexit.

139. A news article, published when Klaus left office, weighed the opinions of a number of Czech political scientists about the future of Euroskepticism in the Czech Republic. They noted that, since Klaus did not create suspicions about the EU singlehandedly, the tendency will persist. "Politologové: S odchodem Klause český euroskepticismus nezmizí," Euractiv.cz, March 8, 2013, http://www.euractiv.cz/cr-v-evropske-unii/clanek/politologove-s-odchodem-klause-cesky-euroskepticismus-nezmizi-eu010665\#sthash.4OEVuK1Z.dpuf.

140. Václav Klaus et al., Česká republika na rozcestí-Čas rozhodnutí (Prague: Nakladatelství FRAGMENT, s.r.o., 2013), 222-225. Shortly after leaving office, Klaus announced that he had accepted a position as a distinguished senior fellow at the Cato Institute, located in Washington, DC. That association ended, on September 1, 2014, according to two unnamed sources at the Cato Institute, because Klaus had defended Russia's interests in Ukraine. See James Kirchick, "Vaclav Klaus, Libertarian Hero, Has His Wings Clipped by Cato Institute," The Daily Beast, December 22, 2014, http://www.thedailybeast.com/articles/2014/12/22/vaclav-klauslibertarian-hero-has-his-wings-clipped-by-cato-institute.html; and mlb [Michal Bělka], "Institut Cato se rozešel s Klausem: 'Mistr svobody' moc bránil Putina," iDNES.cz, December 22, 2014, http://zpravy.idnes.cz/cato-institute-konci-spolupraci-s-klausem-fj2/zahranicni.aspx?c=A141222_170538_zahranicni_mlb (the article cites The Daily Beast as its source). In Prague, Klaus continued to head his Václav Klaus Institute (http://www.institutvk.cz/) and his CEPu think tanks.

141. Václav Klaus, “Je šance vrátit Evropu zpět ke svobodě?” contribution to a Festschrift for Robert Nef (born 1942), April 4, 2012, in Klaus, Rok Desátý, 65.

142. Zeman's remark is at "Politici nesouhlasí s návrhem Klause, aby Česko vystoupilo z EU," Radio Praha, October 3, 2013, http://www.radio.cz/cz/rubrika/zpravy/zpravy-2013-10-03.

143. ČTK, "Klaus: Nejdůležitější mé politické období bylo po listopadu 1989," ČTK České noviny, June 16, 2016, http://www.ceskenoviny.cz/zpravy/klaus-nejdulezitejsi-me-politicke-obdobi-bylo-po-listopadu-1989/1362179, also available as "Václav Klaus pro ČTK při př́ležitosti svých 75. narozenin," at http://www.klaus.cz/clanky/3947; and ČTK, iDNES.cz, "Nastal čas Alternativy pro Evropu, míní Klaus. Chce vyvážit ‘europeismus,"” iDNES.cz, June 16, 2016, http://zpravy.idnes.cz/vaclav-klausalternativa-pro-evropu-d78-/domaci.aspx?c=A160616_154128_domaci_ane. 
144. In the interview, Klaus stated that Brexit would not strengthen the radical right. When the moderator asked Klaus about the impact of Brexit on the Czech economy, Klaus answered "zero, zero, zero" and that "absolutely nothing" will happen. He remarked that claims to the contrary are merely scare tactics. He further noted that, even when the division of Czechoslovakia occurred, "the next day absolutely nothing [unusual] happened." Michael Rozsypal (interviewer) and Jana Trpišovská, "Václav Klaus: Dnes je úžasný den, brexit nás zachraňuje od bruselského monstra,” Český rozhlas Radiožurnál, June 24, 2016, http://www.rozhlas.cz/ radiozurnal/zajimavosti/_zprava/vaclav-klaus-dnes-je-uzasny-den-brexit-nas-zachranuje-od-bruselskeho-monstra--1626864.

145. ČTK, "Nevěříme EU? Může za to euroskeptik Klaus, říká Sobotka,” in Aktuálně.cz, November 4, 2014 , http://zpravy.aktualne.cz/domaci/neverime-eu-muze-za-to-euroskeptik-klaus-rika-sobotka/r 887ae760c1a411e388a00025900fea04/.

146. Amelia Hadfield and Silviu Piros, "Rogue Warrior or Eurosceptic Irritant? Mr. Klaus' Adventures in Euroland,” at http://www.ies.be/node/1409. The Czech version is "Samotářský válečník, nebo Euroskeptický rýpal? Klausova dobrodružství v eurosvětě," Hosodářské noviny, October 24, 2014, http://ihned.cz/?m=authors\&person[id]=17153490\&article[aut_id]=17153490. 